\title{
Clear Liquor Scrubbing with Anhydrite Production
}

Final Report

Contract DE-AC22-95PC95253

August 1998

Prepared by

Radian International

8501 North Mopac Blvd.

Austin, TX 78759

Project Manager

O.W. Hargrove, Jr.

Authors

T.R. Carey

R.C. Skarupa

Prepared for

Department of Energy

Federal Energy Technology Center

626 Cochran Mill Road

Pittsburgh, PA 15236 



\section{CONTENTS}

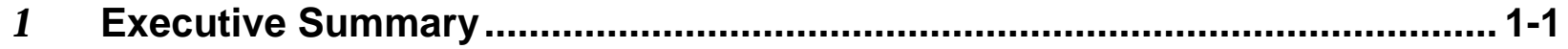

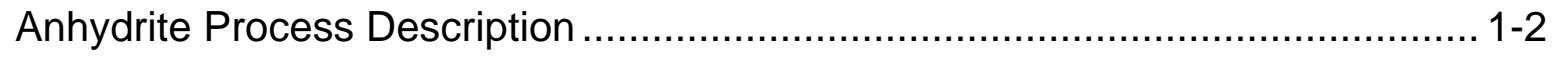

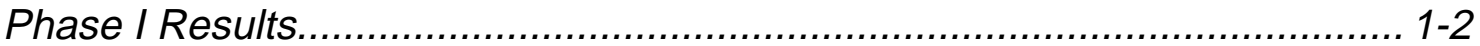

Laboratory-Scale Test Results ...................................................... 1-2

Market Study Results ................................................................ 1-3

Pilot-Scale Testing Results ........................................................... 1-3

Unresolved Technical Issues................................................................. 1-3

Process Control............................................................................. 1-3

Optimization of Process Conditions..................................................... 1-4

Demonstrate the Anhydrite Production over an Extended Period of

Time .................................................................................................. 1-4

Production of Larger Quantities of Anhydrite Powder ............................. 1-4

Commercialization of the Process............................................................ 1-4

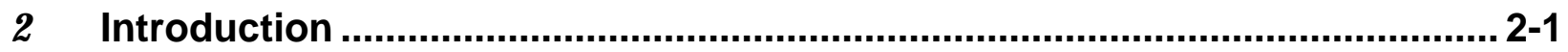

Project Overview ........................................................................................ 2-1

DOE Purpose and Objectives............................................................... 2-1

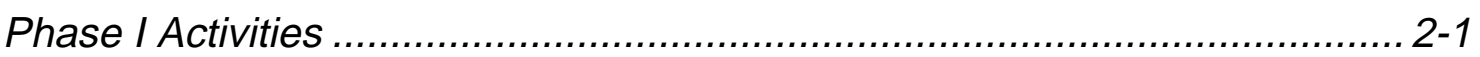

Future Development Needs .................................................................. 2-2

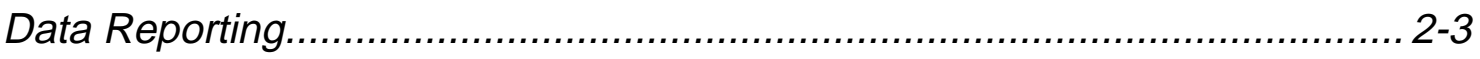

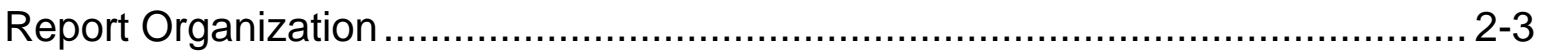

3 Summary of Results and Conclusions........................................................... 3-1

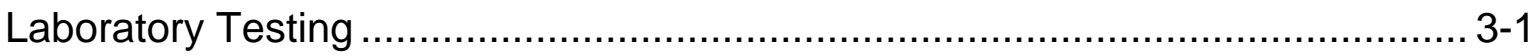

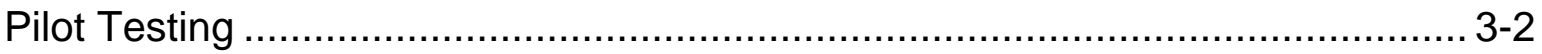

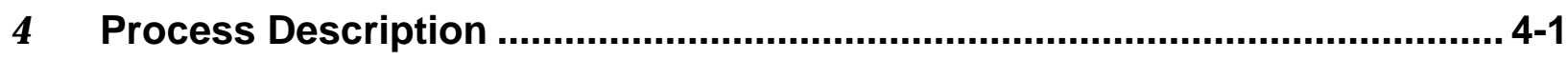

Clear Liquor Scrubbing Process .............................................................. 4-2

Chloride Removal Process.......................................................................... 4-2

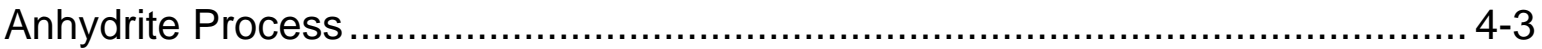




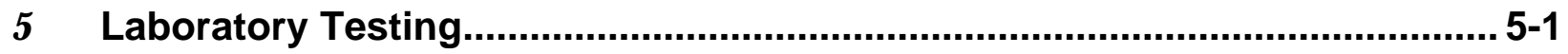

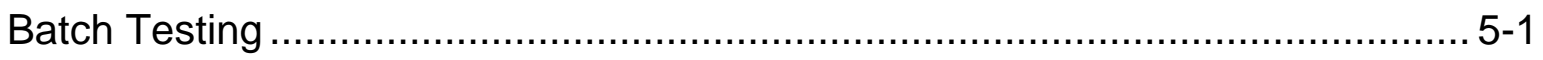

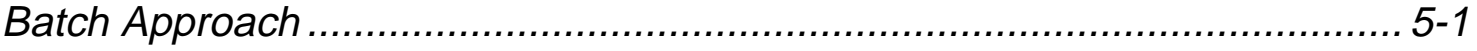

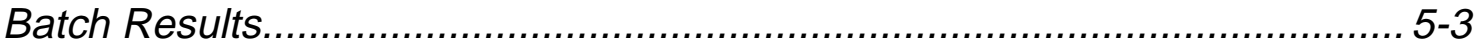

Effect of Temperature..................................................................... 5-3

Effect of Solution Strength and Composition......................................... 5-5

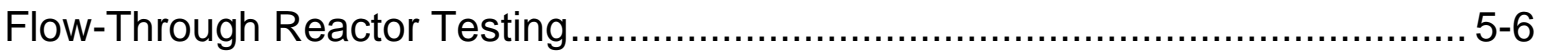

Flow-Through Test Approach ......................................................... 5-6

Flow-Through Test Results.............................................................. 5-8

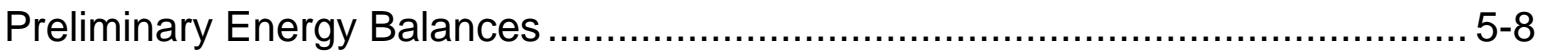

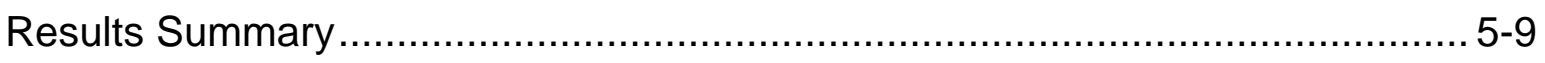

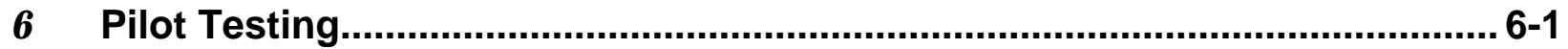

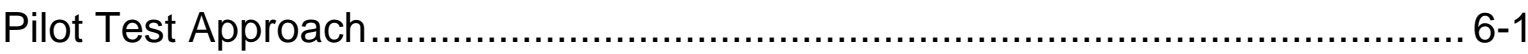

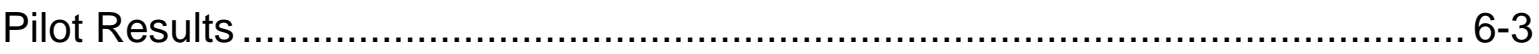

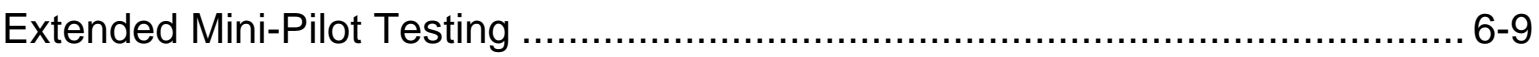

Chloride Removal Process Testing ...................................................... 6-10

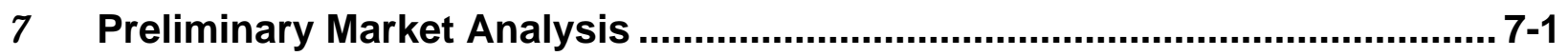

Comparison with Dutch Anhydrite Process .................................................... 7-1

Anhydrite Properties for Self-Leveling Floors............................................... 7-2

Requirements of Anhydrite to Penetrate the Self-Leveling Floor Market in

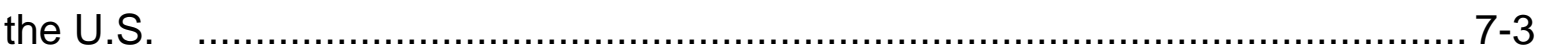

Potential for Use of Calcium Sulfate Anhydrite as a Synthetic Aggregate ........... 7-3

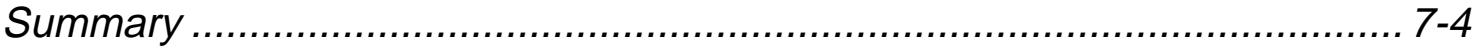

Aggregate Production and Use in the United States ................................ 7-4

Contact with Center for Aggregate Research .......................................... 7-5

Contact with Gulf States Materials.......................................................... 7-5

Preliminary Economic Study ..............................................................

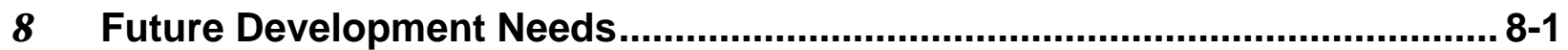

Lab-Scale Activities............................................................................. 8-1

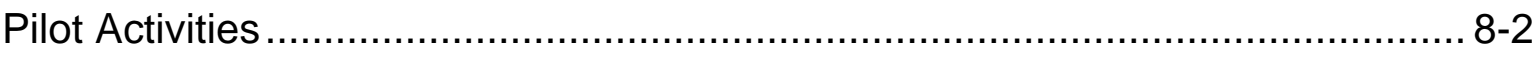

Commercialization Activities ..................................................................... 8-3

Appendix A Letters from Interested Companies

Appendix B Anhydrite Operations and Results Summary 


\section{LIST OF FIGURES}

Figure 4-1. Clear Liquor Scrubbing with Anhydrite Production ................................ 4-1

Figure 4-2. Calcium Sulfate Solubility Data ............................................................. 4-5

Figure 5-1. Lab-Scale Batch Reactor ............................................................ 5-2

Figure 5-2. Effect of Temperature on Batch Precipitation Rate................................... 5-4

Figure 5-3. Effect Solution Strength on Anhydrite Precipitation Rate ( $\mathrm{NaCl}$ Solutions) .....................................................................................

Figure 5-4. Effect of Sulfate Concentration on Anhydrite Precipitation Rate................ 5-5

Figure 5-5. Flow-Through Crystallizer .......................................................... 5-7

Figure 6-1. ECTC Flow Configuration for Anhydrite Test Block ................................ 6-2

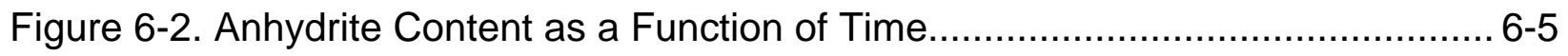

Figure 6-3. Period 1 (February 3) XRD/SEM Results (Gypsum) .............................. 6-5

Figure 6-4. Period 2 (2/10/97) XRD/SEM Results (Gypsum and Anhydrite) ................ 6-6

Figure 6-5. Period 3 (3/5/97) XRD/SEM Results (Gypsum and Anhydrite) .................. 6-7

Figure 6-6. Period 4 (e/14/97) XRD/SEM Results (Gypsum and Anhydrite) ................ 6-8

Figure 6-7. Effect of Lime Injection on HCI Removal ............................................ 6-12 


\section{LIST OF TABLES}

Table 5-1. Anhydrite Formation Lab-Scale Batch Test Conditions ........................... 5-2

Table 5-2. Anhydrite Formation Flow-Through Test Conditions................................. 5-7

Table 6-1. Variables and Ranges of Interest in Anhydrite Development Pilot Work .... 6-2

Table 7-1. Anhydrite Project Capital Cost Estimate ….......................................... 7-6

Table 7-2. Anhydrite Process Operating Cost Estimate.......................................... 7-6 


\section{1}

\section{EXECUTIVE SUMMARY}

This project is funded by the U.S. Department of Energy's Federal Energy Technology Center (DOE/FETC) under a cost-sharing PRDA with Radian International. The Electric Power Research Institute (EPRI) is providing co-funding and technical oversight. The project is part of FETC's Advanced Power Systems Program, whose mission is to accelerate the commercialization of affordable, high-efficiency, low emission, coalfueled electric generating technologies.

This project was submitted in response to Area 4 of DOE's Mega-PRDA: Advanced High-Performance $\mathrm{SO}_{2}$ Control Concepts. The goals of this research area are to develop advanced flue gas desulfurization (FGD) processes that achieve greater than $99 \% \mathrm{SO}_{2}$ removal efficiency, are $25 \%$ cheaper than commercial FGD systems, and provide a valuable byproduct that will be recycled rather than disposed. Area 4 also included the development of a byproduct process that could be added to FGD systems to produce high value byproducts for reuse rather than disposal.

A process concept-Clear Liquor Scrubbing with Anhydrite Production-was proposed and accepted by FETC as a Phase I project in its Mega-PRDA program. The project integrates three process operations-chloride control upstream of the FGD system, a clear liquor process for enhanced $\mathrm{SO}_{2}$ removal performance, and production of anhydrite (anhydrous calcium sulfate) rather than calcium sulfite or gypsum (calcium sulfate dihydrate). The CLS/Anhydrite process is an advanced FGD process designed to remove greater than $99 \%$ of the $\mathrm{SO}_{2}$ from flue gas, to avoid reliability problems associated with many existing FGD systems, and to produce a reusable byproductanhydrous calcium sulfate (anhydrite). Substantial cost reduction and greater byproduct marketing flexibility are projected for this process.

The project, as originally proposed, was to include pilot-scale testing of the chloride removal and Clear Liquor Scrubbing (CLS) processes, and lab-scale testing of anhydrite production followed by pilot-scale proof-of-concept testing of the anhydrite process. After consultation with DOE, Phase I of the project was focused on anhydrite production almost entirely. There are several reasons for this shift in focus:

- The anhydrite process was the least developed of the three process operations;

- The anhydrite process could have widespread applicability for the U.S. utility industry;

- Recent technological advances have made slurry processes less costly, thus reducing the cost-savings associated with a clear liquor process; 
- EPRI determined that U.S. utilities were most interested in the alternative byproduct part of our process concept; and

- The anhydrite production part of the overall process concept could potentially be commercialized most quickly.

Phase I was then modified to include three research areas: laboratory development to prove the proposed anhydrite chemistry; a market study to determine the potential for a U.S. anhydrite market; and 4-MW pilot-scale proof-of-concept testing at EPRI's Environmental Control Technology Center (ECTC) to demonstrate that the anhydrite process could be successfully coupled with an existing FGD system.

\section{Anhydrite Process Description}

The anhydrite process can be added to an existing FGD system, and uses the waste calcium sulfite as feed stock. The sulfite solids are fed to a reactor where they are first dissolved under acidic conditions and then oxidized to sulfate using compressed air. The heat of reaction from the oxidation step maintains the reactor temperature at the desired value without auxiliary heating. At this temperature and in a solution of high ionic strength, which is provided by sodium or magnesium salts, calcium sulfate anhydride (anhydrite) can be precipitated. To achieve this product, a surface area control mechanism must be implemented. The anhydrite solids are washed to recover the sodium and/or magnesium salts, then partially dried on a vacuum belt filter. Two different byproducts can be produced, depending on the treatment of the filter product. If the filter product is immediately sent to a thermal dryer, a free-flowing, reactive anhydrite powder can be produced. If the filter product is instead left in a damp condition, it will rapidly rehydrate and set up to form a hard gypsum suitable for use as an aggregate material.

\section{Phase I Results}

\section{Laboratory-Scale Test Results}

Both batch and flow-through reactor experiments were conducted to determine the effects of important process variables-ionic strength, liquor temperature, reactor residence time, and liquor composition — on the growth rate and purity of anhydrite were investigated. Conditions were tested where $100 \%$ anhydrite was produced, and anhydrite precipitation rates were measured that are equivalent to gypsum precipitation rates at typical FGD conditions. These results suggested that high purity anhydrite could be produced, and that reactor tanks of an economically viable size could be used in the production of anhydrite at the commercial scale. 


\section{Market Study Results}

Based on these successful lab results, a market study was conducted to determine the potential for developing U.S. anhydrite markets. Two potential markets were identified. One is a potentially high value use for the dried powder, as a screed material for selfleveling floors, although a U.S. market would have to be developed. The other is as a synthetic crushed stone aggregate for road base and other construction applications. This represents a potentially huge market for the anhydrite product, although at a relatively low dollar value.

\section{Pilot-Scale Testing Results}

The pilot-scale testing was conducted at the EPRI ECTC, using their 4-MW pilot wet scrubber to generate a waste calcium sulfite slurry. Existing equipment at the test facility that was not optimized for anhydrite production was used. Key variables investigated included reactor slurry temperature and residence time, ionic strength (using either sodium or magnesium salts to raise ionic strength levels), oxidation air rates, feed slurry weight percent solids, surface area control mechanisms, and others.

Although there are several periods where the percentage of anhydrite production was low (gypsum is typically produced if optimum conditions for anhydrite production are not maintained), there were two periods where anhydrite of greater than $90 \%$ purity was produced. An important finding of this pilot-scale testing was that anhydrite could only be made reliably at high purity levels if a surface area control mechanism was used to aid precipitation. The anhydrite produced was also found to be as reactive as commercially available anhydrite products.

\section{Unresolved Technical Issues}

Although the Phase I research results are very encouraging, a number of technical issues remain to be addressed. These are briefly summarized below.

\section{Process Control}

Although anhydrite is the thermodynamically preferred product at the higher slurry temperatures at which the anhydrite reactor operates, kinetics favor production of gypsum. To produce anhydrite, the slurry composition must be maintained below the gypsum saturation level to eliminate the possibility of gypsum precipitation, but process economics favor maintaining calcium and sulfate concentrations as near the gypsum saturation level as possible. Current methods for calculating gypsum relative are not accurate at the high ionic strength levels of this process. More data are required to improve the accuracy of these computational models to allow optimal process control. 


\section{Optimization of Process Conditions}

While conditions were discovered in pilot studies conducted during Phase I that allowed the successful production of anhydrite, these conditions are likely not the optimum ones. A better set of operating parameters that will minimize the operating costs for anhydrite production must be determined.

\section{Demonstrate the Anhydrite Production over an Extended Period of Time}

Although the Phase I results demonstrated the ability to produce a high purity ( $>90 \%$ ) anhydrite product, the longest run at these conditions during Phase I was approximately three days. After process control capabilities are improved and conditions are optimized as described above, the process must be demonstrated to produce high purity anhydrite over a period of several weeks or greater.

\section{Production of Larger Quantities of Anhydrite Powder}

The potentially high value product from this process is a reactive anhydrite powder that can be used in self-leveling floor applications. To produce this reactive powder, the anhydrite slurry leaving the reactor must be washed with hot water to remove entrained salts, then completely dried. In the Phase I pilot-scale proof-of-concept tests, equipment was not available to wash or thermally dry the product at the same scale. Smaller quantities at the laboratory scale could be washed and dried to verify that a reactive powder could be produced, but it remains to be demonstrated that hot water washing and thermal drying can be integrated with the reactor to produce commercial quantities of the high-value reactive powder.

\section{Commercialization of the Process}

The results from the integrated pilot-scale testing will provide data that can be used to commercialize the anhydrite process. The pilot results will produce optimum operating conditions for the reactor, wash system, and dryer, as well as data that can be used to size full-scale equipment.

Commercialization of the anhydrite process will require that three parties are brought together: an interested U.S. electric utility with an existing or new sulfite-producing FGD system, an organization that can design, construct, and potentially operate the add-on anhydrite process, and an end user that will agree to purchase the product at an economically viable price. Further pilot-scale testing will be required before a full-scale process is designed and built. The pilot-scale testing would verify for the utility industry that the anhydrite process can be successfully implemented, provide data for the full-scale design, and produce anhydrite in sufficient quantities for test applications. This pilot work was proposed for Phase II of this PRDA project. 
Executive Summary 



\section{2}

\section{INTRODUCTION}

\section{Project Overview}

\section{DOE Purpose and Objectives}

This project is funded by the U.S. Department of Energy's Federal Energy Technology Center (DOE/FETC) under a cost-sharing PRDA with Radian International. EPRI is providing co-funding and technical oversight. The project is part of FETC's Advanced Power Systems Program, whose mission is to accelerate the commercialization of affordable, high-efficiency, low emission, coal-fueled electric generating technologies.

This project was submitted in response to Area 4 of DOE's Mega-PRDA: Advanced High-Performance $\mathrm{SO}_{2}$ Control Concepts. The goals of this research area are to develop advanced flue gas desulfurization (FGD) processes that achieve greater than $99 \% \mathrm{SO}_{2}$ removal efficiency, are $25 \%$ cheaper than commercial FGD systems, and provide a valuable byproduct that will be recycled rather than disposed. Area 4 also included the development of a byproduct process that could be added to FGD systems to produce high value byproducts for reuse rather than disposal.

A process concept-Clear Liquor Scrubbing with Anhydrite Production-was proposed and accepted by FETC as a Phase I project in its Mega-PRDA program. The project integrates three process operations-chloride control upstream of the FGD system, a clear liquor process for enhanced $\mathrm{SO}_{2}$ removal performance, and production of anhydrite (anhydrous calcium sulfate) rather than calcium sulfite or gypsum (calcium sulfate dihydrate). The CLS/Anhydrite process is an advanced FGD process designed to remove greater than $99 \%$ of the $\mathrm{SO}_{2}$ from flue gas, to avoid reliability problems associated with many existing FGD systems, and to produce a reusable byproductanhydrous calcium sulfate (anhydrite). Substantial cost reduction and greater byproduct marketing flexibility are projected for this process.

\section{Phase I Activities}

After consultation with DOE, Phase I of the PRDA was focused on anhydrite production almost entirely. This was done because of the small scale of development of the anhydrite process before this project, progress in producing reactive anhydrite from solution during both laboratory testing and preliminary proof-of-concept testing at the 
$4 \mathrm{MW}$ pilot scale, and more near-term interest in an alternative byproduct by the utility industry. A few tests were conducted with the chloride control concept as well.

During Phase I, anhydrite process development activities proceeded in three major areas:

- Laboratory development to prove the proposed anhydrite chemistry was feasible;

- A market feasibility study to determine if reasonable markets could be developed if the process was proven successful technically; and

- 4-MW pilot-scale proof of concept testing to demonstrate that the anhydrite process could be successfully coupled with an FGD system producing calcium sulfite sludge.

The lab-scale studies showed that anhydrite could be produced from simulated FGD solutions at elevated temperatures and ionic strengths. Flow-through reactor tests confirmed batch test results that indicated anhydrite could be produced at rates equivalent to gypsum production rates of current commercial processes. This means that anhydrite equipment should be of an economical size if other aspects, such as sulfite oxidation and control of anhydrite surface area, prove to be feasible.

The market analysis indicates two major potential markets for FGD anhydrite including self-leveling floor screeds and aggregate in aggregate poor areas. Anhydrite is being used in the self-leveling floor industry in Europe with more than 136,000 metric tons $(150,000$ U.S. tons) of anhydrite used in 1996. This market will have to be developed in the U.S. Currently, anhydrite is used as aggregate in the Houston area; this could be a much larger, though lower-value market for FGD anhydrite.

Pilot activities proved the FGD anhydrite concept to be successful in both sodium and magnesium rich slurries. Although the equipment available was not optimum for anhydrite production, reactive anhydrite was produced during several week-long tests. The major finding from the Phase I testing was that the anhydrite surface area must be controlled by external means. Without this external control mechanism, anhydrite crystals will form, but product properties cannot be controlled and gypsum will also be co-produced reducing the value and usefulness of the product. Other process variables, including temperature and ionic strength, are known to be important but could not be optimized during Phase I activities due to time and budget constraints.

\section{Future Development Needs}

Although the anhydrite process proof-of-concept testing was successful in Phase I, there are many requirements to be fulfilled before the process can be demonstrated at full scale and then commercialized. First, the process must be optimized and control procedures established so that high quality anhydrite can be produced consistently and more accurate economics can be determined. This will include design and installation of an appropriately sized anhydrite reactor based on results from Phase I. Also, the 
process must be set up to wash the product with hot water and then dry it so that larger quantities of the product can be produced for testing by the interested manufacturing companies.

\section{Data Reporting}

At the beginning of this project, the Radian/EPRI team requested that certain types of data from the project be protected as proprietary and not subject to publication by DOE. These protected data include detailed design information concerning the anhydrite crystallizer, including dissolved ion concentrations and reactor temperatures.

Consequently, this report has been written so that these two values are not specifically reported. Where appropriate, the ranges of variation of these parameters in individual test matrices are reported, but the actual values are not.

\section{Report Organization}

The remainder of this report is organized in the following sections:

- Section 3-Summary of Results and Conclusions

- Section 4-Process Description

- Section 5-Laboratory Testing

- Section 6-Pilot Testing

- Section 7-Preliminary Market Analysis

- Section 8-Future Development Needs 



\section{3}

\section{SUMMARY OF RESULTS AND CONCLUSIONS}

The project was originally proposed as an integration of three separate processes including $\mathrm{HCl}$ removal, clear liquor scrubbing, and anhydrite production. As Phase I evolved, the effort was focused on anhydrite production because:

- Its technology was immature compared to the others;

- Utilities are more interested in byproduct reuse over the near term;

- The anhydrite process can be retrofit to existing FGD systems, widening its applicability; and

- The anhydrite process has the greatest chance of being commercialized over the next few years.

Development of the anhydrite process was pursued on three levels during Phase Ilaboratory testing, pilot testing, and preliminary market analysis. This section is organized according to these topics.

\section{Laboratory Testing}

Both batch tests and liquid flow-through, batch solids tests were conducted in the laboratory in Phase I. Results and conclusions from these tests are summarized below:

- Anhydrite precipitation rates equivalent to typical gypsum precipitation rates at FGD forced oxidation conditions were achieved in both the batch and flow-through experiments. This means that the reaction tank for anhydrite will be of a size similar to current reaction vessels (economically competitive).

- To achieve the higher precipitation rates, reaction temperatures must be higher than typical FGD slurry temperatures. A preliminary energy balance calculation shows that temperatures in the range tested can be achieved in the anhydrite reactor through the heat of reaction, without external heat added and without heat exchangers.

- Higher ionic strength solutions (higher concentrations of total dissolved solids) increase the anhydrite precipitation rate.

- High concentrations of calcium relative to sulfate dramatically slow the anhydrite precipitation rate. (This situation might be encountered with a coal of relatively high chloride content such that the flue gas contained high concentrations of $\mathrm{HCl}$. However, the chloride removal process included in this PRDA or addition of 
sodium or magnesium would raise the sulfate-to-calcium ratio into the correct range.)

Based on the successful production of anhydrite in the laboratory, it was recommended that further testing be conducted at the ECTC. The next step in the development of the anhydrite process was integration of the calcium sulfite dissolution and sulfite oxidation reactions with anhydrite formation. This was most easily accomplished at the ECTC because:

- It was designed to operate continuously and was appropriately instrumented and staffed.

- Steady-state conditions, which determine solids properties, could be more efficiently maintained in a process with instrumentation and staff set up for continuous operation.

- The pilot-scale equipment is much closer in size to full-scale equipment so the crystal size distributions measured there can be used to more accurately predict the product quality of a full-scale anhydrite process.

\section{Pilot Testing}

Phase I pilot testing was successful in proving that anhydrite can be successfully produced from FGD calcium sulfite slurry at atmospheric pressure. An understanding of important variable interactions was developed, but process and control optimization for the process remains as an objective for future testing. Important findings from Phase I Pilot work are:

- Anhydrite (anhydrous $\mathrm{CaSO}_{4}$ ) was formed at elevated temperature and ionic strength levels in the slurry fed to the reactor.

- Existing equipment configurations limited testing of all variables in Phase I. A compromise was made to use greater than desired reactor residence times in order to reduce the oxidation air requirements and the associated slurry cooling by evaporation. As a result the residence times employed were between 60 and 90 hours in Phase I, whereas it was desired to test residence times in the range of 10 to 30 hours.

- It was discovered that the anhydrite nucleation rate was not sufficient to generate the surface area required to maintain precipitation without increasing the relative saturation to the point that gypsum was formed. An external means for providing the required surface area was required.

- Reactive anhydrite was produced that reacted within 30 minutes to an hour to form a hardened mass. This mass continued to harden and was emptied from containers in a single piece for disposal. The product solids had to be collected in alcohol and dried to preserve the reactive properties for additional testing. Preliminary testing of the product identified the product as reactive anhydrite with properties similar to 
reactive anhydrite produced in Europe. Small sample size and budget limited product testing in Phase I.

A preliminary market analysis identified two potentially attractive markets for FGD anhydrite-in self-leveling floors and as construction aggregate:

- The self-leveling floor market is developing in Europe with the market expanding by 10 -fold in the Netherlands and Germany over the past 10 years. The FGD solution anhydrite process being developed has energy advantages over the European process and can produce a less expensive anhydrite product based on preliminary economics. A number of gypsum companies are evaluating the anhydrite produced in Phase I.

- The construction aggregate market was a 1.09 billion-metric ton (1.2 billion-U.S. ton) market in 1993, and hardened anhydrite should meet aggregate specifications. An anhydrite byproduct from hydrofluoric acid (HF) manufacture is currently being sold as aggregate in the Houston area.

Overall, proof-of-concept testing in Phase I is judged a success. Potential markets exist, but further production and testing is required. The process must be optimized and sufficient product generated for testing by end-users in order to evaluate the economics and ultimate use of the product. 

4

PROCESS DESCRIPTION

Figure 4-1 illustrates the basic flow diagram for the CLS/anhydrite process as originally conceived for this Mega-PRDA project. This figure includes incorporation of the alkali/humidification process for $\mathrm{HCl}$ reduction and the anhydrite production process. However, each of the three processes can be applied independently.

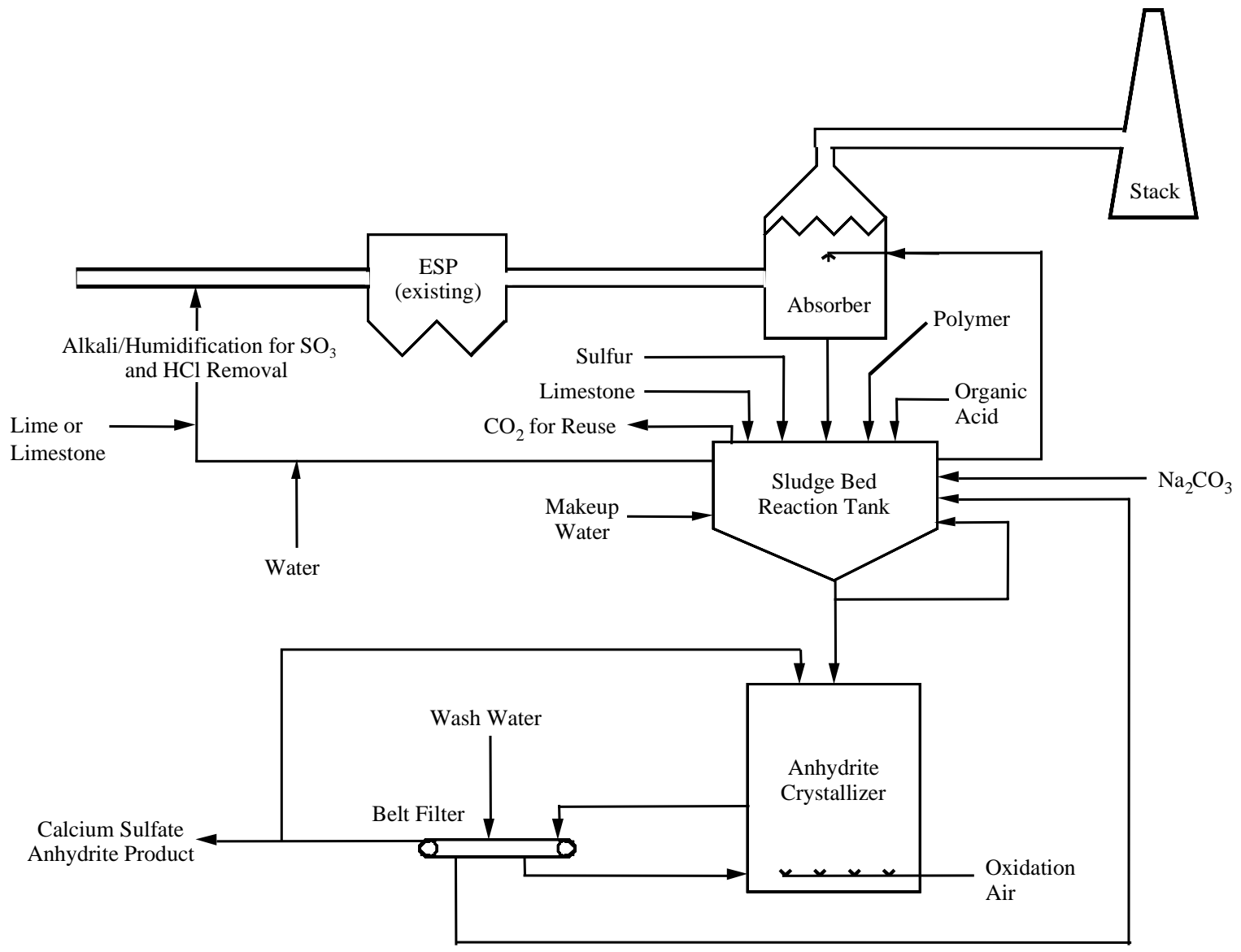

Figure 4-1. Clear Liquor Scrubbing with Anhydrite Production 


\section{Clear Liquor Scrubbing Process}

The basic CLS concept is to recirculate clear liquor that contains a buffer to provide a sufficient liquid-phase alkalinity to achieve the desired $\mathrm{SO}_{2}$ removal efficiency without the need for solid-phase alkalinity. The liquor then flows to a limestone reactor and solid-liquid separator that precipitates a calcium-sulfur solid and returns clear liquor to the scrubber. The CLS process can be operated as an inhibited-oxidation system (calcium sulfite production) or as a forced-oxidation system (gypsum production). Either of these two products can then be converted to anhydrite; however, the economics of the anhydrite process are more favorable if calcium sulfite is produced in the CLS system.

To be successful, the CLS process must generate solids that are easily dewatered at high rates so that the high volume of liquor passing through the regeneration system does not require large or expensive tanks and equipment. Other key aspects for the success of the process include low consumption rates of the buffer, low liquid-to-gas ratio (L/G) in the scrubber, and control of the chemistry to achieve good limestone utilization and low gypsum scaling potential. The CLS process had been developed during prior EPRI testing using the 0.4-MW mini-pilot system at EPRI's Environmental Control Technology Center (ECTC).

Based on the previous studies of the CLS process, several issues require further investigation. The first need is to verify the findings observed on the mini-pilot system on the pilot system that is 10 times larger. Full-scale design criteria need to be developed and refined at the 4-MW pilot-scale before a full-scale demonstration is attempted. Variables to be tested at the larger scale include residence time, $\mathrm{pH}$, suspended solids concentration, recycle ratio, and degree of agitation. In addition, the potential for combining the CLS process with the anhydrite process needs to be investigated. The high TDS concentration necessary for the anhydrite process could prove to have a negative effect on the calcium sulfite solids properties in the CLS process.

\section{Chloride Removal Process}

Maintaining a low chloride concentration in a FGD system has several potential benefits. Corrosion should be minimized at low concentrations that may allow the materials of construction to be cheaper. In limestone systems, the limestone utilization will generally be higher at low chloride concentrations. Finally, the scaling potential is reduced in the CLS process when chloride levels are reduced.

EPRI has examined a number of chloride control options including prescrubbing, tailend separation or concentration, and injection of scrubber blowdown into the flue gas. The first two options are relatively expensive and result in some wastewater streams. 
The last option has been tested with limited success, but chloride removal is limited by off-gassing of $\mathrm{HCl}$ in the process of drying the liquid.

The proposed chloride removal process involves injection of alkaline slurry upstream of an ESP or other particulate removal device. $\mathrm{HCl}$ in the flue gas reacts with the alkali to form a solid, which is dried by the flue gas and collected in the particulate removal device. EPRI has developed a similar process to react flue gas $\mathrm{SO}_{3}$ with alkali reagent to mitigate opacity problems and has completed considerable work on the effect of sorbent injection on $\mathrm{SO}_{2}$ removal.

\section{Anhydrite Process}

As shown in Figure 4-1, a process that produces anhydrous calcium sulfate (anhydrite) can be integrated with the CLS and chloride removal processes also included in this project. The anhydrite process could potentially be added to any conventional FGD system. The calcium sulfite solids are dissolved into a reaction tank containing a solution with elevated levels of a dissolved salt such as sodium or magnesium sulfate and the dissolved sulfite is subsequently oxidized with air. Since the oxidation of sulfite to sulfate is exothermic (releases energy) the solution temperature can be elevated without external heating. Potential advantages of crystallizing anhydrite rather than gypsum from solution include the following: energy savings over thermally dehydrating gypsum, producing a material of lesser specific volume than gypsum, potentially displacing gypsum in some commercial applications, and producing a material for different commercial applications than gypsum. These potential advantages are somewhat speculative because the anhydrite market is currently small relative to that of gypsum in the U.S. However, if a relatively cheap source of anhydrite is developed, the use of anhydrite could increase in a couple different applications that were previously mentioned.

At temperatures above $40^{\circ} \mathrm{C}\left(104^{\circ} \mathrm{F}\right)$, anhydrite is thermodynamically more stable than gypsum, yet typical forced oxidation FGD systems operating at $49^{\circ}$ to $60^{\circ} \mathrm{C}\left(120^{\circ}\right.$ to $140^{\circ} \mathrm{F}$ ) produce only gypsum. This results from much more rapid precipitation kinetics of gypsum relative to anhydrite.

A typical rate expression for solids precipitation is presented in Equation 1:

$$
\text { Precipitation Rate }=\mathrm{k} \cdot \mathrm{A} \cdot\left(\mathrm{RS}^{1 / \mathrm{n}}-1\right)^{\mathrm{p}}
$$

where $\mathrm{k}$ is a temperature dependent rate constant, $\mathrm{A}$ is the total solid surface area, RS is the relative saturation, and $\mathrm{n}$ and $\mathrm{p}$ are empirical constants. The relative saturation of gypsum is expressed as follows:

$$
\mathrm{RS}_{\mathrm{gyp}}=\left(\mathrm{a}_{\mathrm{Ca}} \cdot \mathrm{a}_{\mathrm{SO} 4} \cdot \mathrm{a}_{\mathrm{H} 2 \mathrm{O}}{ }^{2}\right) / \mathrm{K}_{\mathrm{sp}, \text { gyp }}
$$


where $\mathrm{a}_{\mathrm{Ca}^{\prime}} \mathrm{a}_{\mathrm{SO} 4}$, and $\mathrm{a}_{\mathrm{H} 2 \mathrm{O}}$ represent the activities of the calcium ion, the sulfate ion, and water, respectively and $K_{s p, g y p}$ is solubility product constant for gypsum. The relative saturation of anhydrite is identical except the water term, $\mathrm{a}_{\mathrm{H} 2 \mathrm{O}}{ }^{0}$, is omitted as it is always 1.

A graph of the solubility of gypsum and anhydrite as a function of temperature and ionic strength is shown in Figure 4-2. The solubilities shown were calculated using Radian's Aqueous Chemical and Physical Properties (ACAPP) computer model. Both solids exhibit inverse temperature relationships, but only the activity product of gypsum shows a dependence on the solution ionic strength. Figure 4-2 shows that the solubility of gypsum increases with ionic strength while the anhydrite solubility does not change significantly. This ionic strength relationship provides a means of increasing the degree of anhydrite supersaturation at a given temperature while remaining subsaturated with respect to gypsum. Empirical data show that precipitation from solutions supersaturated with respect to gypsum yields only gypsum, even though at temperatures above $40^{\circ} \mathrm{C}\left(104^{\circ} \mathrm{F}\right)$ the solutions are supersaturated in both solids. Apparently, to produce anhydrite from solution, the concentrations must be maintained just below the gypsum equilibrium solubility so gypsum will not form.

In the proposed process, calcium sulfite produced in the FGD process is converted to anhydrite in a secondary reaction tank by oxidation of sulfite to sulfate and subsequent precipitation of anhydrite. As discussed above, the kinetics of anhydrite precipitation are relatively slow at typical FGD operating conditions. To increase the precipitation rate of anhydrite, the process must be operated at an elevated temperature and at a high ionic strength. As shown in Figure 4-2, gypsum solubility increases with ionic strength while anhydrite solubility does not. Based on information in Figure 4-2, conditions can be chosen that provide a driving force for anhydrite precipitation while the solution remains subsaturated with respect to gypsum (i.e., gypsum will not be formed). Points A and B in Figure 4-2 represent such points at lower and higher ionic strengths, respectively. The driving force for anhydrite precipitation is represented by the distance between either Point A or B and the solid line. By increasing the solution ionic strength, the driving force for anhydrite precipitation can be increased without forming gypsum solids. Thus, a combination of elevated temperature and ionic strength must be used to provide the needed driving force to precipitate anhydrite economically.

Batch tests conducted prior to this PRDA project determined the precipitation rate of anhydrite from a high ionic strength solution at a typical FGD operating temperature. Based on these data, an anhydrite precipitation rate was calculated from the slope of a fitted exponential function. This rate was sufficiently high to warrant further investigation to determine how the rate might be further increased. The success of the anhydrite process depends on finding a set of operating conditions under which the anhydrite precipitation rate is sufficiently fast to yield an economically sized reaction tank and which minimizes gypsum production. 


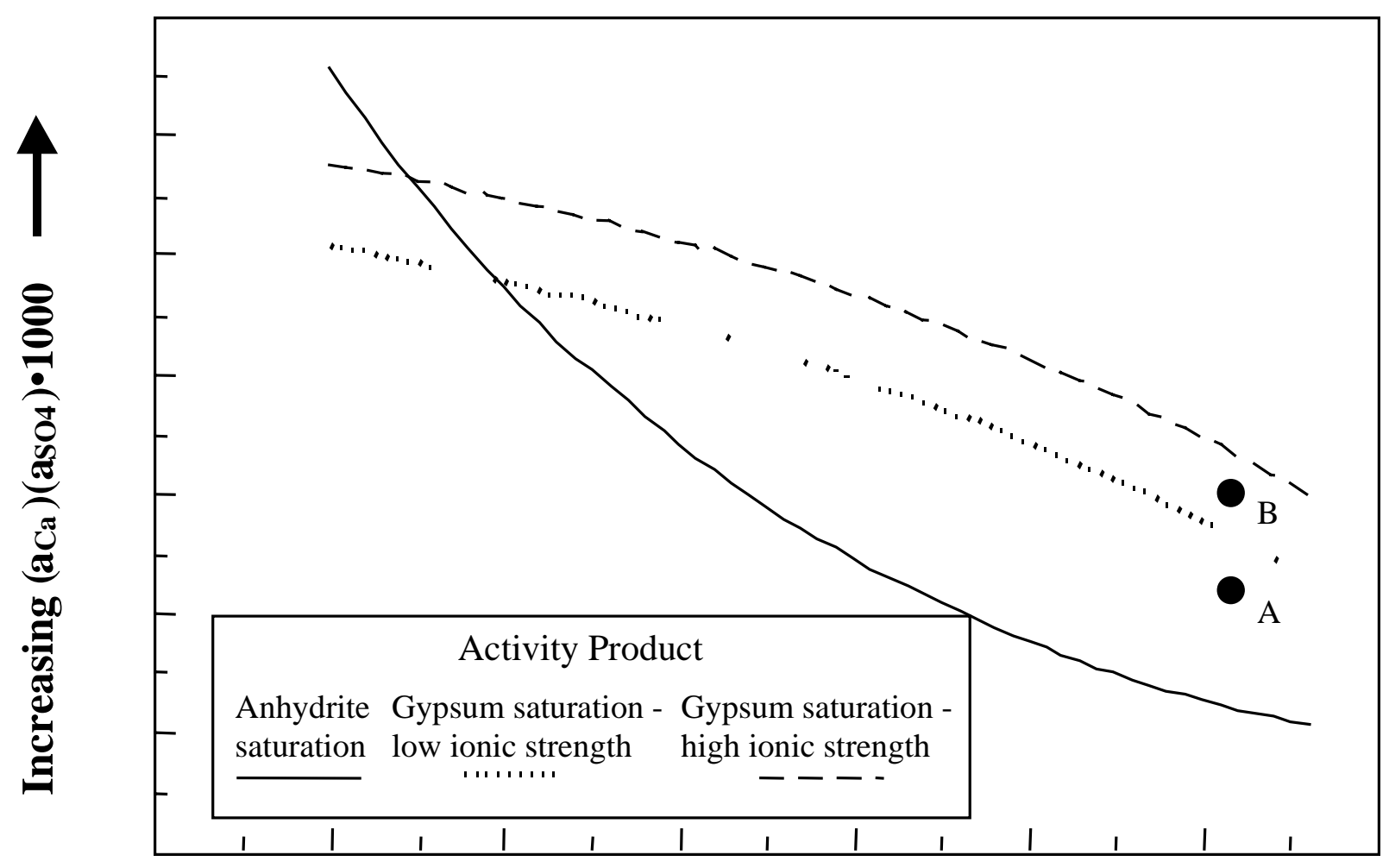

Increasing Temperature

Figure 4-2. Calcium Sulfate Solubility Data 



\section{5}

\section{LABORATORY TESTING}

The first step in the project was to perform batch and flow-through experiments in the laboratory to confirm the theoretical calculations and preliminary laboratory results that indicate condition for anhydrite formation. These laboratory experiments were designed to prove that anhydrite can be produced under conditions that can be reasonably achieved in a process external to an FGD system. Since gypsum is the kinetically favored sulfate species at typical FGD conditions, parameters needed to be identified so that production of reasonably pure anhydrite at reasonable rates could be demonstrated prior to further development of the anhydrite process at the pilot scale. This section documents the successful completion of the laboratory work.

Both batch and flow-through experiments were conducted to confirm expected trends generated from computer modeling and preliminary experimental results. The effects of important process variables - ionic strength, temperature, residence time, and solution composition-on the growth rate and purity of anhydrite were investigated. In both batch and flow-through tests, anhydrite precipitation rates were measured that are equivalent to gypsum precipitation rates at typical FGD conditions $\left(0.06 \mathrm{~g} / \mathrm{g}_{\text {seed }} \mathrm{hr}\right.$ at $\left.52^{\circ} \mathrm{C} / 125^{\circ} \mathrm{F}\right)$. This indicates that tanks of an economically attractive size may be used in the production of anhydrite at the commercial scale, so long as another process not simulated in the laboratory (such as calcium sulfite dissolution) does not become rate limiting.

\section{Batch Testing}

The batch experiments investigated the effects of temperature, ionic strength, and solution composition on the precipitation of anhydrite. The objectives of these experiments were to obtain estimates of the anhydrite precipitation rate under a diverse set of conditions and to determine the optimum solution composition and temperature ranges for producing anhydrite.

\section{Batch Approach}

A schematic of the batch reactor used in these experiments is shown in Figure 5-1. Table 5-1 summarizes the batch experiment variables. 


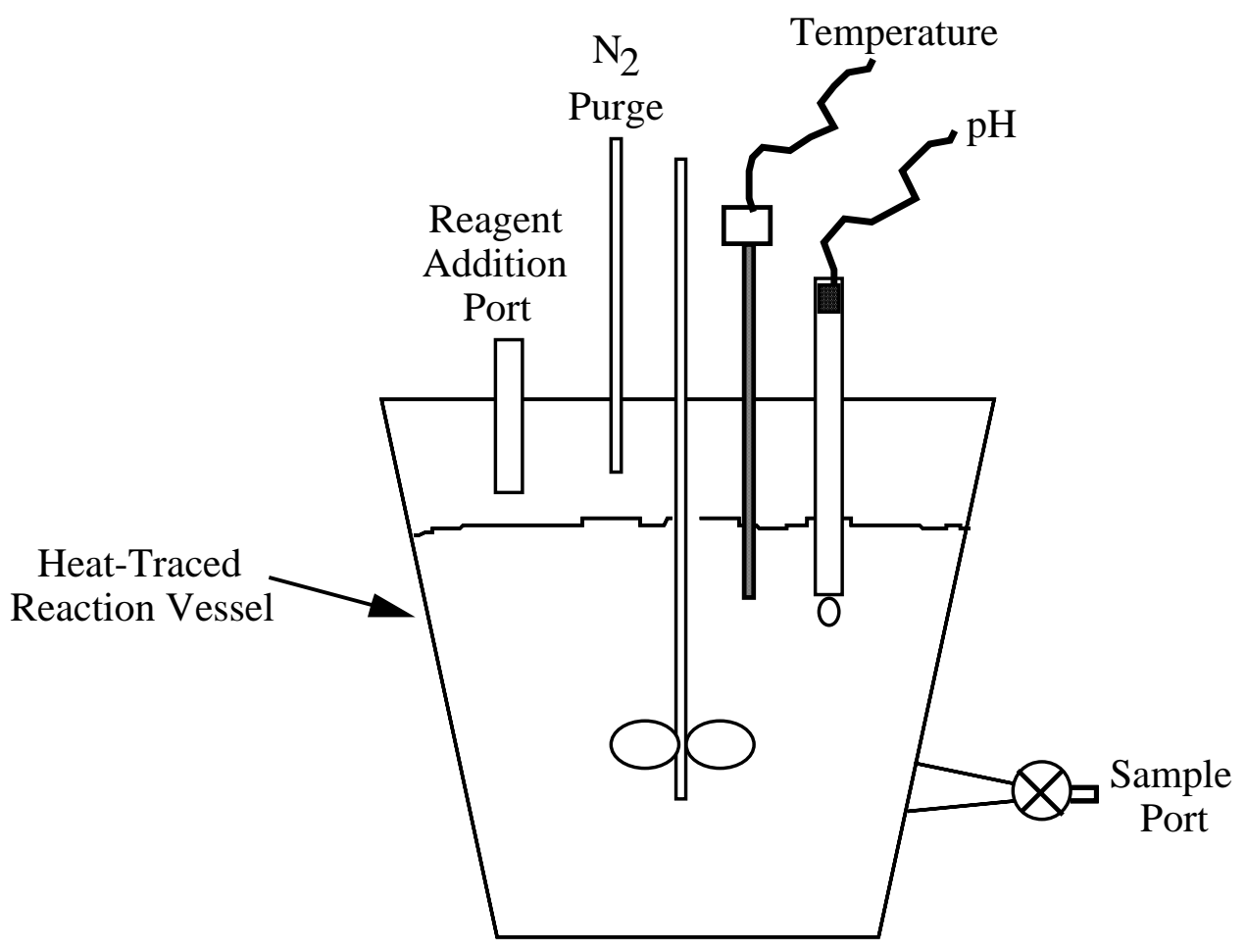

Figure 5-1. Lab-Scale Batch Reactor

Table 5-1. Anhydrite Formation Lab-Scale Batch Test Conditions

\begin{tabular}{cc} 
Variable & Range \\
\hline Seed Loading & $20 \mathrm{~g} / \mathrm{l}$ \\
Temperature & Median $+12^{\circ} \mathrm{C}$ to median $-15^{\circ} \mathrm{C}$ \\
Ionic Strength $[$ as $\mathrm{NaCl}]$ & Median $+1 \mathrm{M}$ to median $-1.5 \mathrm{M}$ \\
{$\left[\mathrm{Na}_{2} \mathrm{SO}_{4}\right]$} & 0 to $100 \%$ of total $\mathrm{Na}$ \\
{$\left[\mathrm{CaCl}_{2}\right]$} & 0 to $75 \%$ of total $\mathrm{Cl}$ \\
\hline
\end{tabular}

Prior to beginning each batch run, the working solution (with desired composition) was first saturated in gypsum at the appropriate temperature. The solution should have been supersaturated with respect to anhydrite under these conditions. The reactor was insulated and equipped with a thermocouple and heater to maintain the temperature desired. Anhydrite seed crystals were added to initiate precipitation, and the precipitation rate was monitored by analyzing samples for dissolved calcium and sulfate concentration over time as the solution approached equilibrium conditions. 
Solid samples at the conclusion of each run were analyzed for purity by either thermal gravimetric analysis (TGA) or infrared (IR) analysis to confirm the absence of gypsum.

\section{Batch Results}

The results of successfully completed batch experiments are summarized in Figures 5-2 through 5-4 and are discussed below. Although the amount of solids precipitated in any run was relatively small relative to the initial seed material, analysis by TGA and IR showed that no gypsum formed in any experiment.

The concentration versus time data in the figures were fit with correlations of the form:

$$
\mathrm{C}=\mathrm{X}-\mathrm{Y} \cdot \ln (\mathrm{t}+\mathrm{Z})
$$

where $\mathrm{C}$ is the concentration and $\mathrm{X}, \mathrm{Y}$, and $\mathrm{Z}$ are constants for a given batch experiment. To compare the precipitation rates for the batch runs in a consistent manner, these correlations were differentiated with respect to time to yield an expression for the precipitation rate:

$$
-\mathrm{dc} / \mathrm{dt}=\mathrm{Y} /(\mathrm{t}+\mathrm{Z})
$$

These expressions were evaluated at an elapsed time of 10 minutes for comparison. The resulting rate was divided by the mass of anhydrite seed material to determine the specific precipitation rate. The precipitation rate measured varied from 0.0005 to 0.051 $\mathrm{g} / \mathrm{g}_{\text {sed }}-\mathrm{hr}$. The following paragraphs discuss the observed effects of key variables.

\section{Effect of Temperature}

Three batch tests were conducted at equal ionic strength values, but with the solution temperatures varied over a $27^{\circ} \mathrm{C}\left(49^{\circ} \mathrm{F}\right)$ range. The results of these tests show the expected increase in reaction rate as the temperature increases over this range. If the rate constant were to exhibit an Arrhenius-type relationship with temperature $(\mathrm{k}=$ $\mathrm{Ae}^{-\mathrm{E}^{*} / \mathrm{RT}}$ ), a plot of the log of the precipitation rate versus $1 / \mathrm{T}$ (in ${ }^{\circ} \mathrm{K}$ ) should yield a straight line. Figure 5-2 shows this relationship. The precipitation rate increases by slightly more than a factor of two for each $10^{\circ} \mathrm{C}$ temperature rise over the range tested.

The most important finding from these batch experiments is that anhydrite can be precipitated at rates equivalent to gypsum precipitation at typical FGD conditions $(0.06$ $\left.\mathrm{g} / \mathrm{g}_{\text {sed }}-\mathrm{hr}\right)$. A $0.05 \mathrm{~g} / \mathrm{g}_{\text {sed }}-\mathrm{hr}$ precipitation rate was measured at the highest solution temperature tested. 


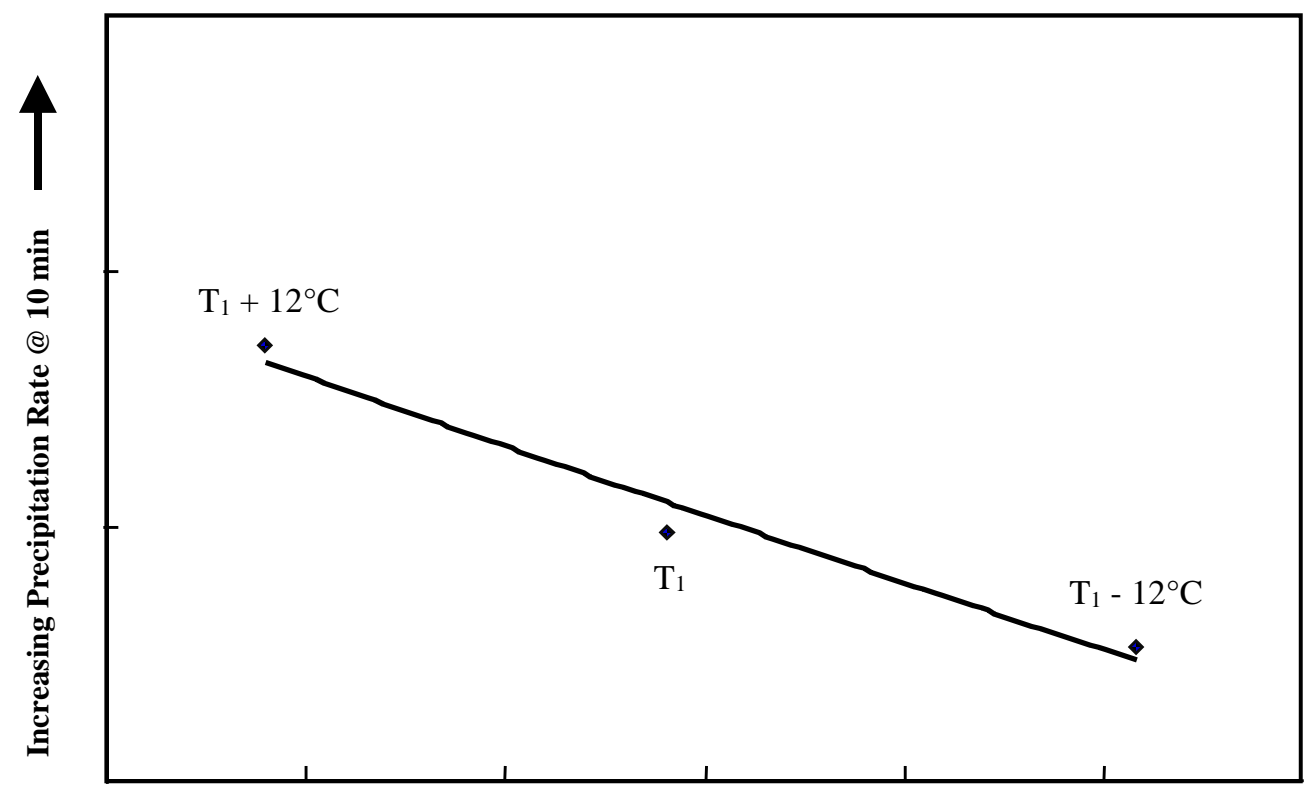

$1 / \mathrm{T}, \mathbf{1} /{ }^{\circ} \mathrm{K}$

Figure 5-2. Effect of Temperature on Batch Precipitation Rate

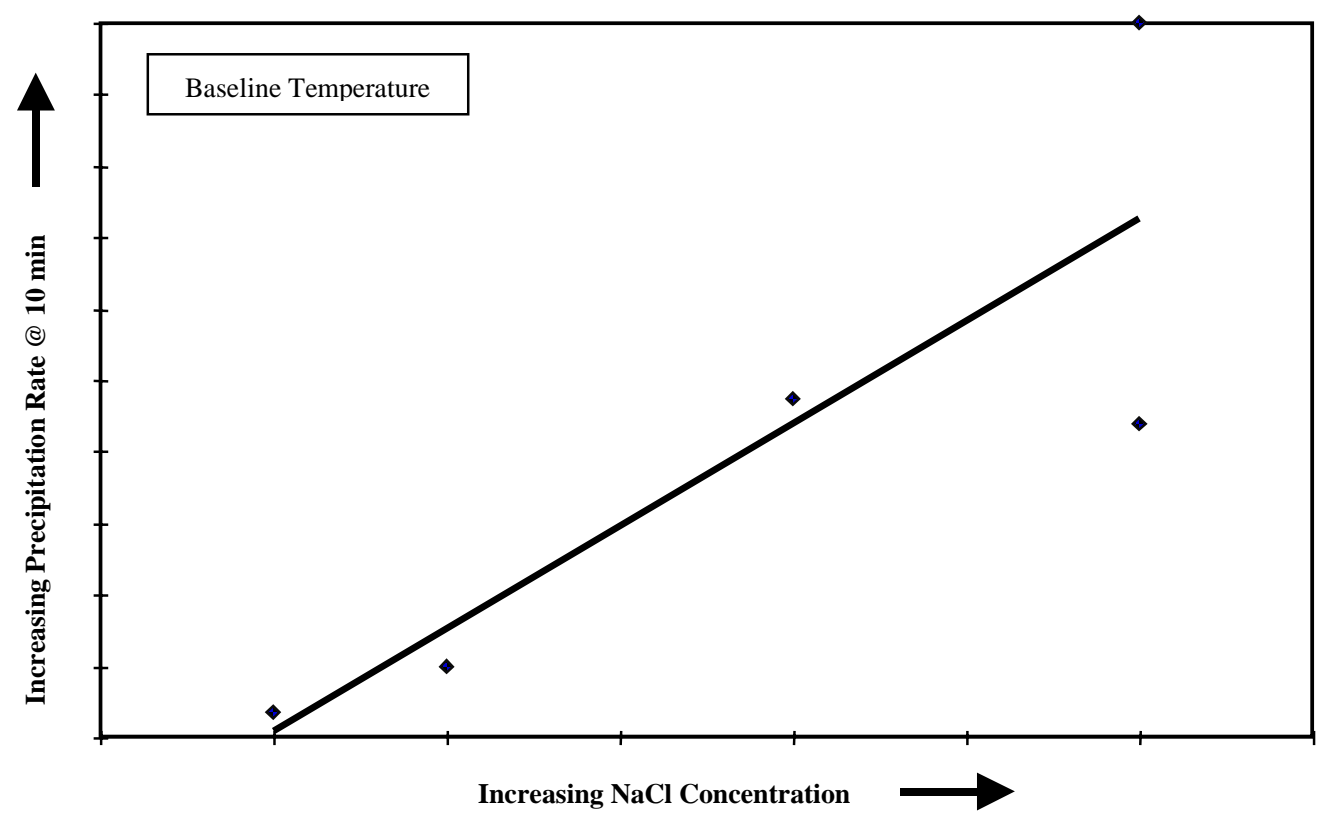

Figure 5-3. Effect Solution Strength on Anhydrite Precipitation Rate ( $\mathrm{NaCl}$ Solutions) 


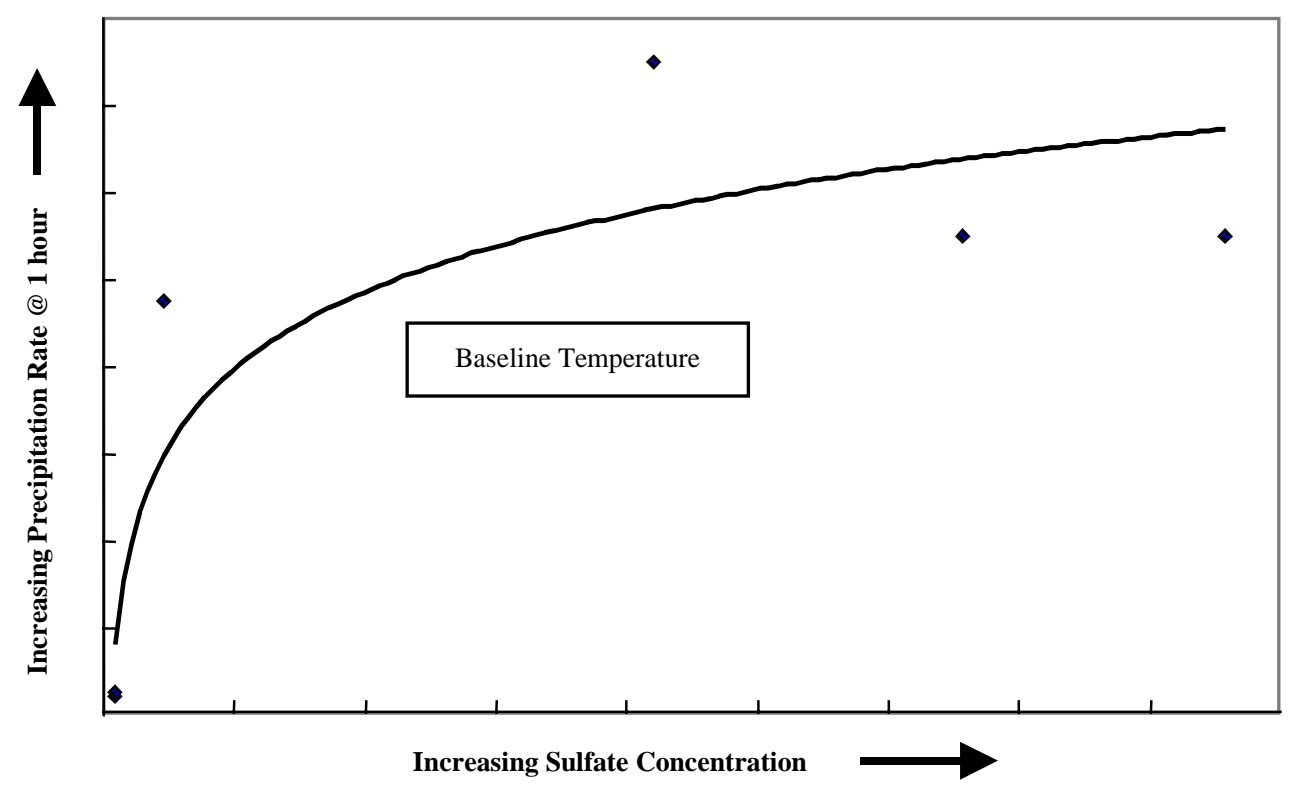

Figure 5-4. Effect of Sulfate Concentration on Anhydrite Precipitation Rate

\section{Effect of Solution Strength and Composition}

According to theoretical calculations (see Section 4), the anhydrite precipitation rate should be greater at higher ionic strength (higher concentration of dissolved solids). This effect was observed in the batch tests as shown in Figure 5-3. There was more than a 20 -fold increase in the precipitation rate as the $\mathrm{NaCl}$ concentration increased by a factor of 6.0. Clearly, for anhydrite production to be successful, higher ionic strength solutions will have to be used.

It was also believed that anhydrite would precipitate more rapidly from solutions higher in sulfate concentration relative to calcium concentration. This is because the calcium ion should be more quickly oriented in the forming crystal than the sulfate ion due to shape and spatial considerations. In the $\mathrm{NaCl}$ tests the calcium and sulfate concentrations are equimolar. This is because they were formed by saturating a pure $\mathrm{NaCl}$ solution with gypsum. Additional tests were run to determine solutions composition effects. The effect of sulfate concentration on anhydrite precipitation rate is shown in Figure 5-4. It appears that solutions dominated by $\mathrm{CaCl}_{2}$ (low in sulfate concentration) will not precipitate anhydrite nearly as rapidly as higher sulfate solutions. Figure 5-4 shows that sulfate and calcium must be present at least in equimolar quantities to achieve adequate precipitation rates. Although there is scatter in the data, solutions with much higher sulfate-to-calcium ratios do not appear to offer an additional significant increase in precipitation rate. The chloride control process 
included in this project should reduce the dissolved chloride concentration in the FGD process liquid so that acceptable ratios of calcium to sulfate for anhydrite formation are achieved.

\section{Flow-Through Reactor Testing}

Several liquid flow-through, batch solids runs were conducted to confirm rates measured in the batch experiments. The batch rates are determined by differentiating concentration data obtained from a solution which is continually changing in composition. The flow-through tests approach a steady-state solution composition more similar to a continuous full-scale process, and, for this reason, the flow-through results are more representative of the final commercial process. However, the batch solids allows these tests to reach a solution steady state much more quickly than typical mixed suspension, mixed product reactor (MSMPR) experiments.

\section{Flow-Through Test Approach}

Following the completion of the batch tests, several flow-through tests were conducted to make additional precipitation rate measurements at conditions approaching the steady-state conditions of a continuous full-scale process. These flow-through experiments were conducted using the lab-scale apparatus shown in Figure 5-5. The conditions of the successfully completed flow-through runs are summarized in Table $5-2$.

Each experiment was conducted allowing liquid to flow through the reactor and approach steady-state composition. The solids were retained in the reactor throughout the experiment. The reaction solutions were prepared by metering separate streamscontaining calcium and sulfate ions, respectively-into the flow-through vessel. The inlet streams contained the appropriate concentrations of sodium and chloride ions to achieve the desired ionic strength levels and sufficient calcium and sulfate to achieve the desired residence times and saturation level once they were combined at predetermined flow rates. The two streams were introduced into separate parts of the reactor to minimize possible localized regions of higher concentrations. The inlet concentrations and flow rates remained constant throughout an experiment.

After mixing the inlet reagents in the reactor, the experiment was initiated by adding anhydrite seed crystals to the vessel, and then beginning solution flow at a constant setting. The reaction slurry was mixed using an overhead stirrer operated at a high enough speed to maintain solids in suspension. The reaction liquid was forced through a filter membrane at the bottom of the reactor as the inlet feed liquid entered the reactor. Liquid samples were taken routinely during the runs and analyzed for calcium (and later for sulfate) to determine when the solution composition approached a 


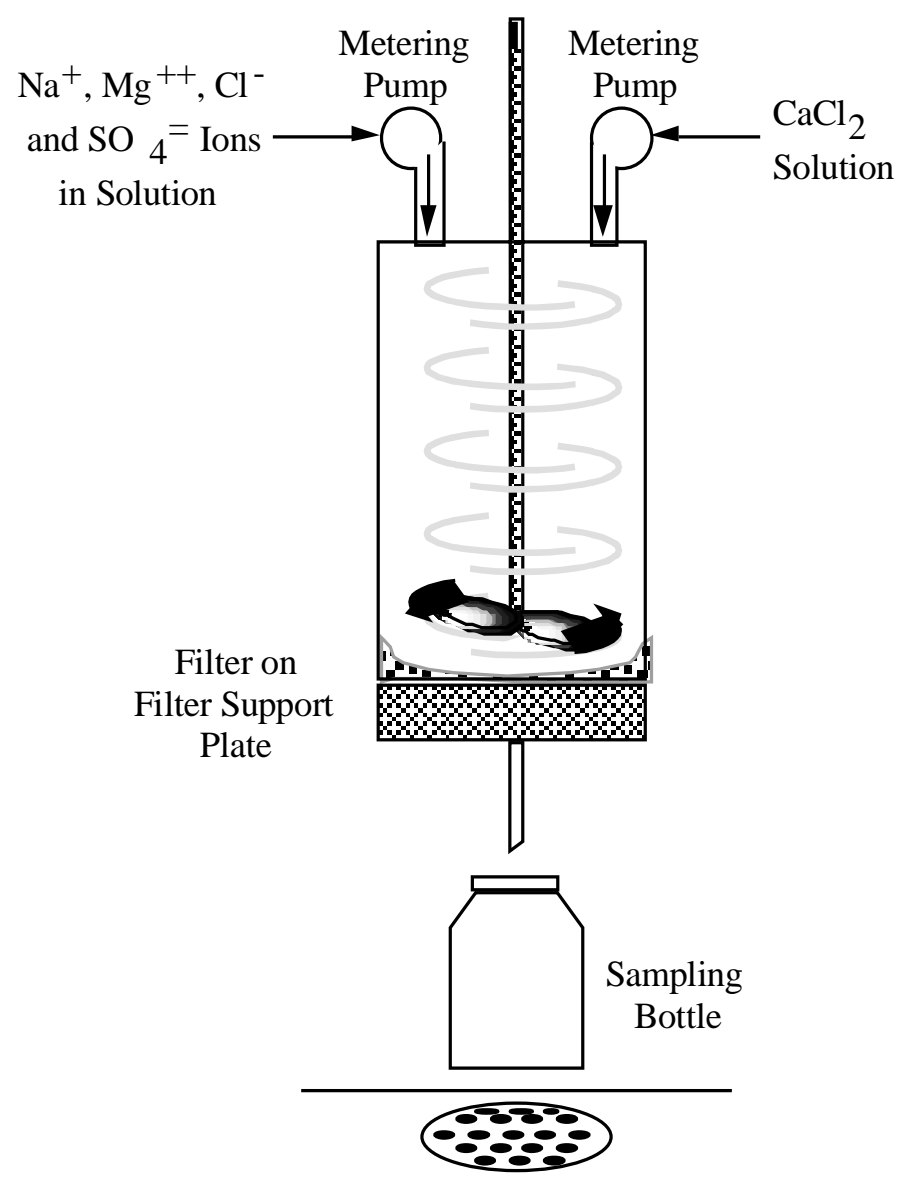

Figure 5-5. Flow-Through Crystallizer

Table 5-2. Anhydrite Formation Flow-Through Test Conditions

\begin{tabular}{cc} 
Variable & Range \\
\hline Seed Loading & $25-100 \mathrm{~g} / \mathrm{L}$ \\
$\mathrm{pH}$ & Median +5.2 units to Median -0.4 units \\
Temperature & Median $+8^{\circ} \mathrm{C}$ to Median $-7^{\circ} \mathrm{C}$ \\
Flow Rate & $10-40 \mathrm{~mL} / \mathrm{min}$ \\
Feed Ca Concentration & $16-57 \mathrm{mmole} / \mathrm{L}$ \\
Feed $\mathrm{SO}_{4}$ Concentration & $800 \mathrm{mmole} / \mathrm{L}$ \\
\hline
\end{tabular}


steady-state value. The solids were collected at the conclusion of each run and analyzed by TGA and/or IR to determine if gypsum or anhydrite had been precipitated.

\section{Flow-Through Test Results}

The initial runs were conducted such that the composition of the inlet stream (calculated by assuming complete mixing of the two streams) was slightly subsaturated with respect to gypsum. Different anhydrite seed loadings and feed solution flow rates were tested over a $10^{\circ} \mathrm{C}\left(18^{\circ} \mathrm{F}\right)$ reactor temperature range to develop an understanding of the steady-state precipitation rates. The $\mathrm{pH}$ was also decreased substantially for one run and iron added to the reactor for another run to determine if either had a positive effect on the precipitation rate.

The anhydrite precipitation rates measured in the first several tests were much lower than the initial rates measured in the batch experiments (based on comparison of batch rates at similar solution composition and temperature). Changes were made in some of the variables that affect the precipitation rate (per gram of seed) in the flow-through tests including the feed rate to the reactor, calcium concentration in the feed solution, and amount of anhydrite in the initial charge to the reactor. Results from later tests show that anhydrite precipitation rates of 0.03 to $0.04 \mathrm{~g} / \mathrm{g}_{\text {seed }}-\mathrm{hr}$ were achieved at the highest temperature tested. Runs were not conducted at the lowest temperature with lower seed loadings because of time and budget limitations.

The effect of $\mathrm{pH}$ and iron (a known modifier of crystal surface reactions) addition were examined in an attempt to increase the anhydrite formation rate. The effect of $\mathrm{pH}$ was negligible, while iron addition actually decreased the anhydrite precipitation rate compared to runs under otherwise similar conditions. Apparently iron affects the anhydrite surface reaction but in a deleterious manner.

The final two runs were conducted at substantially higher inlet calcium concentrations (57 mmole/L compared to $16 \mathrm{mmole} / \mathrm{L}$ ) to see if the precipitation rate could be further increased. A rate of $0.11 \mathrm{~g} / \mathrm{g}_{\text {seed }}-\mathrm{hr}$ was achieved at the highest temperature tested. Analysis by IR indicated that no gypsum was formed. At the lowest temperature tested $\left(10^{\circ} \mathrm{C}\right.$ or $18^{\circ} \mathrm{F}$ lower than the highest temperature), a rate of $0.8 \mathrm{~g} / \mathrm{g}_{\text {seed }}$-hr was measured, but IR analysis indicated the presence of substantial amounts of gypsum at the end of the run.

\section{Preliminary Energy Balances}

Since the temperature is of such importance in formation of anhydrite, some preliminary energy balances were performed to determine if heat input would be required. Assumptions made for these calculations include:

- Adiabatic conditions; 
- Feed stream contained 30 weight $\%$ solids, $90 \%$ of which were calcium sulfite;

- $\mathrm{O} / \mathrm{SO}_{2}$ ratio of 2 (sets the air rate);

- Reactor height of $7.3 \mathrm{~m}$ (24 feet);

- No external heat added; and

- No heat exchangers for heat recovery.

The results of the calculations indicate an operating solution temperature near the upper end of the range tested in the flow-through reactor. This demonstrates that the desired operating temperature can be approached without external heating. Should additional heating or heat recovery be required to optimize anhydrite formation, the requirements will be relatively small.

\section{Results Summary}

The laboratory results suggest that reasonable precipitation rates may be achieved from FGD solutions provided the sulfite dissolution or oxidation reactions are not rate limiting. The important findings from the laboratory were:

- Anhydrite precipitation rates equivalent to typical gypsum precipitation rates at FGD forced oxidation conditions were achieved in both the batch and flow-through experiments. Consequently, the reaction tank for anhydrite will be of a size similar to current reaction vessels.

- To achieve the higher precipitation rates, reaction temperatures should be at the upper end of the range tested. A preliminary energy balance calculation shows that a temperature near that value can be achieved in the anhydrite reactor without external heat added and without heat exchangers.

- Higher ionic strength solutions (higher concentrations of total dissolved solids) increase the anhydrite precipitation rate.

- High concentrations of calcium relative to sulfate dramatically slow the anhydrite precipitation rate. (This situation might be encountered with a coal of relatively high chloride content such that the flue gas contained high concentrations of $\mathrm{HCl}$. However, the chloride removal process included in this PRDA or addition of sodium or magnesium would raise the sulfate-to-calcium ratio into the correct range.)

Integration of the anhydrite precipitation with calcium sulfite dissolution and oxidation and determination of the steady-state crystal size distribution at the ECTC were recommended based on these findings. The pilot scale was recommended since the continuous operation of the FGD system and anhydrite production process were more easily accomplished. The size of the equipment made the crystal size determination more meaningful in proof-of-concept testing since the agitator tip speeds and pump 
Laboratory Testing

impeller velocity (which affect crystal breakage and secondary nucleation) are much more similar to full-scale equipment than the laboratory equipment. 


\section{6}

\section{PILOT TESTING}

Following the successful completion of the laboratory testing and after receiving approval from DOE, testing at the ECTC began in January 1997 on the 4-MW pilot wet scrubbing facility. The pilot facility was configured to allow testing of both the $\mathrm{HCl}$ removal and anhydrite production portions of the CLS/anhydrite process. However, only a few tests of the $\mathrm{HCl}$ removal process were conducted; with DOE's concurrence most of the testing focused on anhydrite production. There were several reasons for this focus:

- Of the three sub-processes which makeup the CLS/anhydrite process, the anhydrite process was the least developed at the beginning of this project;

- Laboratory results were encouraging that anhydrite could be produced; and

- The U.S. electric utility industry has an interest in cost-effective processes that can convert FGD sludge to saleable byproducts.

Consequently, most of the results presented in this section pertain to anhydrite production. The results of a few $\mathrm{HCl}$ removal tests are included at the end of the section. No pilot-scale clear liquor scrubbing tests were conducted as part of this project.

\section{Pilot Test Approach}

The 4-MW pilot wet scrubber was configured as an inhibited oxidation system with an external oxidation tank set up as the anhydrite reactor. Figure 6-1 shows the pilot unit schematic for this test block.

Table 6-1 summarizes the variable ranges planned for the pilot tests, based on successful results from the laboratory testing. However, the planned conditions for reactor solid-phase residence time could not be achieved.

A tank with the required dimensions was not available at the ECTC. The vessel chosen for use as the reactor (the pilot first-loop reaction tank, or FLRT) had too small a heightto-diameter ratio. When this tank was operated at a slurry level that produced the desired solids residence time, the height of slurry in the tank was inadequate to allow complete oxidation of sulfite at the desired $\mathrm{O}$ to $\mathrm{SO}_{2}$ ratios. The oxidation air rate was increased beyond this range in an attempt to allow 100\% oxidation, but the high air rates cooled the slurry below the required temperature for producing anhydrite. For 


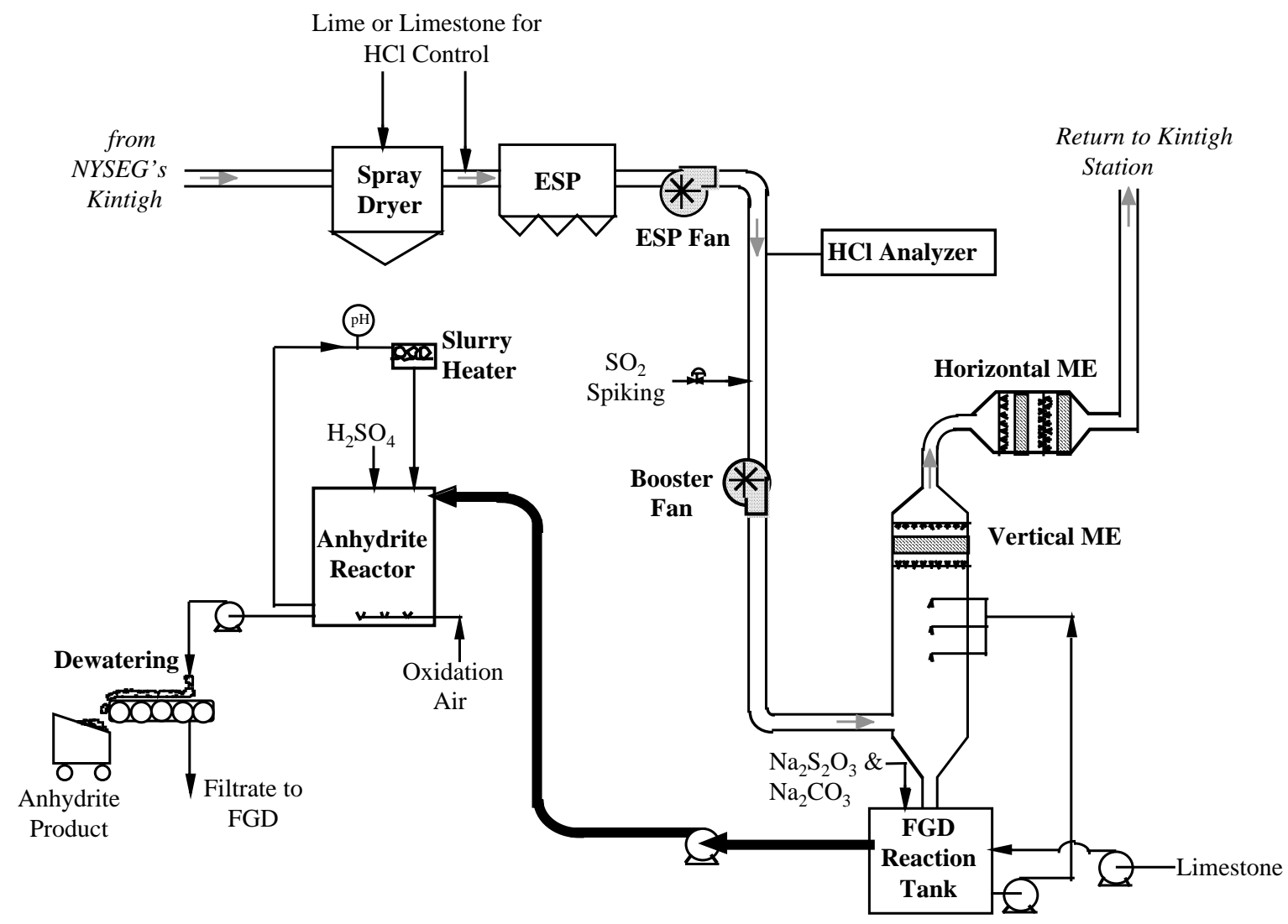

Figure 6-1. ECTC Flow Configuration for Anhydrite Test Block

Table 6-1. Variables and Planned Ranges of Interest in Anhydrite Development Pilot Work

\begin{tabular}{lc}
\hline \multicolumn{1}{c}{ Variable } & Range \\
\hline Solid Residence Time & $4-10 \mathrm{hrs}$ \\
Solid Concentration & $10-30 \mathrm{wt} \%$ \\
$\mathrm{O} \mathrm{SO}_{2}$ Ratio & $2-9$ \\
Reactor Temperature, (departure from median) & $\pm 5^{\circ} \mathrm{C}$ \\
$\mathrm{Na}$ Concentration, (departure from median) & $\pm 1 \mathrm{M}$ \\
Reactor pH (departure from median) & $\pm 0.7 \mathrm{units}$ \\
Organic Acid Concentration & $0-3,000 \mathrm{ppm}$ \\
\hline
\end{tabular}


the testing to proceed, the slurry level in the tank had to be raised, producing solids residence times in the range of 60 to 90 hours.

Because of these limitations, a number of the variables identified in Table 6-1 could not be tested in Phase I. In spite of these limitations, however, a good understanding of several important variable interactions was developed during the Phase I proof-ofconcept testing.

A number of techniques were employed to determine the phase of calcium sulfate produced in the pilot unit including:

- Percent bound water (measure solid weight loss at about $180^{\circ} \mathrm{C}\left[356^{\circ} \mathrm{F}\right]$ )-provides estimate of anhydrite $\mathrm{wt} \%$ assuming solids are mixture of only anhydrite and gypsum;

- X-ray diffraction (XRD) -indicates the presence of gypsum and/or anhydrite; and

- Visual microscope and scanning electron microscope (SEM) - indicate changes in particle size and shape.

The percentage of bound water and the visual microscope were available on site and were the primary means of characterizing the solids to provide operating feedback. In using the bound water as an indication, it was assumed that the solids were either anhydrite or gypsum. For $100 \%$ gypsum solids, the bound water should be about $21 \%$ by weight. Anhydrite should have no bound water. This assumption was necessary to estimate anhydrite concentrations since another potential product, calcium sulfate hemihydrate, has only $5 \%$ bound water and cannot be distinguished from a gypsum/anhydrite mixture. Visual observations of the centrifuge product were also valuable once experience with anhydrite production had been gained. The XRD and SEM were used in Radian's Austin laboratories to confirm on-site results.

\section{Pilot Results}

The initial operating conditions specified did not produce anhydrite at the ECTC pilot unit. Many of the problems were associated with converting an existing reaction tank to serve as the anhydrite reactor. To achieve the shorter residence times desired required the operating slurry level to be relatively low ( 6 feet) which increased the air rate required to achieve complete sulfite oxidation ( $>10$ moles unbonded oxygen per mole of $\mathrm{SO}_{2}$ ). Since one of the major heat losses associated with this process is the heat of vaporization of water vapor leaving with the spent oxidation air, the higher air rate prevented the target temperature from being reached. There were other heat losses as well, including inadequate insulation around the tank and lines to the $\mathrm{pH}$ measurement and sampling locations. Much of January was spent understanding and resolving the temperature limitations of the pilot anhydrite reactor. 
Figure 6-2 shows how the percentage anhydrite changed as a function of time during the proof-of-concept testing. Period 1 was the first attempt to make anhydrite. The desired temperature was not achieved until later in January. With the high ionic strength, high temperature, and long residence time, the reactor began to produce anhydrite with a maximum of about $50 \%$ achieved on January 27 . The percentage anhydrite decreased until January 30 at which time a plugged sparger apparently decreased the oxidation rate, reduced the temperature and stopped the anhydrite precipitation. The sparger could only be partially cleared by purging with air, so the tank was drained and the sparger cleaned. The anhydrite reactor achieved the desired operating temperature on February 3 following this cleaning.

Figure 6-3 shows the SEM and XRD results for the gypsum formed at the end of Period 1 (February 3). A comparison of the XRD scan of the sample (top) with the gypsum standard below shows the sample to be all gypsum. Peaks for anhydrite were not observed. The SEM shows the shape of the crystals to be typical of gypsum. Some of the crystals are quite large due to the 80- to 90-hour solid-phase residence time in the anhydrite reactor.

The operating conditions during Period 2 were the same as during Period 1 but with more consistent temperature control because the tank was better insulated. Figure 6-2 shows that significant amounts of anhydrite were produced in Period 2, and XRD analyses showed the solids to be a mixture of anhydrite and gypsum during this period. After cleaning the plugged sparger, the reactor produced solids that were over $90 \%$ anhydrite for 3 days (on the basis shown in Figure 6-2).

Figure 6-4 shows the XRD/SEM results from February 8 at the beginning of Period 2. The XRD sample shows peaks for gypsum and anhydrite. The SEM shows that the solids had changed to thinner rods with more rounded ends. The dewatered solids exiting the centrifuge became relatively hard within 24 hours. There was no significant temperature rise upon mixing the solids with water. These setting properties are consistent with anhydrite that is somewhat reactive.

The decrease in anhydrite content shown in Figure 6-2 on February 7 at the end of Period 1 occurred simultaneously with minor changes in oxidation air rate and reactor $\mathrm{pH}$. However, after returning to the previous conditions, the anhydrite content of the solids did not return to 90 percent. In fact, the anhydrite concentration decreased to only $20 \%$ by the end of Period 2 .

Following the drop in anhydrite content at the end of Period 2, it was postulated that the anhydrite nucleation rate was not sufficient to maintain anhydrite production without the use of a surface area control mechanism. Initially, the process seemed to form small crystals which would subsequently grow until the surface area was insufficient to maintain the gypsum relative saturation below 1 . Once the gypsum 


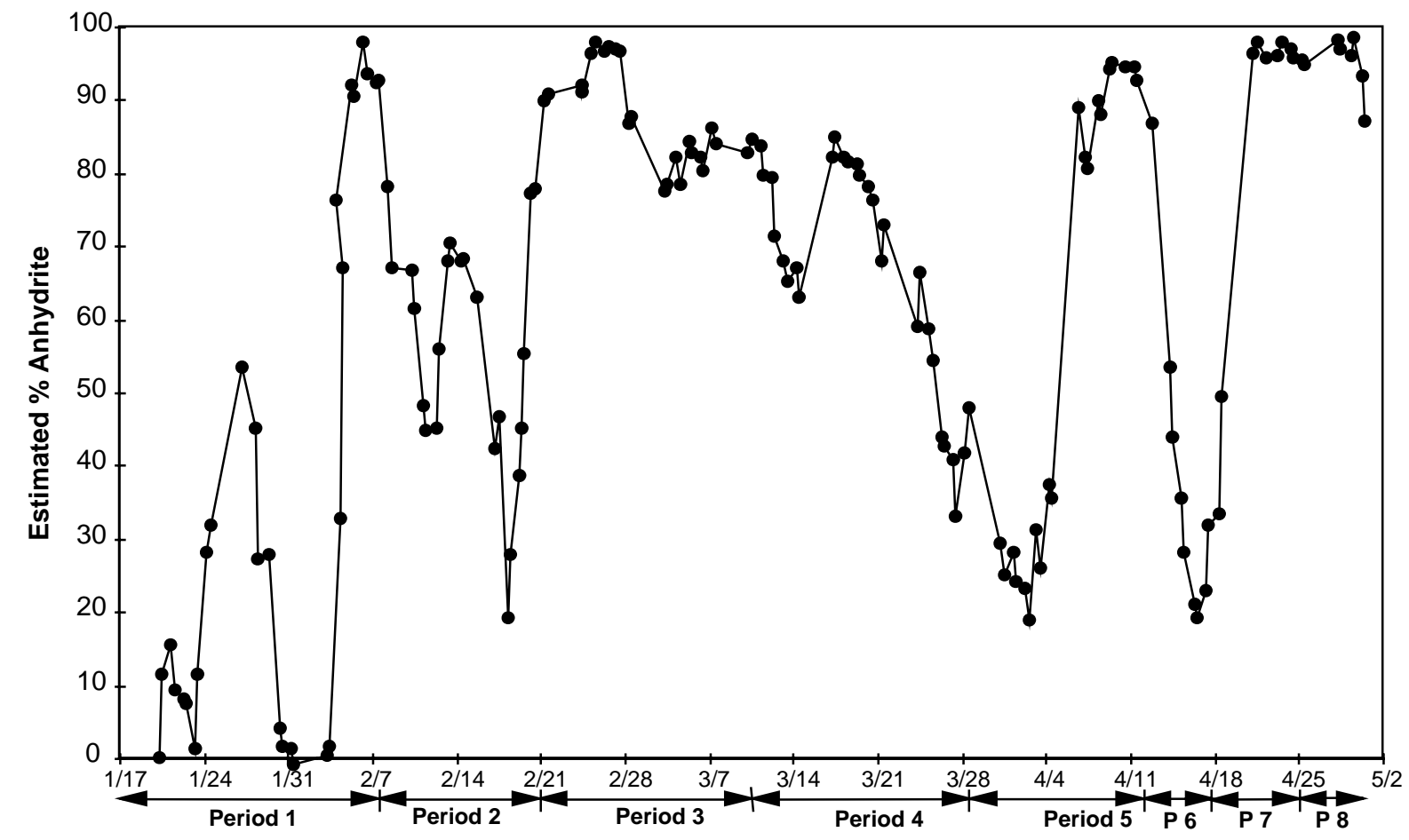

Figure 6-2. Anhydrite Content as a Function of Time (solids considered either gypsum or anhydrite based on bound water \%)
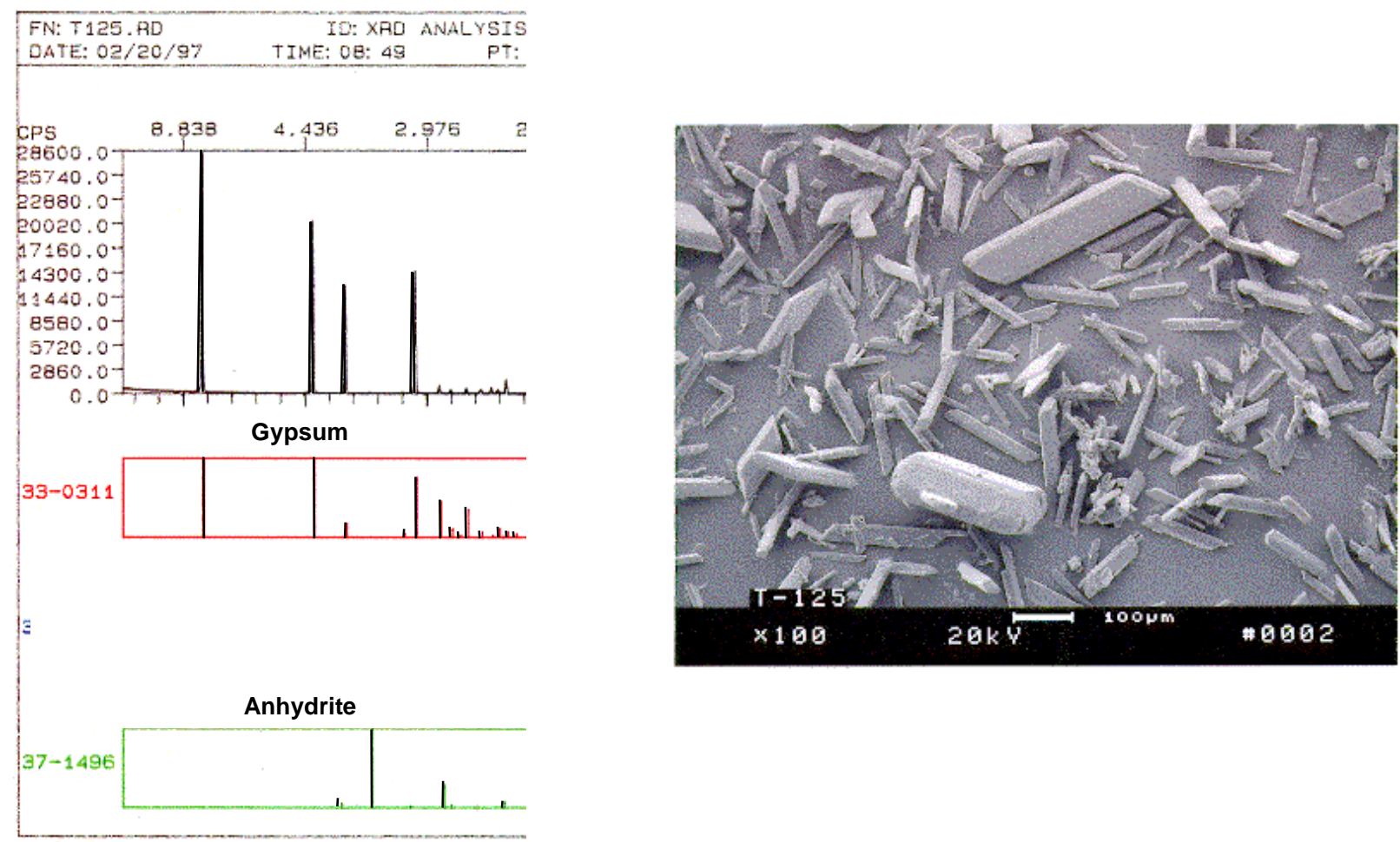

Figure 6-3. Period 1 (February 3) XRD/SEM Results (Gypsum) 

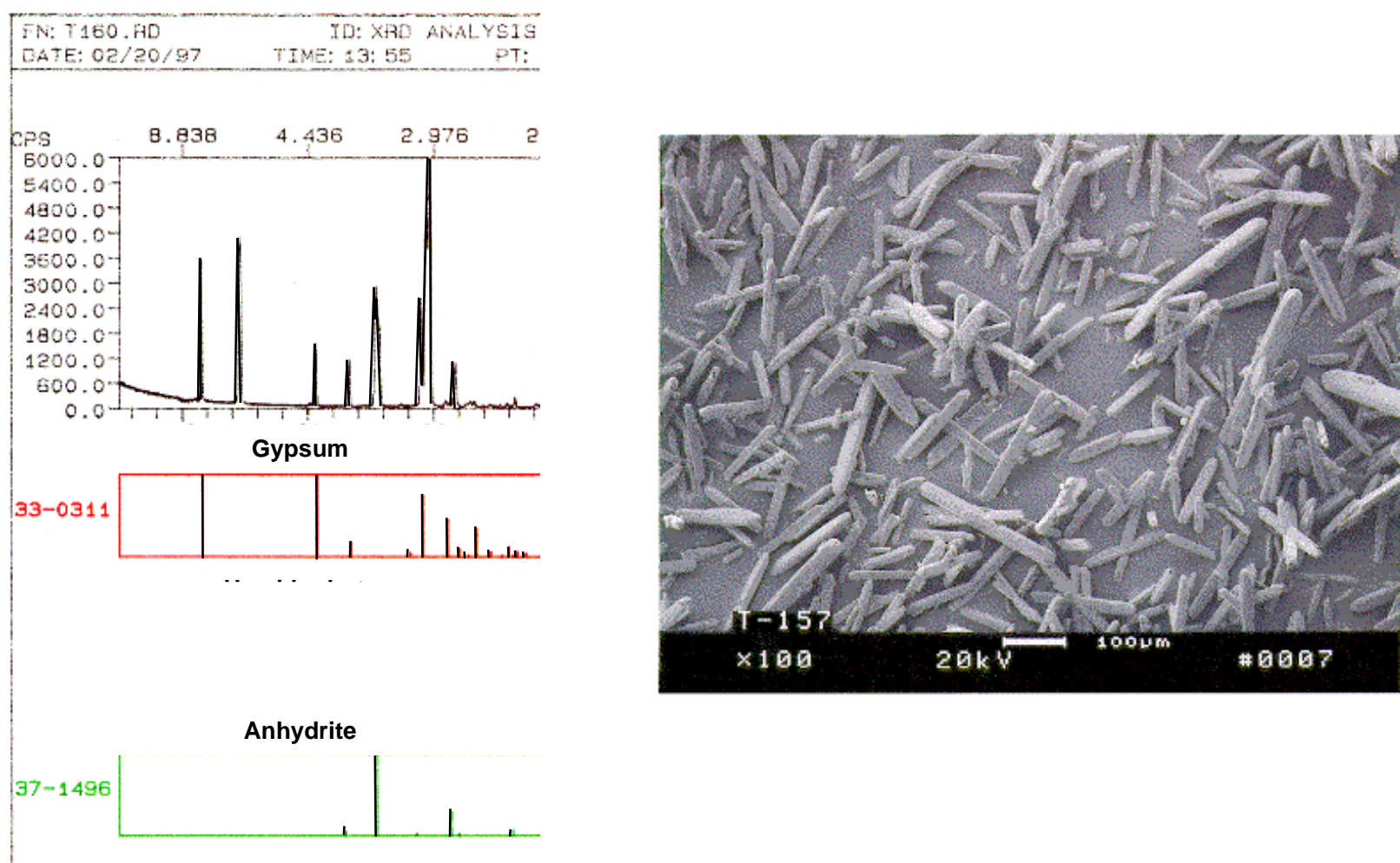

Figure 6-4. Period 2 (2/10/97) XRD/SEM Results (Gypsum and Anhydrite)

relative saturation exceeds 1 by any significant amount, gypsum will begin to form rapidly because of its faster precipitation kinetics. It was, therefore, decided to control the anhydrite surface area in the reactor. Surface area control by mechanism A1 was begun on February 19, and surface area control by a second mechanism (A2) was implemented from February 20 until March 11. This is designated Period 3 in Figure 62.

Figure 6-2 shows that the anhydrite content increased rapidly following initiation of the second surface area control mechanism, A2. The XRD of a sample taken on February 21 showed no gypsum. Over the next week, the solids produced were mainly anhydrite with small amounts of gypsum. The centrifuge product hardened upon cooling and set up overnight similar to the previous operation when anhydrite was present.

Over the following weekend, the characteristics of the centrifuge product changed dramatically. On March 3, these solids were hardening rapidly upon cooling (30 minutes to an hour) and the solids were forming one large rock in the collection dumpsters used at the ECTC. When the dumpsters were emptied into the trucks for ultimate disposal (typically several days later), the solids were discharged in a single piece which did not break apart when colliding with the truck bottom as had been observed previously. The bound water measurement and the XRD analyses showed the solids to be 80 to $90 \%$ anhydrite with the remainder gypsum. These characteristics were observed until the end of the period. Figure 6-5 shows the XRD and SEM results from 
March 5 (toward the end of Period 3). The XRD shows a majority of the solids to be anhydrite with small amount of gypsum. The SEM shows a change in crystal size and shape with smaller crystals that appear to be "stacked platelets" under the visual microscope.
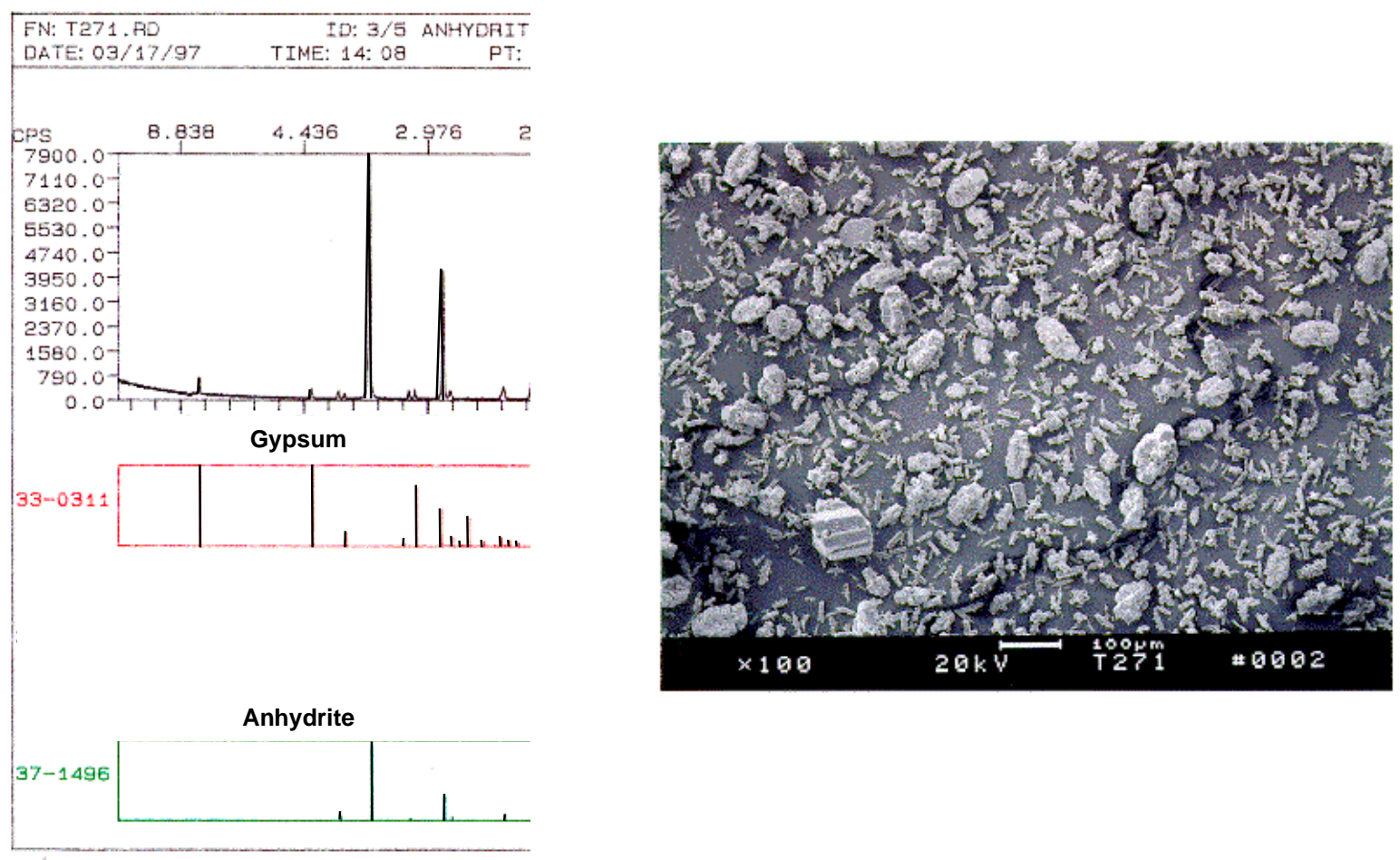

\section{Figure 6-5. Period 3 (3/5/97) XRD/SEM Results (Gypsum and Anhydrite)}

The operating period designated as Period 4 in Figure 6-2 began on March 11 when surface area control mechanism A2 was stopped. At this time, a new surface area control mechanism (B1) was implemented. Over the next two days, the anhydrite content decreased from $85 \%$ to $65 \%$ on March 14 . The centrifuge solids visually appeared to be drier and did not set as quickly or as hard as had the material throughout the latter stages of Period 2. Starting on March 14, surface area control mechanism B2 was implemented for the rest of Period 4.

The only exception to this was on March 15 when mechanism B3 was implemented for one day only. Samples taken on March 17 showed $82 \%$ to $85 \%$ anhydrite, and the centrifuge product had returned to its more reactive properties. Surface area control mechanism B2 was restored on March 16 and continued until March 28. The anhydrite content dropped to as low as $33 \%$ during this period. 
Figure 6-6 shows the XRD and SEM results of solids produced during Period 4. The XRD shows a large gypsum peak and an anhydrite peak. The SEM shows some very large gypsum crystals as well as some of the finer anhydrite crystals.
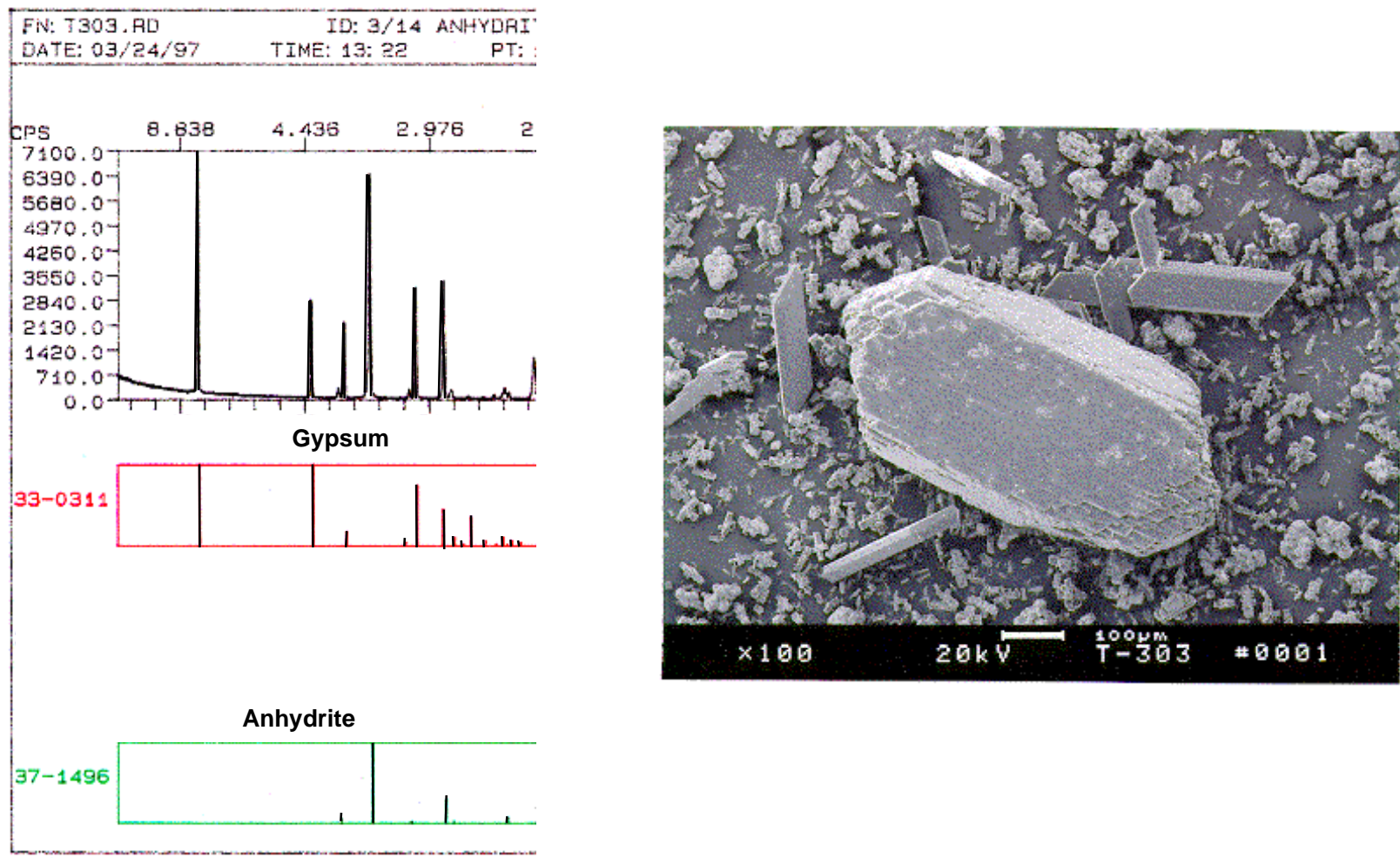

\section{Figure 6-6. Period 4 (3/14/97) XRD/SEM Results (Gypsum and Anhydrite)}

Implementation of surface area control mechanism $\mathrm{C} 1$ was begun on March 27. On March 28, surface area control mechanism C2 was implemented for one day only. Afterwards, mechanism C1 was used throughout the period until April 4. One exception was April 1, when no mechanism was used due to operator error. During this period, there were also periodic problems with $\mathrm{pH}$ control, and there was one day with a low temperature excursion.

Beginning April 4, surface area control mechanism C3 was implemented. The anhydrite content of the solids increased to $89 \%$ by April 6 remained between 80 and $95 \%$ through April 12. This is the period designated Period 5 in Figure 6-2.

On April 12, the solids concentration in the anhydrite reactor was decreased to determine the effect of solids residence time on anhydrite production. This was done by increasing the slurry discharge rate from the reactor and returning centrate from the 
centrifuge. Unfortunately, the centrate typically contains a small quantity of solids (less than $1 \%)$, and these solids converted to gypsum upon cooling in the centrate return tank before being recycled back to the process. Therefore, Period 6 (April 12 to 17) in Figure 6-1 showed a steady decline in anhydrite content because the operating procedure was actually seeding the anhydrite reactor with gypsum. This occurred in spite of implementing surface area control mechanism C4. The most desirable method of reducing the solids residence time is to decrease the tank size (diameter). Subsequent testing with the mini-pilot FLRT showed that anhydrite can be produced with a 30-hour solids residence time.

On April 17, the solids concentration in the anhydrite reactor was increased by decreasing the discharge rate and eliminating the centrate return. By April 21, the anhydrite content in the solids had increased to greater than $95 \%$ and remained above $95 \%$ until conditions were changed on April 24. This period is designated Period 7 in Figure 6-2.

The final few days before a NYSEG boiler outage, that marked the end of this testing, surface area control mechanism D1 was tested. This is shown as Period 8 in Figure 6-2. During this period, anhydrite continued to be produced.

\section{Extended Mini-Pilot Testing}

At the conclusion of the Phase I DOE/PRDA testing and the NYSEG outage in May, the facility was reconfigured to complete some EPRI sponsored anhydrite testing using the $0.4 \mathrm{MW}$ mini-pilot system. Using this equipment with a reduced staff allowed for extended testing at lower operating costs. Consequently, approximately six weeks of testing was completed on the mini-pilot from May 19 through July 2. In this configuration, the pilot scrubber was operated approximately once every three weeks under typical limestone conditions. The mini-pilot first loop reaction tank became the anhydrite reactor. The slurry from the pilot scrubber was combined with either soda ash or sodium sulfite to produce a sodium enhanced feed slurry in the mini-pilot main reaction tank. In the final test, magnesium hydroxide was mixed with pilot slurry to produce a magnesium enhanced feed slurry. In both cases, sulfuric acid was added to the feed tank and to the mini-pilot anhydrite reaction tank (m-ART) to control the $\mathrm{pH}$.

One of the main limitations of operating the process at these conditions is that the $\mathrm{m}$ ART is only 12 feet tall. Although a new oxidation air sparger was designed for these tests, the sulfite oxidation had to be supplemented with hydrogen peroxide to maintain both temperature and oxidation percentage throughout the test period. A second limitation of these tests was that the feed flow to the reaction tank was sometimes very low $(<0.2 \mathrm{gpm})$, pushing the lower limits of the existing equipment and causing some operational problems. However, with these limitations aside, the process was operated and controlled at the same conditions tested in Phase I. 
A total of three test conditions were evaluated in the extension testing:

- Baseline sodium enhanced with 90-hr solids residence time;

- Sodium enhanced with 30-hr solids residence time; and

- Magnesium enhanced with 90-hr solids residence time.

The objective of the first test was to demonstrate that the new configuration could produce anhydrite at the conditions similar to Phase I testing. In these tests, the sodium level was maintained at approximately the same levels as during the pilot tests, and the solids residence time was held at 90 hours. This test was successful in producing up to $97 \%$ anhydrite by the end of the test period.

The objective of the second test was to demonstrate that the anhydrite process could be operated at lower solids residence times than those used in Phase I. Most existing FGD systems run with a solids residence time ranging from 10 to 30 hours. Since tank size, and thus capital cost, is dependent on the required solids residence time of the process, it was important to demonstrate that this process could be operated at much lower residence times than tested in Phase I. Recall that an unsuccessful attempt at operating the process at a 60-hour residence time was confounded by fine gypsum particle recycling with the recycle water return. The second test completed during the extension produced up to $97 \%$ anhydrite when using the proper surface area control mechanism at only a 30-hour residence time.

The objective of final test completed during the extension was to evaluate the use of a magnesium enhanced slurry to feed the anhydrite process. During this test, a slurry with a magnesium molarity approximately equal to the sodium molarity in the baseline test was fed to the anhydrite reaction tank at a rate that produced a 90-hr residence time. Although high purity anhydrite was never produced during this test, a $69 \%$ anhydrite product was formed. Since none of the operating parameters were optimized during this test, it is likely that a higher purity product could be produced at other magnesium-enhanced conditions.

Overall, the extension testing was successful in demonstrating that the anhydrite process can be operated at solids residence times as low as 30 hours and with both sodium-enhanced and magnesium-enhanced slurries.

\section{Chloride Removal Process Testing}

As mentioned earlier in this report, maintaining a low chloride concentration in a FGD system has several potential benefits: minimal corrosion allowing the use of cheaper materials of construction; increased reagent utilization in limestone systems allowing lower reagent costs; and, reduced gypsum scaling potential in clear liquor processes allowing lower maintenance costs. In a closed-loop FGD system, without liquid 
blowdown, the hydrogen chloride $(\mathrm{HCl})$ concentration in the flue gas is important because it is directly related to the chloride concentrations of both the scrubbing liquid and the byproduct solids. One option for reducing flue gas $\mathrm{HCl}$ levels is the injection of alkaline slurry into the gas stream upstream of the wet scrubber and particulate control device. Four tests completed early in the Anhydrite test block investigated the effect of lime injection on $\mathrm{HCl}$ removal efficiency.

To conduct these tests, dilute lime slurry was fed to the atomizer of a pilot-scale spray dryer that was in the gas path upstream of the pilot ESP and wet scrubber. As the water in this slurry evaporated, it cooled and humidified the flue gas. Simultaneously, the slaked lime in the slurry reacted with flue gas $\mathrm{HCl}$ to form calcium chloride solids. These solids were subsequently removed in the ESP, and the chloride removed was prevented from entering the FGD system.

In the CLS/anhydrite process, this chloride removal step would likely be implemented by installing an array of two-fluid nozzles in the ductwork upstream of the ESP. These nozzles would feed the lime slurry, and the flue gas cooling, humidification, and $\mathrm{HCl}$ removal would occur within this duct. An existing spray dryer was used to accomplish these pilot-scale tests just to facilitate testing. The intent of these tests was to prove the concept of removing $\mathrm{HCl}$ from the flue gas by reaction with a slaked lime slurry. The concept of in-duct spray drying has been demonstrated by others, although for $\mathrm{SO}_{2}$ rather than $\mathrm{HCl}$ control.

For the first three tests, a $10 \mathrm{wt} \%$ lime slurry was fed to the atomizer at varying rates, corresponding to lime-to- $\mathrm{HCl}$ mole ratios of 2 to 12 . Note that a mole ratio of 2 is four times the theoretical amount of slaked lime required to react with all of the $\mathrm{HCl}$ by the following reaction:

$$
\mathrm{Ca}(\mathrm{OH})_{2}+2 \mathrm{HCl} \rightarrow \mathrm{CaCl}_{2}+2 \mathrm{H}_{2} \mathrm{O}
$$

While the lime slurry flow rate was controlled to vary the molar ratio of slaked lime to $\mathrm{HCl}$, additional water was fed to the atomizer to control the spray dryer outlet temperature at $107^{\circ} \mathrm{C}\left(225^{\circ} \mathrm{F}\right)$. The flue gas entering the spray dryer was at a temperature of $149^{\circ} \mathrm{C}\left(300^{\circ} \mathrm{F}\right)$.

Results from these tests are plotted in Figure 6-7. Note that analysis of the lime slurry indicated that up to $20 \%$ of the lime had degraded to form calcium carbonate. It is likely that the $\mathrm{HCl}$ removal efficiencies could be slightly higher with a purer lime source. However, even with this impurity, $47 \%$ to $82 \%$ of the $\mathrm{HCl}$ was removed from the flue gas as the molar ratio was increased from 2 to 12 . 


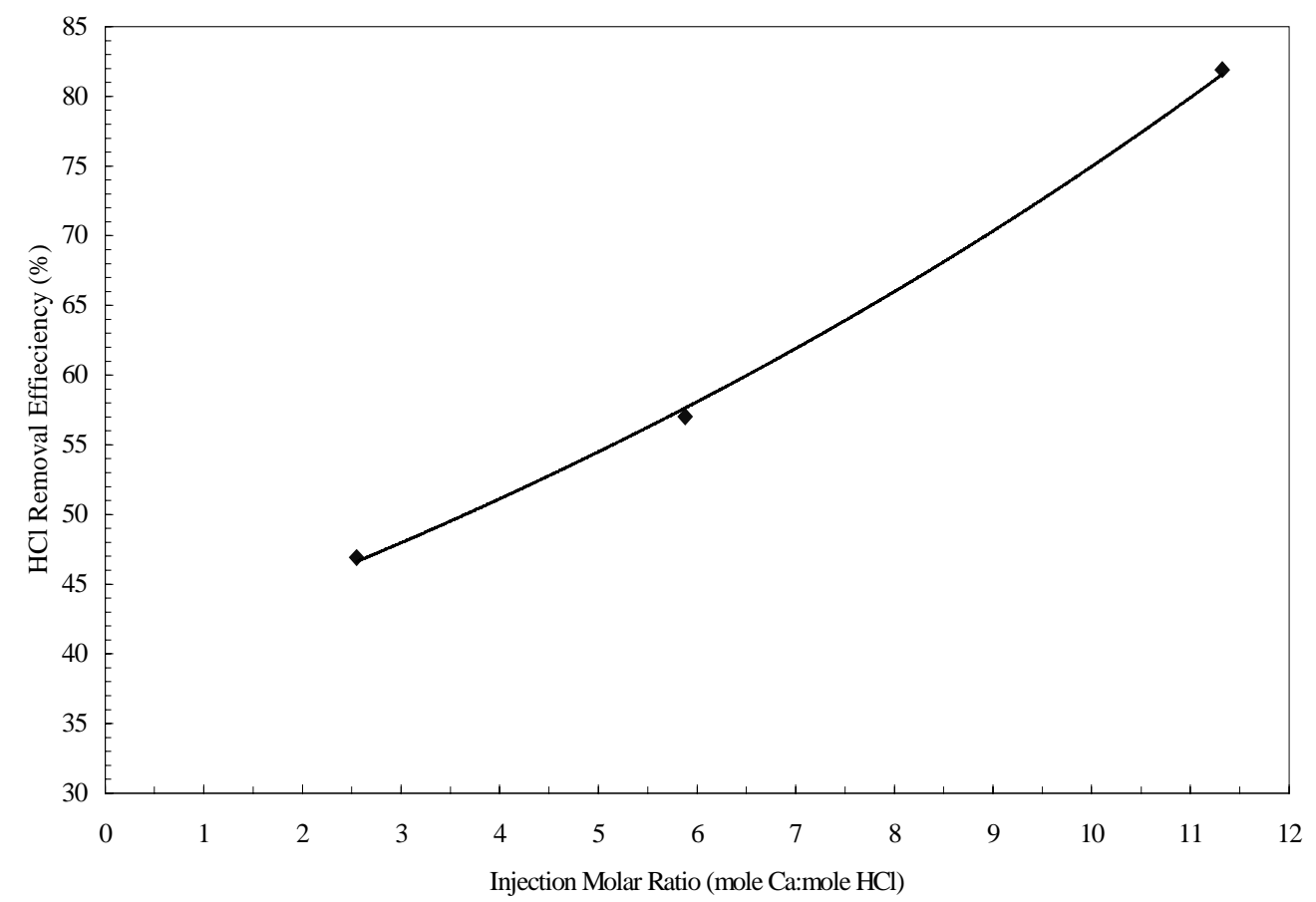

Figure 6-7. Effect of Lime Injection on HCl Removal

In the final test, the spray dryer outlet temperature was cooled to $93^{\circ} \mathrm{C}\left(200^{\circ} \mathrm{F}\right)$ while feeding lime at a 12 molar ratio. The $\mathrm{HCl}$ removal efficiency increased from $82 \%$ to $100 \%$ as the outlet temperature was cooled from $107^{\circ} \mathrm{C}\left(225^{\circ} \mathrm{F}\right)$ to $93^{\circ} \mathrm{C}\left(200^{\circ} \mathrm{F}\right)$. Time and budget constraints ended the chloride removal tests before other conditions could be explored. 


\section{PRELIMINARY MARKET ANALYSIS}

As part of the Phase I project, both Radian and DOE (through a contract with SAIC) performed a preliminary analysis of potential markets for FGD anhydrite. Of the potential uses that differ from gypsum, the most promising markets identified in this initial analysis were the self-leveling floor and aggregate markets. As a follow-up to this initial effort, Radian collected additional information to better define these potential markets. Specific areas investigated included:

- Comparison of our process with the Dutch anhydrite process used to produce material for the European self-leveling floor business;

- Anhydrite properties required for and experiences with self-leveling floors in Europe;

- Anhydrite properties required to penetrate the U.S. self-leveling floor market; and

- The potential for using hardened FGD anhydrite in the U.S. aggregate market.

\section{Comparison with Dutch Anhydrite Process}

Information presented at Ortech's recent International FGD Gypsum Conference indicates that the anhydrite market in The Netherlands and Germany has grown more than 10 -fold in the past 10 years. ${ }^{1}$ We have examined literature provided by DOE (from SAIC), and there are some significant differences between the production of anhydrite by the Dutch process and our FGD solution precipitation method. ${ }^{2,3}$ The Dutch method heats FGD byproduct gypsum to $800^{\circ} \mathrm{C}\left(1472^{\circ} \mathrm{F}\right)$ by a series of cyclones which contact hot gas (produced through combustion of natural gas, oil, or coal) with the gypsum in a countercurrent manner. During the process, the gypsum is first dried, then converted to hemihydrate, and ultimately to anhydrite as the solids reach $800^{\circ} \mathrm{C}\left(1472^{\circ} \mathrm{F}\right)$. The product crystals have a limited internal pore volume, probably as a result of fusion at high temperature. The product anhydrite is pulverized to obtain the desirable fluid properties. The projected cost of this anhydrite is $\$ 66$ per metric ton, f.o.b. the production facility, assuming a delivered cost of gypsum of approximately zero. The preliminary economics for FGD anhydrite (presented later in this section) show the expected cost to be in the $\$ 20$ to $\$ 50$ per ton range.

The process included in the CLS/ anhydrite process should be much more thermally efficient than the Dutch process since the heat of formation is provided almost entirely by the oxidation of the calcium sulfite in the external reactor. This is major advantage since fuel would be expected to be a major operating cost in the Dutch process. (Details 
of projected economics are not presented in the papers.) The anhydrite produced during pilot operations has properties which should make it an acceptable material for self-leveling floor screeds. Canadians have examined a process to produce self-leveling floors from natural anhydrite produced in Nova Scotia. ${ }^{4}$ One successful formulation included addition of ferrous and potassium sulfate (accelerators-about $2 \%$ of the anhydrite binder by weight) and anhydrite ground to a size similar to that measured in solids produced at the ECTC pilot plant (mean size of 20 to $50 \mu \mathrm{m}$.)

A more detailed examination of the production method used in Europe and a comparison with the FGD anhydrite process being developed in this PRDA did not uncover any fatal flaw. The main technical uncertainty initially was the reactivity of the FGD anhydrite product. Material produced in Phase I at the ECTC show that setting and strength properties are similar to the anhydrite used in Europe.

\section{Anhydrite Properties for Self-Leveling Floors}

It was hoped that communications could be held with people involved with this business in Europe. Bill Ellison ${ }^{5}$ recommended that contact be made with Mr. Jantinus Kappe with whom he has co-authored papers. Mr. Ellison said that Mr. Kappe might be difficult to reach since he is often out observing installation of new floors and pursuing new business opportunities. Several attempts to contact Mr. Jantinus Kappe of Kappe Intermediair B.V. in The Netherlands were made to obtain additional information about market development in The Netherlands, but these efforts were unsuccessful. The minimum properties required for anhydrite used in self-leveling floor screeds in The Netherlands (DIN 4208 class AB20) were obtained from one of Mr. Kappe's papers and are as follows:

\begin{tabular}{lc}
\multicolumn{1}{c}{ Property } & Requirement \\
\hline Binding Time & \\
Start (minutes) & 25 \\
Finish (minutes) & 720 \\
\hline 3-day Strength & \\
Bending $\left(\mathrm{N} / \mathrm{mm}^{2}\right)$ & 1.6 \\
Compressive & 8.0 \\
\hline 28-day Strength & \\
Bending $\left(\mathrm{N} / \mathrm{mm}^{2}\right)$ & 4.0 \\
Compressive & 20.0 \\
\hline
\end{tabular}

The best FGD anhydrite produced in their testing had a water-to-gypsum mass ratio of about 0.4 , and a mean particle size of 20 to $30 \mu \mathrm{m}$ (508 to 762 mils) after pulverization. 
Initial indications are that solution generated FGD anhydrite will be able to meet these requirements without addition of additives or modification of product particle size.

Mr. Ellison also said that Krupp Polysius, the manufacturer of the calcination process employed by Mr. Kappe, has sold another calcination process to British Gypsum in the United Kingdom. This is encouraging news which implies that the techniques involved are more widely applicable than just The Netherlands.

\section{Requirements of Anhydrite to Penetrate the Self-Leveling Floor Market in the U.S.}

To follow up on a lead from SAIC, we attempted to make contact with two companies reportedly in or entering the self-leveling floor product business in the U.S., Maxxon Corporation and ARDEX. Unfortunately, contacts with the appropriate parties in either company were not successfully made.

In the search for technical information we were able to obtain specifications for ARDEX SD-T, a self-leveling floor product:

\begin{tabular}{ll} 
Flow Time: & 10 minutes at $21^{\circ} \mathrm{C}\left(70^{\circ} \mathrm{F}\right)$ \\
\hline Initial Set, ASTM C191: & Approximately 15 minutes at $21^{\circ} \mathrm{C}\left(70^{\circ} \mathrm{F}\right)$ \\
\hline Final Set, ASTM C191: & Approximately 60 minutes $21^{\circ} \mathrm{C}\left(70^{\circ} \mathrm{F}\right)$ \\
\hline Compressive Strength, ASTM C109/mod: & $42046 \mathrm{kPa}(6100 \mathrm{psi})$ after 28 days \\
\hline Flexural Strength, ASTM C348: & $8271 \mathrm{kPa}(1200 \mathrm{psi})$ after 28 days \\
\hline
\end{tabular}

From this information, it is apparent that the set times are shorter and final compressive strength is greater than the anhydrite floor specifications used in Europe. This is consistent with information that John Gaynor ${ }^{6}$ of U.S. Gypsum had provided earlier. However, Mr. Gaynor also indicated that a market might be created if anhydrite can be produced cheaply enough. To develop this market, a partnership with companies such as U.S. Gypsum, BPB, Georgia Pacific, LaFarge, and/or ABB will have to be made. Most of these companies have expressed an interest in evaluating anhydrite produced in greater quantities.

\section{Potential for Use of Calcium Sulfate Anhydrite as a Synthetic Aggregate}

The insoluble calcium sulfate anhydrite $\left(\mathrm{CaSO}_{4}\right)$ solids produced as a byproduct from wet lime or limestone FGD systems will, upon rehydration, "set up" to form a coherent, hard mass. This property, which is not characteristic of other byproduct options such as calcium sulfate dihydrate (gypsum), may yield potential market opportunities for the 
anhydrite byproduct option. This section discusses the current production and market situation for aggregates and related construction materials for which this new FGD byproduct could potentially be substituted.

\section{Summary}

In surveying the potential market for anhydrite as a synthetic aggregate, an existing commercial operation was identified in which more than 450,000 metric tons $(500,000$ U.S. tons) per year of anhydrite waste from hydrofluoric acid production is being converted to aggregate and sold as a substitute for crushed stone. This anhydrite product is being used by a number of municipal and county agencies as well as private companies for construction fill and road base material. Assuming that this material has similar properties to those of FGD anhydrite, there appears to be a large potential market for this material in or near urban areas where conventional crushed-stone aggregates are in short supply. In 1993, about 635 million metric tons (700 million U.S. tons) of construction aggregate was sold in the U.S., and this is a use that FGD anhydrite can probably fill and that FGD gypsum cannot.

There does not appear to be any potential for using byproduct anhydrite to produce aggregate for use in concrete. In this use, sulfate is known to react with concrete, causing undesirable expansion and cracking.

\section{Aggregate Production and Use in the United States}

"Aggregate" in the construction industry usually refers a material such as sand, gravel, crushed or uncrushed stone, or various synthetic inorganic materials (e.g., blast furnace slag) that can be used to form the major part of a concrete mixture. The aggregate is an important part of the concrete mix and serves to provide much of its characteristic strength. The term aggregate is also applied to the same types of materials when used in non-concrete applications, for example as road base. In this type of use, an aggregate may be used with or without some type of "binder." Aggregate production and use statistics are compiled in the U.S. Bureau of Mines Minerals Yearbook. ${ }^{7}$ This reference separates aggregate production into the categories of sand and gravel, and crushed stone. The important category for the use of hardened anhydrite is crushed stone.

The 1993 U.S. production of crushed stone amounted to 1.09 billion metric tons (1.2 billion U.S. tons). Of this total production, 30\% was used in unspecified applications. About $83 \%$ of the remaining $70 \%$, or a total of about 635 million metric tons of crushed stone, was used as construction aggregates mostly for road and highway construction. Crushed stone may be produced from a variety of rock or mineral sources. Limestone and dolomite account for about $75 \%$ of the total crushed stone production, with granite, traprock, sandstone, quartzite, and volcanic cinder accounting for most of the remaining production. 
Crushed stone is transported primarily by truck to nearby users. The average value of crushed stone in 1993 was $\$ 5.07 /$ metric ton f.o.b. plant. Similarly, supplies of crushed stone are adequate on a nation-wide basis, but local shortages can occur, providing a market opportunity for qualified synthetic materials.

\section{Contact with Center for Aggregate Research}

The Minerals Yearbook cites the Center for Aggregate Research as a source of information on aggregate markets and use. Dr. Dallas Little at Texas A \& M University was contacted. ${ }^{8}$ Dr. Little said that he is quite familiar with potential use of gypsum byproducts, both dihydrate and anhydrite, as a road-base material. He has consulted with Mobil in Florida about using phospho-gypsum and with both DuPont and Alcoa in Texas about using their fluoro-gypsum (anhydrite) waste. This material is formed during hydrofluoric acid production from fluorspar using sulfuric acid.

Dr. Little recalled that DuPont is currently marketing their waste anhydrite through Gulf States Materials in the LaPorte, Texas area, and said that it makes a pretty good base even unblended. He also said that he had worked with Alcoa in Point Comfort, about using a similar material but that it did not work out because of residual HF in their product. He recalled that the Alcoa material was very hard and coherent and that some samples tested at $24,000 \mathrm{kPa}$ (3500 psi) compressive strength. Their analysis showed that it was a blend of hemihydrate and gypsum as received in their lab.

Dr. Little felt that there are definite market possibilities for this type of material, especially in aggregate-poor locations such as the Houston metropolitan area, for example. He cautioned about using it only for applications where the chemical composition is compatible. It cannot be used along with crushed concrete aggregate, for example, because of sulfate attack. He had also heard second-hand of some soil stabilization uses that had not worked out well.

\section{Contact with Gulf States Materials}

Mr. Dewey Walls, a sales representative with Gulf States Materials in LaPorte, Texas (713) 470-8645 was contacted. ${ }^{9}$ Mr. Walls said that they sell about 450,000 metric tons (500,000 U.S. tons) per year of calcium sulfate aggregate derived from waste produced by DuPont. Their customers include "just about every city and county in the area." The material is also used by oil companies and related businesses as fill, paving, and roadbase.

Gulf States receives the anhydrite as a slurry from DuPont. They "lay it out" and let it set up (Mr. Walls says it "sets up hard as a rock"). Then they scrape it up with a loader and crush and screen it just like a conventional aggregate product. They sell three 
grades: a straight calcium sulfate product, and two different blends, one with $15 \%$ fly ash and one with $6 \%$ cement.

\section{Preliminary Economic Study}

Using the results from the pilot proof-of-concept tests, preliminary economics were developed for a $300 \mathrm{MW}$ power plant (standard for EPRI's FGDCOST model). The results of this study are presented in Tables 7-1 (capital costs) and 7-2 (total operating costs). A 50\% contingency is shown in Table 7-1 because of the early stage of development of this process. The capital costs have been developed assuming that the dewatering system would have to be replaced. In many retrofit situations, the existing filters might be modified, saving a significant capital expense.

Table 7-1. Anhydrite Project Capital Cost Estimate

\begin{tabular}{lccr}
\hline \multicolumn{1}{c}{$\begin{array}{c}\text { Major } \\
\text { Equipment }\end{array}$} & $\begin{array}{c}\text { Materials } \\
\text { Cost }\end{array}$ & $\begin{array}{c}\text { Installed } \\
\text { Cost Factor }\end{array}$ & $\begin{array}{c}\text { Installed } \\
\text { Cost }\end{array}$ \\
\hline Oxidation Air Blowers & $\$ 520,000$ & 3.5 & $\$ 1,820,000$ \\
\hline Anhydrite Reactor with & $\$ 550,000$ & 1.7 & $\$ 935,000$ \\
\hline \multicolumn{1}{c}{ Surface Area Control } & & & \\
\hline Soda Ash System & $\$ 50,000$ & 3.5 & $\$ 175,000$ \\
\hline Centrifuge & $\$ 540,000$ & 3.5 & $\$ 1,890,000$ \\
\hline Dryer & $\$ 340,000$ & 3.5 & $\$ 1,190,000$ \\
\hline Storage Silo & $\$ 1,900,000$ & 1.2 & $\$ 2,280,000$ \\
\hline Major Equipment Delivered & $\$ 3,901,000$ & & $\$ 8,290,000$ \\
\hline Project Engineering & & & $\$ 2,000,000$ \\
\hline Subtotal Capital & & & $\$ 10,290,000$ \\
\hline Contingency & & $50 \%$ & $\$ 5,145,000$ \\
\hline Total Capital Requirement (TCR) & & & $\$ 15,435,000$ \\
\hline
\end{tabular}

Table 7-2. Anhydrite Process Operating Cost Estimate

\begin{tabular}{cccc}
\hline Variable Costs & $\begin{array}{c}\text { Usage/Metric Ton } \\
\text { Anhydrite }\end{array}$ & Cost, \$/Unit & $\begin{array}{c}\text { Cost, \$/ Metric Ton } \\
\text { Anhydrite }\end{array}$ \\
\hline
\end{tabular}




\begin{tabular}{|c|c|c|c|}
\hline Auxiliary power (444 kW) & 52 kWh & $\$ 0.02 / \mathrm{kWh}$ & $\$ 1.15$ \\
\hline Fuel Oil & $170 \mathrm{kWh}$ & $\$ 0.0136 \mathrm{kWh}$ & $\$ 2.56$ \\
\hline Sodium Carbonate & $4.3 \mathrm{~kg}$ & $\$ 0.04 \mathrm{~kg}$ & $\$ 0.84$ \\
\hline Total Variable Costs & & & $\$ 4.55$ \\
\hline Fixed Operating Costs ${ }^{1}$ & \multicolumn{2}{|c|}{$\$ 620,000$} & $\$ 9.24$ \\
\hline Annual Fixed Charges $^{2}$ & \multicolumn{2}{|c|}{$\$ 2,547,000$} & $\$ 37.90$ \\
\hline Total Operating Costs & & & $\$ 52.23$ \\
\hline
\end{tabular}

${ }^{1}$ Maintenance labor and material $=4 \%$ of TCR

${ }^{2}$ Levelized fixed charge is $16.5 \%$ of TCR

The $\$ 52.23$ / metric ton cost of anhydrite is the upper limit of the cost currently expected from the FGD anhydrite process being developed. Without the contingency and the centrifuges (retrofit would use existing dewatering equipment), the cost would drop to about $\$ 33 /$ metric ton. This range compares quite favorably with $\$ 66 /$ metric ton cost for anhydrite for the European process. Additional cost savings may be recognized as the solution precipitation anhydrite process is optimized.

If anhydrite were to be used as aggregate, the dryer, fuel oil, and storage silo would not be required. The cost (without contingency) would be about $\$ 19 /$ metric ton. While this amount is well above the average value of crushed stone aggregate (\$5.07 in 1993), the utility would also avoid calcium sulfite sludge disposal costs if this process were implemented. The cost of disposal typically ranges from $\$ 6$ to $17 /$ metric ton and will increase as regulations for disposal are tightened. Credit for $\$ 6$ to $\$ 17 /$ metric ton in avoided disposal cost if saleable aggregate is produced could make this option attractive to some utilities.

${ }^{1}$ Nijman, G., "Anhydrite from FGD Gypsum: The Ultimate Binder for Self-Leveling Floor Screeds," presented at the Fifth International Conference on FGD and Synthetic Gypsum, May 11-14, 1997, Toronto Canada.

${ }^{2}$ Kappe, J., "High Quality Anhydrite from Flue Gas Desulphuization Gypsum," Environment and Technology, November 1991.

${ }^{3}$ Kappe, J., L. Moonen, and W. Ellison, "Growth in By-Product Gypsum Yield/Use for Floor Screeds," unknown source.

4 “Anhydrite Self-Leveling Flooring Screed: Final Report,” Microlog (233440-1-9044-01-SQ.)

${ }^{5}$ Telephone contact with Mr. William Ellison, Ellison Consultants, Monrovia, Maryland (301) 8655302 , October 3, 1996. 
${ }^{6}$ Telephone conversation with Mr. John Gaynor, Technical Manager, U.S. Gypsum Company, Chicago, Illinois, (312) 606 3735, August 20, 1996.

${ }^{7}$ Minerals Yearbook, Volume 1, Metals and Minerals, U.S. Department of Interior, Bureau of Mines, Washington DC, 1993.

${ }^{8}$ Telephone Contact with Dr. Dallas Little, Center for Aggregate Research, Texas, A \& M University, College Station, Texas, (409) 845-9847, October 1, 1996.

${ }^{9}$ Telephone Contact with Dewey Walls, sales representative, Gulf States Materials, LaPorte, Texas, (713) 470-8645, October 1, 1996. 


\section{8}

\section{FUTURE DEVELOPMENT NEEDS}

Phase I proof-of-concept activities proved that anhydrite can be successfully precipitated directly from solution using calcium sulfite feed slurry from an FGD system. Preliminary testing of small quantities of material indicate that the anhydrite can be used both in self-leveling floors and as construction aggregate. Additional work is required to optimize the process, identify the most effective control system and monitoring requirements, demonstrate performance at the pilot scale, collect sufficient quantities of product for end-user evaluation, and test the product qualities for the different markets. As part of the Phase I effort, a future development approach has been designed to accomplish these objectives and is discussed here.

In this future development effort, lab-scale equipment would first be used to provide a better understanding of process monitoring requirements, to optimize anhydrite production performance, and to establish appropriate process control strategies. Following this lab-scale effort, pilot-scale testing should be conducted to demonstrate integrated operation of the process. The integrated testing should include an anhydrite reactor of appropriate height-to-diameter ratio based on lab-scale results, and should include provisions for anhydrite product washing and drying. The latter would allow larger-scale testing of the product by potential end users. The pilot unit would ideally be located at the site of a host utility that is interested in commercializing the process.

The remainder of this section further describes this future development approach, including lab-scale activities, pilot testing, and commercialization activities.

\section{Lab-Scale Activities}

The first task in the laboratory would be to experimentally determine equilibrium conditions for gypsum saturation at conditions of interest for anhydrite production. As explained in the anhydrite process discussion in Section 4 and as shown graphically in Figure 4-2, the anhydrite process should operate with a gypsum relative saturation slightly below one. This would allow the largest driving force for anhydrite production without forming gypsum. However, the concentrated nature of the reactor solution makes the determination of the relative saturation difficult. Calculational approaches for determining relative saturation are typically not accurate at the high solution ionic strength levels required for optimum anhydrite production. Therefore a series of equilibrium tests would be conducted covering a range of temperatures and compositions anticipated for anhydrite production. These data would then be used to 
calibrate a computer model that has been developed to calculate thermodynamic properties of solutions from their chemical analyses. High ionic strength solutions would be equilibrated with excess gypsum at specific temperatures for several hours and the resulting solutions would be analyzed to determine the final chemical compositions. Under these conditions, the gypsum relative saturation in solution should be equal to one. The chemical analyses would be entered into the equilibrium program to determine the calibration corrections necessary to correctly calculate the relative saturation.

A second series of lab-scale tests would be conducted in a well-stirred mixed suspension, mixed product removal (MSMPR) reactor. This reactor is essentially a smaller version of the pilot reactor. A few variables, such as air rate required for complete oxidation, cannot directly be scaled up, but the kinetics of the reactions can be. A wider range of operating conditions can be examined for less cost at this scale than at the pilot scale. Once the optimum conditions have been established at the bench, a pilotscale system could be designed and tested for confirmation and to determine if there are longer term operability and control issues.

A series of laboratory parametric tests would be conducted to evaluate the possible operating envelope for the anhydrite process. In these tests, calcium sulfite solids would be oxidized in the reactor to simulate the commercial process. (This differs from the flow-through liquid, batch solids tests in Phase I that allowed an even wider range of variables to be examined in a shorter time period.)

The experimental approach would be based on a partial factorial design around a central point. In general, first and second order effects can be identified with a partial factorial design, but second order variable interactions cannot. Since a full factorial analysis would require more than 100 tests, this test approach is a reasonable compromise. Subsequent pilot testing would provide additional evaluation of the more favorable conditions.

\section{Pilot Activities}

Following the completion of lab-scale MSMPR reactor tests, sufficient information should be available to allow an optimized, pilot-scale anhydrite reactor to be designed and constructed. An ideal location for such a pilot reactor would be adjacent to an existing full-scale, sulfite-producing FGD system operated by a utility that is interested in anhydrite production. A portion of the blowdown slurry from this operating FGD system would serve as the feed to the reactor.

Selected conditions would be tested on this pilot reactor to demonstrate the ability to maintain successful production of anhydrite through typical operating variations including startup from a cold condition and shutdown. During these confirmation tests, a set of monitoring measurements would be developed to provide a means of 
controlling the process. Test durations of several weeks at each condition would be needed to accomplish these goals. A series of 10-to 20-day runs would be anticipated.

There would be several changes made from the way that Phase I tests were conducted at the ECTC to make the tests more meaningful and less costly. First, based on the results from Phase I and subsequent lab-scale testing, a reactor would be built to provide the desired residence time while providing the necessary slurry level for oxidation with low air rates. This would allow operation at residence times required for economical commercial operation without excessive heat input requirements during pilot testing. A second equipment modification would be to provide for hot water wash on a belt filter dewatering device. This would allow wash efficiency (to remove either sodium or magnesium) to be evaluated without converting the product to gypsum by exposure to cold water on the belt. Finally, a drier would be included so that several hundred pounds per day of product could be produced for testing by interested parties. During Phase I, only about 2 pounds per day could be dried effectively and this product contained residual sodium because of the direct collection of product in alcohol without washing first.

For analytical support, only critical measurements such as percent bound water, $\mathrm{pH}$, temperature, and sodium or magnesium concentration would be monitored frequently on site. Other analyses would be sent to Radian's Austin laboratories for processing. These changes should provide a more thorough, but cost-effective evaluation of the process.

\section{Commercialization Activities}

A number of potential end users including ABB Environmental Services, BPB Gypsum, G-P Gypsum, LaFarge, and U.S. Gypsum have done a preliminary examination of the anhydrite product produced in Phase I. Several have requested more material for testing and have expressed a willingness to continue evaluation (see BPB/Westroc letter in Appendix A). Ultimately, for anhydrite to be commercialized in the self-leveling floor or plaster business, a partnership would have to be formed with one or more of these companies.

In addition to its use in the plaster business, testing of hardened anhydrite for use as construction aggregate should be performed. Dr. Dallas Little of the Center for Aggregate Research, Texas A\&M University, would be a suitable candidate to perform appropriate ASTM and other tests to demonstrate product suitability for aggregate use. These results would be necessary to convince utilities in aggregate poor areas to enter this market. Samples should also be sent to Gulf Materials to solicit input from a commercial aggregate supplier of similar material. 
Future Development Needs

As part of the commercialization activities, a more detailed process cost estimate should be prepared to assist in the commercialization decision. 
A

LETTERS FROM INTERESTED COMPANIES 
Letters from Interested Companies

A-2 



\section{B}

\section{ANHYDRITE OPERATIONS AND RESULTS SUMMARY}

\section{Table B-1. Anhydrite Operations and Results Summary}

\begin{tabular}{|c|c|c|c|c|c|c|c|}
\hline Date & $\begin{array}{c}\text { Test ID/ } \\
\text { Description }\end{array}$ & Operating/Results Summary & $\begin{array}{c}\text { Sample } \\
\text { ID }^{1}\end{array}$ & $\begin{array}{l}\text { Solid } \\
\text { Wt \% } \\
\text { Hydrate }\end{array}$ & $\begin{array}{c}\text { Est. } \\
\text { Wt \% } \\
\text { Anhydrite }\end{array}$ & $\begin{array}{c}\text { SEM } \\
\text { Description }\end{array}$ & $\begin{array}{c}\text { XRD } \\
\text { Description }\end{array}$ \\
\hline Fri, 1/5 & ANH-0: Startup & $\begin{array}{l}\text { Operations began to build sulfite solids } \\
\text { in the FGD reaction tank (FGDRT). } \mathrm{pH} \\
\text { maintained at } 5.5 \text { with limestone. }\end{array}$ & & & & & \\
\hline $\begin{array}{l}\text { Sat-Mon, } \\
1 / 4-1 / 6\end{array}$ & $\mathrm{ANH}-\mathrm{O}$ & $\begin{array}{l}\text { Continue to build solids in the FGDRT. } \\
\text { The inlet } \mathrm{SO}_{2} \text { concentration and liquid } \\
\text { recirculation rate were increased } \\
\text { temporarily to build solids more quickly. }\end{array}$ & & & & & \\
\hline Tue, 1/7 & $\mathrm{ANH}-\mathrm{O}$ & $\begin{array}{l}\text { The FGDRT solids concentration is up to } \\
20 \text { wt \% with a mixture of sulfite and } \\
\text { gypsum. The thiosulfate concentration } \\
\text { was increased by adding elemental } \\
\text { sulfur. Lime slurry was fed to the SDA to } \\
\text { reduce the inlet } \mathrm{HCl} \text {. }\end{array}$ & & & & & \\
\hline Wed, $1 / 8$ & $\mathrm{ANH}-\mathrm{O}$ & $\begin{array}{l}\text { Began transferring FGDRT slurry to the } \\
\text { anhydrite reaction tank (ART). ART } \\
\text { slurry was pumped through heated coils } \\
\text { at about } 0.63 \mathrm{~L} / \mathrm{s}(10 \mathrm{gpm}) \text {. The SDA } \\
\text { atomizer tripped. Both spindles were } \\
\text { sent to be repaired. }\end{array}$ & & & & & \\
\hline Thu, 1/9 & $\mathrm{ANH}-\mathrm{O}$ & $\begin{array}{l}\text { The ART slurry temperature increased } \\
\text { from } 33^{\circ} \mathrm{C} \text { to } 11^{\circ} \mathrm{C} \text { below baseline } \\
\text { temperature overnight. Oxidation air was } \\
\text { started in the } \mathrm{ART} \text { at } 331 \mathrm{Nm}^{3} / \mathrm{h}(220 \\
\mathrm{scfm})\left(\mathrm{O}: \mathrm{SO}_{2}=6\right) \text {. The temperature } \\
\text { began to drop, and the } \mathrm{pH} \text { was } 1.3 \text { units } \\
\text { above baseline } \mathrm{pH} \text {. Some additive } 1 \text { was } \\
\text { added to reduce the } \mathrm{pH} \text { but not enough } \\
\text { was available to reach a target } \mathrm{pH} \text { of } 0.2 \\
\text { units above baseline. The oxidation air } \\
\text { rate was increased to } 496 \mathrm{Nm}^{3} / \mathrm{h}(330 \\
\text { scfm). Slurry was sent from the ART to } \\
\text { the vacuum belt filter that evening. }\end{array}$ & & & & & \\
\hline
\end{tabular}

${ }^{1} \mathrm{SEM}, \mathrm{XRD}$, and/or EDX analyses are available for samples shown in bold. 
Table B-1. Anhydrite Operations and Results Summary

\begin{tabular}{|c|c|c|c|c|c|c|c|}
\hline Date & $\begin{array}{c}\text { Test ID/ } \\
\text { Description }\end{array}$ & Operating/Results Summary & $\begin{array}{c}\text { Sample } \\
\text { ID }^{1}\end{array}$ & $\begin{array}{c}\text { Solid } \\
\text { Wt \% } \\
\text { Hydrate }\end{array}$ & $\begin{array}{c}\text { Est. } \\
\text { Wt \% } \\
\text { Anhydrite }\end{array}$ & $\begin{array}{c}\text { SEM } \\
\text { Description }\end{array}$ & $\begin{array}{c}\text { XRD } \\
\text { Description }\end{array}$ \\
\hline Fri, $1 / 10$ & $\mathrm{ANH}-0$ & $\begin{array}{l}\text { Solids sent to the vacuum belt had poor } \\
\text { dewatering characteristics so the } \\
\text { centrifuge was used. The solid sulfite } \\
\text { concentration in the ART was still } \\
\text { relatively high but lower than that in the } \\
\text { FGDRT, indicating complete oxidation } \\
\text { had not yet been achieved. The ART } \\
\text { temperature had decreased to } 30^{\circ} \mathrm{C} \\
\text { below baseline temperature. }\end{array}$ & & & & & \\
\hline $\begin{array}{l}\text { Sat-Sun, } \\
1 / 11-1 / 12\end{array}$ & ANH-O & $\begin{array}{l}\text { Slurry was continuously sent from the } \\
\text { FGDRT to the ART, and slurry from the } \\
\text { ART was dewatered using the } \\
\text { centrifuge. }\end{array}$ & & & & & \\
\hline Mon, $1 / 13$ & $\mathrm{ANH}-0$ & $\begin{array}{l}\text { Solids oxidation remained low in the } \\
\text { ART, and the pH remained high. Slurry } \\
\text { blowdown from the FGDRT to the ART } \\
\text { was stopped, and the oxidation air rate } \\
\text { was lowered to } 331 \mathrm{Nm}^{3} / \mathrm{h}(220 \mathrm{scfm}) \text { to } \\
\text { try to convert the ART solids to } \\
\text { anhydrite/gypsum. After reducing the air } \\
\text { rate, the ART temperature increased to } \\
28^{\circ} \mathrm{C} \text { below baseine. }\end{array}$ & & & & & \\
\hline Tue, $1 / 14$ & $\mathrm{ANH}-0$ & $\begin{array}{l}\text { The ART pH was lowered to } 0.2 \text { units } \\
\text { above baseline by adding additive } 1 \text {. The } \\
\text { ART was oxidized closed-loop (i.e., no } \\
\text { slurry blowdown) overnight. }\end{array}$ & & & & & \\
\hline Wed, $1 / 15$ & $\mathrm{ANH}-0$ & $\begin{array}{l}\text { The ART solids concentration is about } \\
23 \mathrm{wt} \% \text {, and the solids are } 85 \% \\
\text { oxidized. The temperature has increased } \\
\text { to } 15^{\circ} \mathrm{C} \text { below baseline. }\end{array}$ & & & & & \\
\hline Thu, $1 / 16$ & $\mathrm{ANH}-0$ & $\begin{array}{l}\text { The ART was insulated. Throughout the } \\
\text { early morning, the ART was closed-loop } \\
\text { oxidized. By morning samples, the pH } \\
\text { had decreased to } 1.6 \text { units below } \\
\text { baseline pH and the temperature was } \\
\text { decreasing. The solids were fully } \\
\text { oxidized. Slurry addition from the } \\
\text { FGDRT to the ART was started. As } \\
\text { slurry was added, the pH and } \\
\text { temperature would rise. However, if } \\
\text { FGDRT slurry flow was stopped, the pH } \\
\text { and temperature would immediately } \\
\text { decrease. With oxidation complete, } \\
\text { slurry addition was required to maintain } \\
\text { the desired pH and temperature. In the } \\
\text { evening, NYSEG shutdown. Although } \\
\text { flue gas was not available, the large } \\
\text { FGDRT volume allowed continued slurry } \\
\text { feed from the FGDRT to the ART. }\end{array}$ & $\mathrm{T}-42$ & 15.4 & 25 & & \\
\hline
\end{tabular}


Table B-1. Anhydrite Operations and Results Summary

\begin{tabular}{|c|c|c|c|c|c|c|c|}
\hline Date & $\begin{array}{c}\text { Test ID/ } \\
\text { Description } \\
\end{array}$ & Operating/Results Summary & $\begin{array}{c}\text { Sample } \\
\text { ID }^{1}\end{array}$ & $\begin{array}{c}\text { Solid } \\
\text { Wt \% } \\
\text { Hydrate }\end{array}$ & $\begin{array}{c}\text { Est. } \\
\text { Wt \% } \\
\text { Anhydrite }\end{array}$ & $\begin{array}{c}\text { SEM } \\
\text { Description }\end{array}$ & $\begin{array}{c}\text { XRD } \\
\text { Description }\end{array}$ \\
\hline Fri, $1 / 17$ & $\mathrm{ANH}-\mathrm{O}$ & $\begin{array}{l}\text { Oxidation air was temporarily lost in the } \\
\text { morning when NYSEG went offline. The } \\
\text { pH increased to } 1.0 \text { units above the } \\
\text { baseline } \mathrm{pH} \text {, and the temperature was } \\
\text { about } 9^{\circ} \mathrm{C}\left(16^{\circ} \mathrm{F}\right) \text { below the baseline } \\
\text { temperature. Flow through the heated } \\
\text { coil was also lost temporarily. A second } \\
\text { heated coil was added, and flow through } \\
\text { both coils was eventually started. The } \\
\text { ART level was allowed to rise by } \\
\text { stopping slurry blowdown to the vacuum } \\
\text { belt, and the oxidation air rate was } \\
\text { reduced from } 240 \mathrm{Nm} / \mathrm{h}(160 \mathrm{scfm}) \text { to } \\
180 \mathrm{Nm}^{3} / \mathrm{h}(120 \mathrm{scfm}) \text {. The oxidation air } \\
\text { rate was reduced further as the ART } \\
\text { level rose to maintain } \mathrm{pH} \text {. }\end{array}$ & $\begin{array}{l}\mathrm{T}-50 \\
\mathrm{~T}-48\end{array}$ & $\begin{array}{l}18.3 \\
19.9\end{array}$ & $\begin{array}{c}11 \\
3\end{array}$ & & \\
\hline Sat, $1 / 18$ & $\mathrm{ANH}-0$ & $\begin{array}{l}\text { The ART temperature was } 6^{\circ} \mathrm{C}\left(11^{\circ} \mathrm{F}\right) \\
\text { below baseline. Flow to one coil was } \\
\text { stopped due to pluggage. In the evening, } \\
\text { the FGDRT level dropped below the } \\
\text { agitator since NYSEG was still down. } \\
\text { Therefore, slurry was no longer fed to } \\
\text { the ART, and the pH dropped to } 1.1 \\
\text { units below baseline. Soda ash was } \\
\text { added to increase the pH to } 0.2 \text { units } \\
\text { above baseline } \mathrm{pH} \text {. }\end{array}$ & T-56 & 21.0 & 0 & & \\
\hline Sun, $1 / 19$ & $\mathrm{ANH}-0$ & $\begin{array}{l}\text { In late afternoon, NYSEG restarted and } \\
\text { building solids in the FGDRT began. The } \\
\text { ART was continuously recycled through } \\
\text { the heated coils, and the temperature } \\
\text { was about } 19^{\circ} \mathrm{C}\left(35^{\circ} \mathrm{F}\right) \text { below the } \\
\text { baseline temperature. }\end{array}$ & & & & & \\
\hline Mon, $1 / 20$ & $\mathrm{ANH}-0$ & $\begin{array}{l}\text { Continue to build FGDRT solids with no } \\
\text { slurry feed to the ART. }\end{array}$ & $\begin{array}{l}\mathrm{T}-59 \\
\mathrm{~T}-63\end{array}$ & $\begin{array}{l}20.5 \\
18.1\end{array}$ & $\begin{array}{c}0 \\
12\end{array}$ & & \\
\hline Tue, $1 / 21$ & $\mathrm{ANH}-\mathrm{O}$ & $\begin{array}{l}\text { The ART temperature had fallen to } 28^{\circ} \mathrm{C} \\
\left(50^{\circ} \mathrm{F}\right) \text { below baseline due to a tripped } \\
\text { heater in the heated water tank. Two } \\
\text { new heated coils were installed to } \\
\text { replace the old ones. Slurry from the } \\
\text { ART was sent to the vacuum belt to } \\
\text { reduce the solids concentration. The } \\
\text { lines to the pH tree and vacuum belt } \\
\text { plugged frequently. }\end{array}$ & $\begin{array}{l}\text { T-65 } \\
\text { T-69 }\end{array}$ & $\begin{array}{l}17.3 \\
18.6\end{array}$ & $\begin{array}{c}15 \\
9\end{array}$ & & \\
\hline Wed, $1 / 22$ & $\mathrm{ANH}-0$ & $\begin{array}{l}\text { With both coils operated in series, the } \\
\text { ART temperature was } 19^{\circ} \mathrm{C}\left(35^{\circ} \mathrm{F}\right) \text { below } \\
\text { baseline with no slurry feed from the } \\
\text { FGDRT. The coils were rearranged in a } \\
\text { parallel configuration so that about } 1.9 \\
\mathrm{~L} / \mathrm{s}(30 \mathrm{gpm}) \text { could be sent through the } \\
\text { coils. Slurry from the FGDRT was fed to } \\
\text { the ART. The temperature eventually } \\
\text { reached } 3^{\circ} \mathrm{C}\left(6^{\circ} \mathrm{F}\right) \text { below baseline } \\
\text { temperature. The oxidation air rate was } \\
\text { reduced to } 45 \mathrm{Nm}^{3} / \mathrm{h}(30 \text { scfm) to keep } \\
\text { the feed rate to the ART under } 0.13 \mathrm{~L} / \mathrm{s} \\
(2 \mathrm{gpm}) \text {. }\end{array}$ & $\mathrm{T}-75$ & 19.0 & 7 & & \\
\hline
\end{tabular}


Table B-1. Anhydrite Operations and Results Summary

\begin{tabular}{|c|c|c|c|c|c|c|c|}
\hline Date & $\begin{array}{c}\text { Test ID/ } \\
\text { Description }\end{array}$ & Operating/Results Summary & $\begin{array}{c}\text { Sample } \\
\text { ID }^{1}\end{array}$ & $\begin{array}{c}\text { Solid } \\
\text { Wt \% } \\
\text { Hydrate }\end{array}$ & $\begin{array}{c}\text { Est. } \\
\text { Wt \% } \\
\text { Anhydrite }\end{array}$ & $\begin{array}{c}\text { SEM } \\
\text { Description }\end{array}$ & $\begin{array}{c}\text { XRD } \\
\text { Description }\end{array}$ \\
\hline Thu, $1 / 23$ & $\begin{array}{l}\text { ANH-1: First } \\
\text { attempt to make } \\
\text { anhydrite. Avg. } \\
\text { ART conditions: } \\
\text { baseline } \\
\text { temperature, } 28 \\
\text { wt \% solids ( } 91 \mathrm{hr} \\
\text { residence time), } \\
1.2 \mathrm{M} \mathrm{Na} \text {, } \\
\text { baseline } \mathrm{pH}\end{array}$ & $\begin{array}{l}\text { The ART temperature reached baseline. } \\
\text { With the temperature now high enough, } \\
\text { the first anhydrite test began. The } \mathrm{HCl} \\
\text { analyzer was operational, and lime was } \\
\text { injected in the SDA to reduce the } \mathrm{HCl} \\
\text { concentration to about } 25 \mathrm{ppm} \text {. }\end{array}$ & $\begin{array}{l}\mathrm{T}-77 \\
\mathrm{~T}-81\end{array}$ & $\begin{array}{l}20.2 \\
18.2\end{array}$ & $\begin{array}{c}1 \\
11\end{array}$ & & \\
\hline Fri, $1 / 24$ & $\begin{array}{l}\text { ANH-1: Avg. ART } \\
\text { conditions: } \\
\text { baseline } \\
\text { temperature, } 28 \\
\text { wt \% solids ( } 91 \mathrm{hr} \\
\text { residence time), } \\
1.2 \mathrm{M} \mathrm{Na} \text {, } \\
\text { baseline } \mathrm{pH}\end{array}$ & $\begin{array}{l}\text { The afternoon ART sample indicated } \\
14 \% \text { moisture in the solids or about } 30 \% \\
\text { anhydrite. The heated coils were lost } \\
\text { temporarily due to a leak. The ART } \\
\text { temperature never dropped lower than } \\
1^{\circ} \mathrm{C}\left(3^{\circ} \mathrm{F}\right) \text { below baseline. Some very } \\
\text { hard deposits had formed on the vacuum } \\
\text { belt preventing it from working properly. } \\
\text { Operation switched to the centrifuge. }\end{array}$ & $\begin{array}{l}\mathrm{T}-83 \\
\mathrm{~T}-89\end{array}$ & $\begin{array}{l}14.7 \\
14.0\end{array}$ & $\begin{array}{l}28 \\
32\end{array}$ & & \\
\hline $\begin{array}{l}\text { Sat-Sun, } \\
1 / 25-1 / 26\end{array}$ & $\begin{array}{l}\text { ANH-1: Avg. ART } \\
\text { conditions: } \\
\text { baseline } \\
\text { temperature, } 28 \\
\text { wt } \% \text { solids ( } 91 \mathrm{hr} \\
\text { residence time), } \\
1.2 \mathrm{M} \mathrm{Na} \text {, } \\
\text { baseline } \mathrm{pH}\end{array}$ & $\begin{array}{l}\text { The unit ran well over the weekend with } \\
\text { the ART temperature never dropping } \\
\text { below the baseline temperature. } \\
\text { However, the vacuum belt } \\
\text { filter/centrifuge had problems. }\end{array}$ & & & & & \\
\hline Mon, 1/27 & $\begin{array}{l}\text { ANH-1: Avg. ART } \\
\text { conditions: } \\
\text { baseline } \\
\text { temperature, } 28 \\
\text { wt } \% \text { solids ( } 91 \mathrm{hr} \\
\text { residence time), } \\
1.2 \mathrm{M} \mathrm{Na} \text {, } \\
\text { baseline } \mathrm{pH}\end{array}$ & $\begin{array}{l}\text { The morning ART solid sample indicated } \\
9.6 \% \text { moisture or about } 50 \% \text { anhydrite. } \\
\text { The sludge bin solids are hard. Solids } \\
\text { were sent to the thickener underflow } \\
\text { storage tank temporarily while the } \\
\text { vacuum belt filter cloth was replaced. A } \\
\text { hot-water wash line was installed. Lime } \\
\text { addition plugged the SDA duct so gas } \\
\text { flow was redirected to bypass the SDA. }\end{array}$ & T-91 & 9.6 & 53 & & \\
\hline Tue, $1 / 28$ & $\begin{array}{l}\text { ANH-1: Avg. ART } \\
\text { conditions: } \\
\text { baseline } \\
\text { temperature, } 28 \\
\text { wt \% solids ( } 91 \mathrm{hr} \\
\text { residence time), } \\
1.2 \mathrm{M} \mathrm{Na} \text {, } \\
\text { baseline } \mathrm{pH}\end{array}$ & $\begin{array}{l}\text { The ART temperature was } 3^{\circ} \mathrm{C}\left(5^{\circ} \mathrm{F}\right) \\
\text { above baseline, and the solids were } \\
\text { about } 45 \% \text { anhydrite in the morning. The } \\
\text { afternoon sample indicated only } 27 \% \\
\text { anhydrite. The vacuum belt was } \\
\text { restarted, and the solids came off the } \\
\text { cloth easily. The centrifuge was used to } \\
\text { dewater the slurry accumulated in the } \\
\text { thickener underflow storage tank. }\end{array}$ & $\begin{array}{l}\mathrm{T}-97 \\
\mathrm{~T}-101\end{array}$ & $\begin{array}{l}11.2 \\
14.9\end{array}$ & $\begin{array}{l}45 \\
27\end{array}$ & & \\
\hline Wed, $1 / 29$ & $\begin{array}{l}\text { ANH-1: Avg. ART } \\
\text { conditions: } \\
\text { baseline } \\
\text { temperature, } 28 \\
\text { wt } \% \text { solids ( } 91 \mathrm{hr} \\
\text { residence time), } \\
1.2 \mathrm{M} \mathrm{Na} \text {, } \\
\text { baseline } \mathrm{pH}\end{array}$ & $\begin{array}{l}\text { Solids were settling very quickly in the } \\
\text { lines to the heated coils causing } \\
\text { problems. The morning ART sample } \\
\text { showed about } 28 \% \text { anhydrite. To } \\
\text { increase the anhydrite percentage, test } \\
\text { conditions were changed by lowering the } \\
\text { feed rate from the FGDRT to the ART } \\
\text { from } 0.10 \mathrm{~L} / \mathrm{s}(1.6 \mathrm{gpm}) \text { to } 0.06 \text { ( } 1.0 \\
\text { gpm). The vacuum belt filter cloth } \\
\text { blinded again so the centrifuge was } \\
\text { used. }\end{array}$ & $\mathrm{T}-103$ & 14.8 & 28 & & \\
\hline
\end{tabular}


Table B-1. Anhydrite Operations and Results Summary

\begin{tabular}{|c|c|c|c|c|c|c|c|}
\hline Date & $\begin{array}{c}\text { Test ID/ } \\
\text { Description }\end{array}$ & Operating/Results Summary & $\begin{array}{c}\text { Sample } \\
\text { ID }^{1}\end{array}$ & $\begin{array}{c}\text { Solid } \\
\text { Wt \% } \\
\text { Hydrate }\end{array}$ & $\begin{array}{c}\text { Est. } \\
\text { Wt \% } \\
\text { Anhydrite }\end{array}$ & $\begin{array}{c}\text { SEM } \\
\text { Description }\end{array}$ & $\begin{array}{c}\text { XRD } \\
\text { Description }\end{array}$ \\
\hline Thu,. 1/30 & $\begin{array}{l}\text { ANH-2: Same as } \\
\text { ANH-1 but with a } \\
\text { lower ART feed } \\
\text { rate. Avg. ART } \\
\text { conditions: } \\
\text { baseline } \\
\text { temperature, } 29 \\
\text { wt } \% \text { solids, } 1.1 \mathrm{M} \\
\mathrm{Na} \text {, baseline pH }\end{array}$ & $\begin{array}{l}\text { In the early morning, the ART } \mathrm{pH} \\
\text { increased to } 1.4 \text { units above baseline } \\
\text { despite the lower feed rate from the } \\
\text { FGDRT. The ART temperature dropped } \\
\text { to } 16^{\circ} \mathrm{C}\left(30^{\circ} \mathrm{F}\right) \text { below baseline. It } \\
\text { appeared oxidation was lost, possibly } \\
\text { due to a plugged sparge ring. The } \\
\text { oxidation air rate was increased to } 225 \\
\left.\mathrm{Nm}^{3} / \mathrm{h} \text { ( } 150 \mathrm{scfm}\right) \text {, and additive } 1 \text { was } \\
\text { added to reduce the pH. When the ART } \\
\text { pH reached } 0.5 \text { units above baseline, the } \\
\text { pH dropped quickly to } 0.6 \text { units below } \\
\text { baseline. The oxidation air rate was } \\
\text { reduced to } 45 \mathrm{Nm} / \mathrm{h}(30 \mathrm{scfm}) \text {. Morning } \\
\text { samples indicated } 100 \% \text { oxidation } \\
\text { despite the problems. The oxidation air } \\
\text { heater was operational by mid-afternoon } \\
\text { and operated at } 121^{\circ} \mathrm{C}\left(250^{\circ} \mathrm{F}\right) \text {. } \\
\text { Throughout the evening, the pH } \\
\text { remained over } 0.2 \text { units above baseline } \\
\text { despite decreasing the } \mathrm{ART} \text { feed to } \\
0.057 \mathrm{~L} / \mathrm{s}(0.9 \mathrm{gpm}) \text {. The oxidation air } \\
\text { rate was increased to } 60 \mathrm{Nm}^{3} / \mathrm{h} \text { ( } 40 \\
\text { scfm). }\end{array}$ & $\begin{array}{l}\mathrm{T}-109 \\
\mathrm{~T}-113\end{array}$ & $\begin{array}{l}19.7 \\
20.2\end{array}$ & $\begin{array}{l}4 \\
2\end{array}$ & & \\
\hline Fri, $1 / 31$ & $\begin{array}{l}\text { ANH-2: Same as } \\
\text { ANH-1 but with a } \\
\text { lower ART feed } \\
\text { rate. Avg. ART } \\
\text { conditions: } \\
\text { baseline } \\
\text { temperature, } 29 \\
\text { wt \% solids, } 1.1 \mathrm{M} \\
\mathrm{Na} \text {, baseline } \mathrm{pH}\end{array}$ & $\begin{array}{l}\text { The ART temperature is within one } \\
\text { degree of baseline. The oxidation air } \\
\text { heater is operating at } 177^{\circ} \mathrm{C}\left(350^{\circ} \mathrm{F}\right) \text { with } \\
\text { water added before and after the heater. } \\
\text { The } \mathrm{pH} \text { is still higher than expected with } \\
60 \mathrm{Nm}^{3} / \mathrm{h}(40 \mathrm{scfm}) \text { air. The air sparger } \\
\text { may be partially plugged. However, the } \\
\text { FGDRT pH has been slightly higher at } \\
5.7 \text {. This pH is being lowered to } 5.5 \text { to } \\
\text { see if that helps reduce the ART pH. }\end{array}$ & $\begin{array}{l}\mathrm{T}-115 \\
\mathrm{~T}-119\end{array}$ & $\begin{array}{l}20.2 \\
20.7\end{array}$ & $\begin{array}{c}1 \\
-1\end{array}$ & & \\
\hline Sat, $2 / 1$ & $\begin{array}{l}\text { ANH-2: Same as } \\
\text { ANH-1 but with a } \\
\text { lower ART feed } \\
\text { rate. Avg. ART } \\
\text { conditions: } \\
\text { baseline } \\
\text { temperature, } 29 \\
\text { wt } \% \text { solids, } 1.1 \mathrm{M} \\
\mathrm{Na} \text {, baseline } \mathrm{pH} \\
\end{array}$ & $\begin{array}{l}\text { The ART temperature is } 3^{\circ} \mathrm{C}\left(5^{\circ} \mathrm{F}\right) \text { above } \\
\text { baseline. However, the ART } \mathrm{pH} \text { is still } \\
\text { higher than expected with } 60 \mathrm{Nm}^{3} / \mathrm{h}(40 \\
\text { scfm) air. Therefore, the ART slurry was } \\
\text { transferred to a hold tank to inspect the } \\
\text { ART sparge ring. The slurry was kept } \\
\text { warm by recirculating through the heated } \\
\text { coils. }\end{array}$ & & & & & \\
\hline Sun, $2 / 2$ & $\begin{array}{l}\text { ANH-2: Same as } \\
\text { ANH-1 but with a } \\
\text { lower ART feed } \\
\text { rate. Avg. ART } \\
\text { conditions: } \\
\text { baseline } \\
\text { temperature, } 29 \\
\text { wt } \% \text { solids, } 1.1 \mathrm{M} \\
\mathrm{Na} \text {, baseline } \mathrm{pH}\end{array}$ & $\begin{array}{l}\text { The ART was emptied, and the sparge } \\
\text { ring was inspected. It was about } 40 \% \\
\text { plugged with solids. Once cleaned, the } \\
\text { ART was refilled to about } 3.7 \mathrm{~m}(12 \mathrm{ft}) \\
\text { with the previously transferred slurry. } \\
\text { The temperature was } 19^{\circ} \mathrm{C}\left(35^{\circ} \mathrm{F}\right) \text { below } \\
\text { baseline. Slurry from the FGDRT was } \\
\text { fed to the ART at } 0.06 \mathrm{~L} / \mathrm{s} \text { ( } 1 \mathrm{gpm}) \text {, and } \\
\text { the oxidation air rate was set at } 45 \\
\mathrm{Nm} 3 / \mathrm{h} \text { ( } 30 \text { scfm) to maintain a pH of } 0.2 \\
\text { pH units above baseline pH. These } \\
\text { conditions were consistent with previous } \\
\text { conditions before the sparged ring } \\
\text { plugged. }\end{array}$ & & & & & \\
\hline
\end{tabular}


Table B-1. Anhydrite Operations and Results Summary

\begin{tabular}{|c|c|c|c|c|c|c|c|}
\hline Date & $\begin{array}{c}\text { Test ID/ } \\
\text { Description }\end{array}$ & Operating/Results Summary & $\begin{array}{c}\text { Sample } \\
\text { ID }^{1}\end{array}$ & $\begin{array}{c}\text { Solid } \\
\text { Wt \% } \\
\text { Hydrate }\end{array}$ & $\begin{array}{c}\text { Est. } \\
\text { Wt \% } \\
\text { Anhydrite }\end{array}$ & $\begin{array}{c}\text { SEM } \\
\text { Description }\end{array}$ & $\begin{array}{c}\text { XRD } \\
\text { Description }\end{array}$ \\
\hline Mon, 2/3 & $\begin{array}{l}\text { ANH-2: Avg. ART } \\
\text { conditions: } \\
\text { baseline } \\
\text { temperature, } 29 \\
\text { wt } \% \text { solids, } 1.1 \mathrm{M} \\
\mathrm{Na} \text {, baseline } \mathrm{pH}\end{array}$ & $\begin{array}{l}\text { The ART temperature was slightly above } \\
\text { baseline by mid-afternoon. A tank fitting } \\
\text { failed, and about } 0.61 \mathrm{~m}(2 \mathrm{ft}) \text {. of slurry } \\
\text { was lost. ART feed rate was increased } \\
\text { to } 0.095 \mathrm{~L} / \mathrm{s}(1.5 \mathrm{gpm}) \text { and the oxidation } \\
\text { air rate to } 90 \mathrm{Nm} 3 / \mathrm{h}(60 \mathrm{scfm}) \text { to build } \\
\text { solids more quickly. }\end{array}$ & $\begin{array}{c}\mathrm{T}-121 \\
\mathrm{~T}-125\end{array}$ & $\begin{array}{l}20.4 \\
20.2\end{array}$ & $\begin{array}{l}0 \\
1\end{array}$ & $\begin{array}{l}\text { Normal } \\
\text { gypsum } \\
\text { crystals. } \\
\text { Mostly on } \\
\text { the order of } \\
100 \mu \mathrm{m} \text { in } \\
\text { length. }\end{array}$ & $\begin{array}{l}100 \% \\
\text { gypsum }\end{array}$ \\
\hline Tue,2/4 & $\begin{array}{l}\text { ANH-2: Avg. ART } \\
\text { conditions: } \\
\text { baseline } \\
\text { temperature, } 29 \\
\text { wt } \% \text { solids, } 1.1 \mathrm{M} \\
\mathrm{Na} \text {, baseline } \mathrm{pH}\end{array}$ & $\begin{array}{l}\text { More insulation was added to the ART. } \\
\text { The temperature increased from } 1 \text { to } 2^{\circ} \mathrm{C} \\
\left(2-4^{\circ} \mathrm{F}\right) \text { above baseline. Morning } \\
\text { samples indicated } 33 \% \text { anhydrite. A mid- } \\
\text { afternoon sample indicated } 67 \% \\
\text { anhydrite and an early evening sample } \\
76 \% \text {. Conditions throughout this time } \\
\text { consisted of a feed rate of } 0.095 \mathrm{~L} / \mathrm{s}(1.5 \\
\mathrm{gpm}) \text {, oxidation air rate of } 90 \mathrm{Nm} 3 / \mathrm{h}(60 \\
\text { scfm), and blowdown to the centrifuge. }\end{array}$ & $\begin{array}{l}\mathrm{T}-127 \\
\mathrm{~T}-131\end{array}$ & $\begin{array}{c}13.8 \\
6.8\end{array}$ & $\begin{array}{l}33 \\
67\end{array}$ & $\begin{array}{l}\text { Similar to } \\
\text { gypsum but } \\
\text { long and } \\
\text { skinny. } \\
\text { Rounded } \\
\text { edges. } \\
\text { Many } 100 \\
\mu m \text { long but } \\
\text { only few } \\
\mu \mathrm{m} \text { thick. } \\
\end{array}$ & $\begin{array}{l}\text { Gypsum, } \\
\text { hemihydrat } \\
\text { e, anhydrite } \\
\text { all present. } \\
\text { Based on } \\
\text { peak size, } \\
\text { hemi = } \\
\text { gypsum > } \\
\text { anhydrite. }\end{array}$ \\
\hline Wed, 2/5 & $\begin{array}{l}\text { ANH-2: Avg. ART } \\
\text { conditions: } \\
\text { baseline } \\
\text { temperature, } 29 \\
\text { wt } \% \text { solids, } 1.1 \mathrm{M} \\
\mathrm{Na} \text {, baseline } \mathrm{pH}\end{array}$ & $\begin{array}{l}\text { Morning and afternoon samples } \\
\text { indicated } 92 \% \text { anhydrite. The vacuum } \\
\text { belt was used with a warm water wash. }\end{array}$ & $\begin{array}{l}T-133 \\
T-138\end{array}$ & $\begin{array}{l}1.7 \\
2.0\end{array}$ & $\begin{array}{l}92 \\
90\end{array}$ & $\begin{array}{l}\text { Similar to } \\
\text { T-131. } \\
\text { Rounded } \\
\text { edges. } \\
\text { Many } 100 \\
\mu \mathrm{m} \text { long but } \\
\text { only few } \\
\mu \mathrm{m} \text { thick. } \\
\text { Some } \\
\text { growth out } \\
\text { of existing } \\
\text { crystals } \\
\text { starting. } \\
\end{array}$ & $\begin{array}{l}\text { Primarily } \\
\text { hemihydrat } \\
\text { e and } \\
\text { anhydrite. } \\
\text { Only small } \\
\text { gypsum } \\
\text { peak. }\end{array}$ \\
\hline Thu, 2/6 & $\begin{array}{l}\text { ANH-2: Avg. ART } \\
\text { conditions: } \\
\text { baseline } \\
\text { temperature, } 29 \\
\text { wt } \% \text { solids, } 1.1 \mathrm{M} \\
\mathrm{Na} \text {, baseline } \mathrm{pH}\end{array}$ & $\begin{array}{l}\text { The temperature has remained at } 3^{\circ} \mathrm{C} \\
\left(5^{\circ} \mathrm{F}\right) \text { above baseline. Morning samples } \\
\text { indicated } 98 \% \text { anhydrite while the } \\
\text { afternoon sample indicated } 93 \% \text {. }\end{array}$ & $\begin{array}{l}\mathrm{T}-141 \\
\mathrm{~T}-145\end{array}$ & $\begin{array}{l}0.4 \\
1.3\end{array}$ & $\begin{array}{l}98 \\
93\end{array}$ & $\begin{array}{l}\text { Similar to } \\
\text { T-133. } \\
\text { Crystals } \\
\text { getting } \\
\text { thicker but } \\
\text { still long. } \\
\text { Growth out } \\
\text { of existing } \\
\text { crystals } \\
\text { more } \\
\text { noticeable } \\
\text { (stars). }\end{array}$ & $\begin{array}{l}\text { No } \\
\text { gypsum. } \\
\text { Combinatio } \\
\mathrm{n} \text { of hemi } \\
\text { and } \\
\text { anhydrite. }\end{array}$ \\
\hline Fri, $2 / 7$ & $\begin{array}{l}\text { ANH-2: Avg. ART } \\
\text { conditions: } \\
\text { baseline } \\
\text { temperature, } 29 \\
\text { wt } \% \text { solids, } 1.1 \mathrm{M} \\
\mathrm{Na} \text {, baseline } \mathrm{pH}\end{array}$ & $\begin{array}{l}\text { Took last set of final samples at the } \\
\text { following conditions: } \mathrm{O}: \mathrm{SO}_{2} \text { ratio } 2.3 \text {, } \\
\text { Solid residence time } 98 \mathrm{hrs} \text {. ( } 29 \mathrm{wt} \%) \text {, } \\
\text { pH near baseline, } 1^{\circ} \mathrm{C}\left(2^{\circ} \mathrm{F}\right) \text { below } \\
\text { baseline. Test conditions were then } \\
\text { changed by increasing the pH by } 0.6 \\
\text { units by reducing the oxidation air rate. } \\
\text { The FGDRT solids concentration } \\
\text { decreased from } 29 \% \text { to } 21 \% \text {. }\end{array}$ & $\begin{array}{l}\mathrm{T}-147 \\
\mathrm{~T}-152\end{array}$ & $\begin{array}{l}1.6 \\
1.6\end{array}$ & $\begin{array}{l}92 \\
92\end{array}$ & $\begin{array}{l}\text { Same as } \\
\text { T141 }\end{array}$ & No sample. \\
\hline
\end{tabular}

B-6 
Table B-1. Anhydrite Operations and Results Summary

\begin{tabular}{|c|c|c|c|c|c|c|c|}
\hline Date & $\begin{array}{c}\text { Test ID/ } \\
\text { Description }\end{array}$ & Operating/Results Summary & $\begin{array}{c}\text { Sample } \\
\text { ID }^{1}\end{array}$ & $\begin{array}{c}\text { Solid } \\
\text { Wt \% } \\
\text { Hydrate }\end{array}$ & $\begin{array}{c}\text { Est. } \\
\text { Wt \% } \\
\text { Anhydrite }\end{array}$ & $\begin{array}{c}\text { SEM } \\
\text { Description }\end{array}$ & $\begin{array}{c}\text { XRD } \\
\text { Description }\end{array}$ \\
\hline Sat, 2/8 & $\begin{array}{l}\text { ANH-3: Same as } \\
\text { ANH-2 with higher } \\
\mathrm{pH} \text { and lower ox. } \\
\text { air rate. Avg. ART } \\
\text { conditions: } \\
\text { baseline } \\
\text { temperature, } 23 \\
\text { wt \% solids, } 1.2 \mathrm{M} \\
\mathrm{Na}, 0.4 \text { units } \\
\text { above baseline } \\
\text { pH. }\end{array}$ & $\begin{array}{l}\text { The anhydrite concentration had } \\
\text { decreased to } 78 \% \text { by the morning } \\
\text { sample and to } 67 \% \text { by afternoon. The } \\
\text { oxidation air rate had only been reduced } \\
\text { from } 90 \mathrm{Nm} 3 / \mathrm{h}(60 \mathrm{scfm}) \text { to } 83 \mathrm{Nm} 3 / \mathrm{h} \\
\text { ( } 55 \mathrm{scfm} \text { ) to maintain a pH of } 0.6 \text { units } \\
\text { above baseline. }\end{array}$ & $\begin{array}{l}\mathrm{T}-157 \\
\mathrm{~T}-158\end{array}$ & $\begin{array}{l}4.5 \\
6.8\end{array}$ & $\begin{array}{l}78 \\
67\end{array}$ & $\begin{array}{l}\text { Same as T- } \\
141 \text { but } \\
\text { with less } \\
\text { growth from } \\
\text { existing } \\
\text { crystals } \\
\text { (fewer } \\
\text { stars). }\end{array}$ & No sample. \\
\hline Mon, 2/10 & $\begin{array}{l}\text { ANH-3: Avg. ART } \\
\text { conditions: } \\
\text { baseline } \\
\text { temperature, } 23 \\
\text { wt \% solids, } 1.2 \mathrm{M} \\
\mathrm{Na}, 0.4 \text { units } \\
\text { above baseline } \\
\mathrm{pH} \text {. }\end{array}$ & $\begin{array}{l}\text { Morning samples indicated } 67 \% \\
\text { anhydrite and afternoon samples } 61 \% \text {. } \\
\text { Conditions included an } \mathrm{O}: \mathrm{SO}_{2} \text { ratio of } \\
2.3 \text {, solid residence time of } 85 \mathrm{hrs} ., \mathrm{pH} \\
0.6 \text { units above baseline, and } \\
\text { temperature of } 2^{\circ} \mathrm{C}\left(4^{\circ} \mathrm{F}\right) \text { above } \\
\text { baseline. }\end{array}$ & $\begin{array}{l}\mathrm{T}-154 \\
\mathrm{~T}-160\end{array}$ & $\begin{array}{l}6.9 \\
7.9\end{array}$ & $\begin{array}{l}67 \\
61\end{array}$ & $\begin{array}{l}\text { Same as T- } \\
157 .\end{array}$ & $\begin{array}{l}\text { Gypsum, } \\
\text { hemihydrat } \\
\text { e, anhydrite } \\
\text { all present. } \\
\text { Based on } \\
\text { peak size, } \\
\text { hemi = } \\
\text { gypsum > } \\
\text { anhydrite. } \\
\end{array}$ \\
\hline Tue, 2/11 & $\begin{array}{l}\text { ANH-3: Avg. ART } \\
\text { conditions: } \\
\text { baseline } \\
\text { temperature, } 23 \\
\text { wt } \% \text { solids, } 1.2 \mathrm{M} \\
\mathrm{Na}, 0.4 \text { units } \\
\text { above baseline } \\
\mathrm{pH}\end{array}$ & $\begin{array}{l}\text { The ART temperature dropped slightly } \\
\text { during the early morning to near baseline } \\
\text { due to a low water temperature. The } \\
\text { temperature increased to } 2^{\circ} \mathrm{C}\left(4^{\circ} \mathrm{F}\right) \\
\text { above baseline throughout the day. } \\
\text { Morning and afternoon samples } \\
\text { indicated about } 45 \% \text { anhydrite. The } \mathrm{pH} \\
\text { was decreased to baseline by increasing } \\
\text { the oxidation air rate from } 69 \mathrm{Nm}^{3} / \mathrm{h}(46 \\
\left.\text { scfm) to } 78 \mathrm{Nm}^{3} / \mathrm{h} \text { ( } 52 \mathrm{scfm}\right) \text {. Blowdown } \\
\text { was switched to the centrifuge, but the } \\
\text { centrifuge soon failed. The vacuum belt } \\
\text { was then used again. }\end{array}$ & $\begin{array}{l}\mathrm{T}-162 \\
\mathrm{~T}-166\end{array}$ & $\begin{array}{l}10.6 \\
11.3\end{array}$ & $\begin{array}{l}48 \\
45\end{array}$ & & \\
\hline Wed, 2/12 & $\begin{array}{l}\text { ANH-4: Same as } \\
\text { ANH-2. Avg. ART } \\
\text { conditions: } \\
\text { baseline } \\
\text { temperature, } 25 \\
\text { wt \% solids, } 1.2 \mathrm{M} \\
\mathrm{Na} \text {, baseline } \mathrm{pH} \text {. }\end{array}$ & $\begin{array}{l}\text { The ART temperature was } 2^{\circ} \mathrm{C}\left(4^{\circ} \mathrm{F}\right) \\
\text { above baseline. Morning samples } \\
\text { indicated } 45 \% \text { anhydrite while afternoon } \\
\text { samples indicated } 56 \% \text {. Since the } \\
\text { anhydrite concentration appeared to be } \\
\text { increasing, conditions were maintained. }\end{array}$ & $\begin{array}{l}\mathrm{T}-168 \\
\mathrm{~T}-173\end{array}$ & $\begin{array}{c}11.2 \\
9.0\end{array}$ & $\begin{array}{l}45 \\
56\end{array}$ & $\begin{array}{l}\text { Same as T- } \\
157 . \\
\text { Crystals } \\
\text { are starting } \\
\text { to get } \\
\text { thicker } \\
\text { (lower } \\
\text { aspect } \\
\text { ratio). }\end{array}$ & No sample. \\
\hline Thu, 2/13 & $\begin{array}{l}\text { ANH-4: Avg. ART } \\
\text { conditions: } \\
\text { baseline } \\
\text { temperature, } 25 \\
\text { wt } \% \text { solids, } 1.2 \mathrm{M} \\
\mathrm{Na} \text {, baseline } \mathrm{pH}\end{array}$ & $\begin{array}{l}\text { Morning samples indicated } 68 \% \\
\text { anhydrite while afternoon samples } \\
\text { indicated } 70 \% \text {. The anhydrite } \\
\text { concentration appears to be stabilizing. }\end{array}$ & $\begin{array}{l}\mathrm{T}-175 \\
\mathrm{~T}-179\end{array}$ & $\begin{array}{l}6.6 \\
6.1\end{array}$ & $\begin{array}{l}68 \\
70\end{array}$ & $\begin{array}{l}\text { Looks like } \\
\text { T-157 but } \\
\text { the crystals } \\
\text { are thicker } \\
\text { and growth } \\
\text { on existing } \\
\text { crystals is } \\
\text { more } \\
\text { noticeable. }\end{array}$ & No sample. \\
\hline Fri, 2/14 & $\begin{array}{l}\text { ANH-4: Avg. ART } \\
\text { conditions: } \\
\text { baseline } \\
\text { temperature, } 25 \\
\text { wt \% solids, } 1.2 \mathrm{M} \\
\mathrm{Na} \text {, baseline } \mathrm{pH}\end{array}$ & $\begin{array}{l}\text { Morning samples indicated about the } \\
\text { same level of anhydrite. The } \mathrm{pH} \text { was } \\
\text { decreased by } 0.3 \mathrm{pH} \text { units below } \\
\text { baseline to determine if lower } \mathrm{pH} \text { helped } \\
\text { with the formation of anhydrite. }\end{array}$ & $\begin{array}{l}\mathrm{T}-181 \\
\mathrm{~T}-185\end{array}$ & $\begin{array}{l}6.6 \\
6.5\end{array}$ & $\begin{array}{l}68 \\
68\end{array}$ & $\begin{array}{l}\text { Same as T- } \\
175 .\end{array}$ & No sample. \\
\hline
\end{tabular}


Table B-1. Anhydrite Operations and Results Summary

\begin{tabular}{|c|c|c|c|c|c|c|c|}
\hline Date & $\begin{array}{c}\text { Test ID/ } \\
\text { Description }\end{array}$ & Operating/Results Summary & $\begin{array}{c}\text { Sample } \\
\text { ID }^{1}\end{array}$ & $\begin{array}{c}\text { Solid } \\
\text { Wt \% } \\
\text { Hydrate }\end{array}$ & $\begin{array}{c}\text { Est. } \\
\text { Wt \% } \\
\text { Anhydrite }\end{array}$ & $\begin{array}{c}\text { SEM } \\
\text { Description }\end{array}$ & $\begin{array}{c}\text { XRD } \\
\text { Description } \\
\end{array}$ \\
\hline Sat, $2 / 15$ & $\begin{array}{l}\text { ANH-5: Same as } \\
\text { ANH-4 with } 0.3 \\
\text { units below } \\
\text { baseline } \mathrm{pH} \text {. }\end{array}$ & $\begin{array}{l}\text { The } \mathrm{pH} \text { had no effect. The hydrocyclone } \\
\text { was tested to concentrate anhydrite. } \\
\text { With limited samples, there was no } \\
\text { detectable separation of anhydrite } \\
\text { between underflow and overflow. ART } \\
\text { slurry was recirculated through a } \\
\text { centrifugal pump in an attempt to make } \\
\text { the anhydrite crystals smaller. }\end{array}$ & - & 7.8 & 63 & No sample. & No sample. \\
\hline Mon, 2/17 & $\begin{array}{l}\text { ANH-6: Trying to } \\
\text { repeat ANH-2 but } \\
\text { had difficulty } \\
\text { achieving pH and } \\
\text { solid wt \%. }\end{array}$ & $\begin{array}{l}\text { Morning samples indicated about } 45 \% \\
\text { anhydrite, and the crystals did not } \\
\text { appear to be broken by the centrifugal } \\
\text { pump (under the microscope). The ART } \\
\text { solids concentration had dropped to } 18 \\
\text { wt } \% \text {. Also, the liquid sulfite } \\
\text { concentration was low. After fixing some } \\
\text { pH tree problems, the ART pH was very } \\
\text { high. Increasing the oxidation air rate to } \\
150 \mathrm{Nm}^{3} / \mathrm{h} \text { (100 scfm) did not lower the } \\
\mathrm{pH} \text { so additive } 1 \text { was added to achieve } \\
\text { baseline pH. Eventually, a pH of } 0.2 \\
\text { units above baseline was obtained with } \\
120 \mathrm{Nm}^{3} / \mathrm{h} \text { ( } 80 \mathrm{scfm} \text { ) of air. The FGDRT } \\
\mathrm{pH} \text { is also high at } 6.4 \text {. }\end{array}$ & $\begin{array}{l}\text { T-187 } \\
\text { T-194 }\end{array}$ & $\begin{array}{l}11.9 \\
11.0\end{array}$ & $\begin{array}{l}42 \\
46\end{array}$ & $\begin{array}{l}\text { Crystals } \\
\text { are thicker } \\
\text { but still } \\
\text { long. Not } \\
\text { much } \\
\text { growth on } \\
\text { existing } \\
\text { crystals. }\end{array}$ & $\begin{array}{l}\text { Gypsum, } \\
\text { hemihydrat } \\
\text { e, anhydrite } \\
\text { all present. } \\
\text { Based on } \\
\text { peak size, } \\
\text { gypsum > } \\
\text { hemi = } \\
\text { anhydrite. }\end{array}$ \\
\hline Tue, 2/18 & $\begin{array}{l}\text { ANH-6: Trying to } \\
\text { repeat ANH-2 but } \\
\text { had difficulty } \\
\text { achieving pH and } \\
\text { solid wt \%. }\end{array}$ & $\begin{array}{l}\text { Oxidation air rate was dropped to } 60 \\
\mathrm{Nm} 3 / \mathrm{h}(40 \mathrm{scfm}) \text { to keep } \mathrm{pH} \text { up. Liquid } \\
\text { sulfite was higher. Conditions were } \\
\text { similar to ANH-2 but anhydrite content } \\
\text { was low. Added } \mathrm{Na} \text { at } 17: 00 \text {. ART solids } \\
\text { being removed on level control to } \\
\text { prevent line pluggage by maintaining } \\
0.13 \mathrm{~L} / \mathrm{s} \text { ( } 2 \mathrm{gpm}) \text { flow rate. }\end{array}$ & $\begin{array}{l}\text { T-196 } \\
\text { T-200 }\end{array}$ & $\begin{array}{l}16.6 \\
14.8\end{array}$ & $\begin{array}{l}19 \\
28\end{array}$ & $\begin{array}{l}\text { Big, blocky } \\
\text { crystals } \\
\text { present } \\
\text { (probably } \\
\text { gypsum). } \\
\text { Some of } \\
\text { the higher } \\
\text { aspect ratio } \\
\text { crystals. }\end{array}$ & $\begin{array}{l}\text { Gypsum, } \\
\text { hemihydrat } \\
\text { e, anhydrite } \\
\text { all present. } \\
\text { Based on } \\
\text { peak size, } \\
\text { gypsum >> } \\
\text { hemi = } \\
\text { anhydrite. } \\
\end{array}$ \\
\hline Wed, 2/19 & $\begin{array}{l}\text { ANH-7: Try to } \\
\text { increase } \mathrm{Na} \text {. }\end{array}$ & $\begin{array}{l}\text { The Na conc. had increased only slightly } \\
\text { but the SO3 conc. had increased. At } \\
14: 00 \text {, mechanism A1 was used for } \\
\text { surface area control. }\end{array}$ & $\begin{array}{l}\text { T-202 } \\
\text { T-206 } \\
\text { T-211 }\end{array}$ & $\begin{array}{c}12.6 \\
11.2 \\
9.2\end{array}$ & $\begin{array}{l}39 \\
45 \\
55\end{array}$ & $\begin{array}{l}\text { Mixture of } \\
\text { big gypsum } \\
\text { and high } \\
\text { aspect ratio } \\
\text { crystals. }\end{array}$ & $\begin{array}{l}\text { Gypsum, } \\
\text { hemihydrat } \\
\text { e, anhydrite } \\
\text { all present. } \\
\text { Based on } \\
\text { peak size, } \\
\text { gypsum }>> \\
\text { hemi = } \\
\text { anhydrite. } \\
\end{array}$ \\
\hline Thu, 2/20 & $\begin{array}{l}\text { ANH-8: Using } \\
\text { mechanism A2 for } \\
\text { surface area } \\
\text { control. Avg. ART } \\
\text { conditions: } \\
\text { baseline } \\
\text { temperature, } 22 \\
\text { wt \% solids, } 1.2 \mathrm{M} \\
\mathrm{Na} \text {, baseline pH }\end{array}$ & $\begin{array}{l}\text { Using mechanism } \mathrm{A} 2 \text { for surface area } \\
\text { control. Anhydrite content increased. } \\
\text { Centrifuge used for dewatering with } \\
\text { batch feed. Lime injected at SDA to } \\
\text { achieve } 107^{\circ} \mathrm{C}\left(225^{\circ} \mathrm{F}\right) \text { outlet and } 10 \\
\text { molar ratio. } \mathrm{HCl} \text { dropped from } 44 \mathrm{ppm} \text { to } \\
\text { about } 6 \mathrm{ppm} \text {. }\end{array}$ & $\begin{array}{l}\text { T-208 } \\
\text { T-213 }\end{array}$ & $\begin{array}{l}4.7 \\
4.6\end{array}$ & $\begin{array}{l}77 \\
78\end{array}$ & $\begin{array}{l}\text { Big gypsum } \\
\text { is gone. } \\
\text { Mainly } \\
\text { long, round- } \\
\text { edge } \\
\text { crystals } \\
\text { that are } \\
\text { thicker than } \\
\text { previous } \\
\text { ones. }\end{array}$ & $\begin{array}{l}\text { Gypsum, } \\
\text { hemihydrat } \\
\text { e, anhydrite } \\
\text { all present. } \\
\text { Based on } \\
\text { peak size, } \\
\text { hemi = } \\
\text { anhydrite } \\
\text { >> gypsum. }\end{array}$ \\
\hline
\end{tabular}


Table B-1. Anhydrite Operations and Results Summary

\begin{tabular}{|c|c|c|c|c|c|c|c|}
\hline Date & $\begin{array}{c}\text { Test ID/ } \\
\text { Description }\end{array}$ & Operating/Results Summary & $\begin{array}{l}\text { Sample } \\
\text { ID }^{1}\end{array}$ & $\begin{array}{c}\text { Solid } \\
\text { Wt \% } \\
\text { Hydrate }\end{array}$ & $\begin{array}{c}\text { Est. } \\
\text { Wt \% } \\
\text { Anhydrite }\end{array}$ & $\begin{array}{c}\text { SEM } \\
\text { Description }\end{array}$ & $\begin{array}{c}\text { XRD } \\
\text { Description }\end{array}$ \\
\hline Fri, 2/21 & $\begin{array}{l}\text { ANH-8: Using } \\
\text { mechanism A2 for } \\
\text { surface area } \\
\text { control. Avg. ART } \\
\text { conditions: } \\
\text { baseline } \\
\text { temperature, } 22 \\
\text { wt \% solids, } 1.2 \mathrm{M} \\
\mathrm{Na} \text {, baseline } \mathrm{pH}\end{array}$ & $\begin{array}{l}\text { Continuing to use mechanism } \mathrm{A} 2 \text { for } \\
\text { surface area control and producing } \\
\text { anhydrite. Lime to SDA stopped. }\end{array}$ & $\begin{array}{l}\text { T-215 } \\
\text { T-219 }\end{array}$ & $\begin{array}{l}2.1 \\
1.9\end{array}$ & $\begin{array}{l}90 \\
91\end{array}$ & No sample. & $\begin{array}{l}\text { Very little } \\
\text { gypsum. } \\
\text { Looks like } \\
\text { equal } \\
\text { amounts of } \\
\text { hemihydrat } \\
\text { e and } \\
\text { anhydrite. }\end{array}$ \\
\hline $\begin{array}{l}\text { Sat-Sun, } \\
2 / 22-2 / 23\end{array}$ & $\mathrm{ANH}-8$ & $\begin{array}{l}\text { No problems. Continuing to use } \\
\text { mechanism A2 for surface area control. }\end{array}$ & & & & & \\
\hline Mon, 2/24 & $\begin{array}{l}\text { ANH-8: Using } \\
\text { mechanism A2 for } \\
\text { surface area } \\
\text { control. Avg. ART } \\
\text { conditions: } \\
\text { baseline } \\
\text { temperature, } 22 \\
\text { wt \% solids, } 1.2 \mathrm{M} \\
\mathrm{Na} \text {, baseline } \mathrm{pH}\end{array}$ & Centrifuge product was collected. & $\begin{array}{l}\text { T-221 } \\
\text { T-225 }\end{array}$ & $\begin{array}{l}1.7 \\
1.8\end{array}$ & $\begin{array}{l}92 \\
91\end{array}$ & $\begin{array}{l}\text { High aspect } \\
\text { ratio } \\
\text { crystals } \\
\text { with a lot of } \\
\text { fines. } \\
\text { Starting } \\
\text { bow ties. }\end{array}$ & $\begin{array}{l}\text { No } \\
\text { gypsum. } \\
\text { Looks like } \\
\text { slightly } \\
\text { more } \\
\text { anhydrite } \\
\text { than hemi. }\end{array}$ \\
\hline Tue, 2/25 & $\begin{array}{l}\text { ANH-8: Using } \\
\text { mechanism A2. } \\
\text { Avg. ART } \\
\text { conditions: } \\
\text { baseline } \\
\text { temperature, } 22 \\
\text { wt \% solids, } 1.2 \mathrm{M} \\
\mathrm{Na} \text {, baseline } \mathrm{pH}\end{array}$ & $\begin{array}{l}\text { Five barrels of centrifuge product were } \\
\text { collected overnight. Started collecting } \\
\text { one bucket per day. Lime to SDA froze } \\
\text { and had to be thawed. }\end{array}$ & $\begin{array}{l}\text { T-227 } \\
\text { T-331 }\end{array}$ & $\begin{array}{l}0.8 \\
0.5\end{array}$ & $\begin{array}{l}96 \\
98\end{array}$ & No sample. & $\begin{array}{l}\text { No } \\
\text { gypsum. } \\
\text { Some hemi } \\
\text { but } \\
\text { anhydrite } \\
\text { peak is } \\
\text { bigger. }\end{array}$ \\
\hline Wed, 2/26 & $\begin{array}{l}\text { ANH-8: Using } \\
\text { mechanism A2 for } \\
\text { surface area } \\
\text { control. Avg. ART } \\
\text { conditions: } \\
\text { baseline } \\
\text { temperature, } 22 \\
\text { wt \% solids, } 1.2 \mathrm{M} \\
\mathrm{Na} \text {, baseline } \mathrm{pH}\end{array}$ & $\begin{array}{l}\text { Collected last set of final samples. } \\
\text { Lowered } \mathrm{pH} \text { to } 0.3 \mathrm{pH} \text { units below } \\
\text { baseline using oxidation air. The lime } \\
\text { test at } 5 \text { molar ratio resulted in } 18 \mathrm{ppm} \\
\mathrm{HCl} \text {. The ratio was dropped to } 2 \text {. }\end{array}$ & $\begin{array}{l}\text { T-233 } \\
\text { T-237 }\end{array}$ & $\begin{array}{l}0.7 \\
0.6\end{array}$ & $\begin{array}{l}96 \\
97\end{array}$ & & \\
\hline Thu, 2/27 & $\begin{array}{l}\text { ANH-9: Same as } \\
\text { ANH-8 but pH } 0.4 \\
\text { units below } \\
\text { baseline. }\end{array}$ & $\begin{array}{l}\mathrm{pH} \text { appeared to have no effect. At } 10: 00 \text {, } \\
\text { stopped adding soda ash to decrease } \\
\mathrm{Na} \text { and increased } \mathrm{pH} \text { to baseline. } 28 \\
\text { ppm } \mathrm{HCl} \text { achieved at } 2 \text { molar ratio. Ratio } \\
\text { increased to } 10 \text { and temperature } \\
\text { decreased to } 93^{\circ} \mathrm{C}\left(200^{\circ} \mathrm{F}\right) \text {. }\end{array}$ & $\begin{array}{l}\text { T-240 } \\
\text { T-244 }\end{array}$ & $\begin{array}{l}0.6 \\
0.6\end{array}$ & $\begin{array}{l}97 \\
97\end{array}$ & $\begin{array}{l}\text { Mainly } \\
\text { fines. } \\
\text { Relatively } \\
\text { few long, } \\
\text { thin } \\
\text { crystals. } \\
\text { Crystals } \\
\text { look more } \\
\text { like stacked } \\
\text { platelets. }\end{array}$ & $\begin{array}{l}\text { No } \\
\text { gypsum. } \\
\text { Hemi peak } \\
\text { getting } \\
\text { smaller with } \\
\text { anhydrite } \\
\text { peak } \\
\text { getting } \\
\text { bigger. }\end{array}$ \\
\hline
\end{tabular}


Table B-1. Anhydrite Operations and Results Summary

\begin{tabular}{|c|c|c|c|c|c|c|c|}
\hline Date & $\begin{array}{l}\text { Test ID/ } \\
\text { Description }\end{array}$ & Operating/Results Summary & $\begin{array}{l}\text { Sample } \\
\text { ID }^{1}\end{array}$ & $\begin{array}{c}\text { Solid } \\
\text { Wt \% } \\
\text { Hydrate }\end{array}$ & $\begin{array}{c}\text { Est. } \\
\text { Wt \% } \\
\text { Anhydrite }\end{array}$ & $\begin{array}{c}\text { SEM } \\
\text { Description }\end{array}$ & $\begin{array}{c}\text { XRD } \\
\text { Description }\end{array}$ \\
\hline Fri, $2 / 28$ & $\begin{array}{l}\text { ANH-10: Same as } \\
\text { ANH-8 with no } \\
\text { soda ash addition. } \\
\text { Avg. ART } \\
\text { conditions: } 2^{\circ} \mathrm{C} \\
\left.\text { ( } 4^{\circ} \mathrm{F}\right) \text { below } \\
\text { baseline temp., } \\
19 \text { wt } \% \text { solids, } \\
1.1 \mathrm{M} \mathrm{Na} \text {, } \\
\text { baseline } \mathrm{pH} \text {. }\end{array}$ & $\begin{array}{l}\text { The ART temperature dropped from } 2 \text { to } \\
4^{\circ} \mathrm{C}\left(3-6^{\circ} \mathrm{F}\right) \text { above baseline temperature. } \\
\text { This decrease is attributed to increased } \\
\text { water addition with the oxidation air. The } \\
\text { air water rate was reduced. SDA was } \\
\text { removed from the gas path. Started third } \\
\text { spray header to build FGDRT solids. }\end{array}$ & $\begin{array}{l}\mathrm{T}-246 \\
\mathrm{~T}-252\end{array}$ & $\begin{array}{l}2.7 \\
2.5\end{array}$ & $\begin{array}{l}87 \\
88\end{array}$ & $\begin{array}{l}\text { Mainly } \\
\text { fines. } \\
\text { Relatively } \\
\text { few long, } \\
\text { thin } \\
\text { crystals. } \\
\text { Small, } \\
\text { blocking } \\
\text { growth off } \\
\text { of existing } \\
\text { crystals. } \\
\end{array}$ & $\begin{array}{l}\text { A little } \\
\text { gypsum } \\
\text { and hemi. } \\
\text { Mainly } \\
\text { anhydrite. }\end{array}$ \\
\hline Sat, 3/1 & $\mathrm{ANH}-10$ & $\begin{array}{l}\text { Temperature back to } 3^{\circ} \mathrm{C}\left(5^{\circ} \mathrm{F}\right) \text { above } \\
\text { baseline temperature. }\end{array}$ & & & & & \\
\hline Sun, $3 / 2$ & ANH-10 & $\begin{array}{l}\text { The third header was shutdown. The } \\
\text { centrifuge product looked wetter and } \\
\text { was extremely hard after entering the } \\
\text { dumpster. Solids were difficult to break. }\end{array}$ & & & & & \\
\hline Mon, 3/3 & $\begin{array}{l}\text { ANH-10: Using } \\
\text { mechanism A2. } \\
\text { Avg. ART } \\
\text { conditions: } 2^{\circ} \mathrm{C} \\
\left(4^{\circ} \mathrm{F}\right) \text { below } \\
\text { baseline temp., } \\
19 \text { wt } \% \text { solids, } \\
1.1 \mathrm{M} \mathrm{Na} \\
\text { baseline } \mathrm{pH} \text {. }\end{array}$ & $\begin{array}{l}\text { Centrifuge product was different than } \\
\text { before. Increase in gypsum for unknown } \\
\text { reason. Despite stopping soda ash } \\
\text { addition, Na conc. remains high. }\end{array}$ & $\begin{array}{l}\text { T-254 } \\
\text { T-258 }\end{array}$ & $\begin{array}{l}4.6 \\
4.4\end{array}$ & $\begin{array}{l}78 \\
78\end{array}$ & $\begin{array}{l}\text { Fines with } \\
\text { a few } \\
\text { blocky } \\
\text { crystals } \\
\text { (probably } \\
\text { gypsum). }\end{array}$ & $\begin{array}{l}\text { No hemi. } \\
\text { Some } \\
\text { gypsum } \\
\text { with mainly } \\
\text { anhydrite. }\end{array}$ \\
\hline Tue, 3/4 & $\begin{array}{l}\text { ANH-10: Using } \\
\text { mechanism A2. } \\
\text { Avg. ART } \\
\text { conditions: } 2^{\circ} \mathrm{C} \\
\left(4^{\circ} \mathrm{F}\right) \text { below } \\
\text { baseline temp., } \\
19 \text { wt } \% \text { solids, } \\
1.1 \mathrm{M} \mathrm{Na} \text {, } \\
\text { baseline } \mathrm{pH} \text {. }\end{array}$ & $\begin{array}{l}\text { Took final samples. Began crushing } \\
\text { some of the centrifuge product. The } \\
\text { pieces first had to be broken with a } \\
\text { hammer. The solids were not completely } \\
\text { dry and caked the mill. The powder } \\
\text { being ground contained about } 13 \% \\
\text { hydrate. }\end{array}$ & $\begin{array}{l}\text { T-260 } \\
\text { T-264 }\end{array}$ & $\begin{array}{l}3.7 \\
4.4\end{array}$ & $\begin{array}{l}82 \\
79\end{array}$ & $\begin{array}{l}\text { Fines with } \\
\text { a few } \\
\text { blocky } \\
\text { crystals } \\
\text { (probably } \\
\text { gypsum). }\end{array}$ & $\begin{array}{l}\text { No hemi. } \\
\text { Some } \\
\text { gypsum } \\
\text { with mainly } \\
\text { anhydrite. }\end{array}$ \\
\hline Wed, $3 / 5$ & $\begin{array}{l}\text { ANH-10: Using } \\
\text { mechanism A2. } \\
\text { Avg. ART } \\
\text { conditions: } 2^{\circ} \mathrm{C} \\
\left(4^{\circ} \mathrm{F}\right) \text { below } \\
\text { baseline temp., } \\
19 \text { wt } \% \text { solids, } \\
1.1 \mathrm{M} \mathrm{Na} \\
\text { baseline } \mathrm{pH} .\end{array}$ & $\begin{array}{l}\text { Centrifuge product dried in air was hard } \\
\text { within about } 30 \text { minutes. Some product } \\
\text { was also collected in isopropanol for the } \\
\text { first time. Dried solids were mixed with } \\
\text { water and set up within about one hour. }\end{array}$ & $\begin{array}{l}\mathrm{T}-267 \\
\mathrm{~T}-271\end{array}$ & $\begin{array}{l}3.2 \\
3.5\end{array}$ & $\begin{array}{l}84 \\
83\end{array}$ & $\begin{array}{l}\text { Fines with } \\
\text { a few } \\
\text { blocky } \\
\text { crystals } \\
\text { (probably } \\
\text { gypsum). } \\
\text { Stacked } \\
\text { platelet } \\
\text { type } \\
\text { crystals } \\
\text { dominant. }\end{array}$ & $\begin{array}{l}\text { No hemi. } \\
\text { Some } \\
\text { gypsum } \\
\text { with mainly } \\
\text { anhydrite. }\end{array}$ \\
\hline
\end{tabular}


Table B-1. Anhydrite Operations and Results Summary

\begin{tabular}{|c|c|c|c|c|c|c|c|}
\hline Date & $\begin{array}{c}\text { Test ID/ } \\
\text { Description }\end{array}$ & Operating/Results Summary & $\begin{array}{l}\text { Sample } \\
\text { ID }^{1}\end{array}$ & $\begin{array}{c}\text { Solid } \\
\text { Wt \% } \\
\text { Hydrate }\end{array}$ & $\begin{array}{c}\text { Est. } \\
\text { Wt \% } \\
\text { Anhydrite }\end{array}$ & $\begin{array}{c}\text { SEM } \\
\text { Description }\end{array}$ & $\begin{array}{c}\text { XRD } \\
\text { Description }\end{array}$ \\
\hline Thu, 3/6 & $\begin{array}{l}\text { ANH-10: Using } \\
\text { mechanism A2. } \\
\text { Avg. ART } \\
\text { conditions: } 2^{\circ} \mathrm{C} \\
\left(4^{\circ} \mathrm{F}\right) \text { below } \\
\text { baseline temp., } \\
19 \text { wt } \% \text { solids, } \\
1.1 \mathrm{M} \mathrm{Na} \text {, } \\
\text { baseline } \mathrm{pH} .\end{array}$ & $\begin{array}{l}\text { Continued operation with no } \mathrm{Na} \text { addition } \\
\text { and using mechanism A2 for surface } \\
\text { area control. Solids washed with acetone } \\
\text { and hot water on the filter resulted in the } \\
\text { same \% hydrate. The inlet SO2 was } \\
\text { increased and the third header started to } \\
\text { build solids for low-cost operation. }\end{array}$ & $\begin{array}{l}\text { T-273 } \\
\text { T-277 }\end{array}$ & $\begin{array}{l}3.7 \\
4.1\end{array}$ & $\begin{array}{l}82 \\
80\end{array}$ & $\begin{array}{l}\text { Fines with } \\
\text { a few } \\
\text { blocky } \\
\text { crystals } \\
\text { (probably } \\
\text { gypsum). } \\
\text { Stacked } \\
\text { platelet } \\
\text { type } \\
\text { crystals } \\
\text { dominant. }\end{array}$ & $\begin{array}{l}\text { No hemi. } \\
\text { Some } \\
\text { gypsum } \\
\text { with mainly } \\
\text { anhydrite. }\end{array}$ \\
\hline Fri, $3 / 7$ & $\begin{array}{l}\text { ANH-10: Using } \\
\text { mechanism A2. } \\
\text { Avg. ART } \\
\text { conditions: } 2^{\circ} \mathrm{C} \\
\left(4^{\circ} \mathrm{F}\right) \text { below } \\
\text { baseline temp., } \\
19 \mathrm{wt} \% \text { solids, } \\
1.1 \mathrm{M} \mathrm{Na} \text {, } \\
\text { baseline } \mathrm{pH} \text {. }\end{array}$ & $\begin{array}{l}\text { Na concentration dropped slightly. Soda } \\
\text { ash addition started again over the } \\
\text { weekend. Centrifuge solids were } \\
\text { collected in alcohol. The solids dumpster } \\
\text { empties as one large rock. Operated at } \\
\text { "weekend" conditions to build solids. }\end{array}$ & $\begin{array}{l}\mathrm{T}-279 \\
\mathrm{~T}-283\end{array}$ & $\begin{array}{l}2.8 \\
3.3\end{array}$ & $\begin{array}{l}86 \\
84\end{array}$ & $\begin{array}{l}\text { Fines with } \\
\text { a few } \\
\text { blocky } \\
\text { crystals } \\
\text { (probably } \\
\text { gypsum). } \\
\text { Stacked } \\
\text { platelet } \\
\text { type } \\
\text { crystals } \\
\text { dominant. }\end{array}$ & $\begin{array}{l}\text { No hemi. } \\
\text { Very little } \\
\text { gypsum } \\
\text { with mainly } \\
\text { anhydrite. }\end{array}$ \\
\hline Mon, 3/10 & $\begin{array}{l}\text { ANH-11: Same as } \\
\text { ANH-10 but low- } \\
\text { cost operation. } \\
\text { Avg. ART } \\
\text { conditions: } \\
\text { baseline } \\
\text { temperature, } 23 \\
\text { wt \% solids, } 1.1 \mathrm{M} \\
\mathrm{Na} \text {, baseline } \mathrm{pH}\end{array}$ & $\begin{array}{l}\text { The scrubber was taken offline in the } \\
\text { morning. The limestone was accidentally } \\
\text { left on and the pH increased to } 5.9 \text { in the } \\
\text { FGDRT. The centrifuge product } \\
\text { appeared drier but was not. }\end{array}$ & $\begin{array}{l}\mathrm{T}-285 \\
\mathrm{~T}-288\end{array}$ & $\begin{array}{l}3.6 \\
3.2\end{array}$ & $\begin{array}{l}83 \\
84\end{array}$ & $\begin{array}{l}\text { Mostly fines } \\
\text { with very } \\
\text { few blocky } \\
\text { crystals. }\end{array}$ & $\begin{array}{l}\text { No hemi. A } \\
\text { larger } \\
\text { gypsum } \\
\text { peak with } \\
\text { mainly } \\
\text { anhydrite. }\end{array}$ \\
\hline Tue, 3/11 & $\begin{array}{l}\text { ANH-11: Same as } \\
\text { ANH-10 but low- } \\
\text { cost operation. } \\
\text { Avg. ART } \\
\text { conditions: } \\
\text { baseline } \\
\text { temperature, } 23 \\
\text { wt } \% \text { solids, } 1.1 \mathrm{M} \\
\mathrm{Na} \text {, baseline } \mathrm{pH}\end{array}$ & $\begin{array}{l}\text { Ended testing with mechanism A2. The } \\
\text { process operated well. }\end{array}$ & $\begin{array}{l}\mathrm{T}-289 \\
\mathrm{~T}-291\end{array}$ & $\begin{array}{l}3.4 \\
4.2\end{array}$ & $\begin{array}{l}84 \\
79\end{array}$ & $\begin{array}{l}\text { Mostly fines } \\
\text { with very } \\
\text { few blocky } \\
\text { crystals. }\end{array}$ & $\begin{array}{l}\text { No hemi. } \\
\text { No gypsum } \\
\text { peak. All } \\
\text { anhydrite. }\end{array}$ \\
\hline Wed, 3/12 & $\begin{array}{l}\text { ANH-11: Using } \\
\text { mechanism B1 for } \\
\text { surface area } \\
\text { control. Avg. ART } \\
\text { conditions: } \\
\text { baseline } \\
\text { temperature and } \\
\mathrm{pH}, 23 \mathrm{wt} \% \\
\text { solids, } 1.1 \mathrm{M} \mathrm{Na} \text {. }\end{array}$ & $\begin{array}{l}\text { The liquid sulfite is quite a big lower in } \\
\text { the ART. Starting to lose anhydrite. } \\
\text { Using mechanism B1 for surface area } \\
\text { control. }\end{array}$ & $\begin{array}{l}\mathrm{T}-292 \\
\mathrm{~T}-294\end{array}$ & $\begin{array}{l}4.2 \\
5.9\end{array}$ & $\begin{array}{l}79 \\
71\end{array}$ & $\begin{array}{l}\text { T-292 } \\
\text { showed no } \\
\text { big crystals. } \\
\text { Stacked } \\
\text { platelet } \\
\text { type } \\
\text { crystals } \\
\text { that are } \\
\text { getting } \\
\text { bigger. T- } \\
294 \\
\text { showed a } \\
\text { few huge } \\
\text { crystals. }\end{array}$ & $\begin{array}{l}\text { T-292 no } \\
\text { hemi. No } \\
\text { gypsum } \\
\text { peak. All } \\
\text { anhydrite. } \\
\text { T-294 had } \\
\text { small } \\
\text { gypsum } \\
\text { peak. }\end{array}$ \\
\hline
\end{tabular}


Table B-1. Anhydrite Operations and Results Summary

\begin{tabular}{|c|c|c|c|c|c|c|c|}
\hline Date & $\begin{array}{c}\text { Test ID/ } \\
\text { Description }\end{array}$ & Operating/Results Summary & $\begin{array}{c}\text { Sample } \\
\text { ID }^{1}\end{array}$ & $\begin{array}{c}\text { Solid } \\
\text { Wt \% } \\
\text { Hydrate }\end{array}$ & $\begin{array}{c}\text { Est. } \\
\text { Wt \% } \\
\text { Anhydrite }\end{array}$ & $\begin{array}{c}\text { SEM } \\
\text { Description }\end{array}$ & $\begin{array}{c}\text { XRD } \\
\text { Description }\end{array}$ \\
\hline Thu, 3/13 & $\begin{array}{l}\text { ANH-11: Using } \\
\text { mechanism B1 for } \\
\text { surface area } \\
\text { control. Avg. ART } \\
\text { conditions: } \\
\text { baseline } \\
\text { temperature and } \\
\mathrm{pH}, 23 \text { wt } \% \\
\text { solids, } 1.1 \mathrm{M} \mathrm{Na} \text {. }\end{array}$ & $\begin{array}{l}\mathrm{O} 2 \text { measurements from } \mathrm{ART} \text { indicate } \\
\mathrm{O}: \mathrm{SO} 2 \text { ratio is } 1.4-1.8 \text {. Using } \\
\text { mechanism B1 for surface area control. }\end{array}$ & $\begin{array}{l}\mathrm{T}-295 \\
\mathrm{~T}-297\end{array}$ & $\begin{array}{l}6.6 \\
7.1\end{array}$ & $\begin{array}{l}68 \\
65\end{array}$ & $\begin{array}{l}\text { Stacked } \\
\text { platelet } \\
\text { type } \\
\text { crystals } \\
\text { with a few, } \\
\text { huge } \\
\text { crystals. } \\
\text { Some rod } \\
\text { like crystals } \\
\text { appearing. }\end{array}$ & $\begin{array}{l}\text { No hemi. } \\
\text { Huge } \\
\text { gypsum } \\
\text { peak. } \\
\text { Normal } \\
\text { anhydrite } \\
\text { peak. }\end{array}$ \\
\hline Fri, 3/14 & $\begin{array}{l}\text { ANH-11: Using } \\
\text { mechanism B2 for } \\
\text { surface area } \\
\text { control. Avg. ART } \\
\text { conditions: } \\
\text { baseline } \\
\text { temperature and } \\
\mathrm{pH}, 23 \text { wt } \% \\
\text { solids, } 1.1 \mathrm{M} \mathrm{Na} \text {. }\end{array}$ & $\begin{array}{l}\text { The scrubber was brought online to build } \\
\text { solids. Some additive } 1 \text { had to be added } \\
\text { to the ART to briefly maintain oxidation } \\
\text { reaction. Using mechanism B2 for } \\
\text { surface area control. }\end{array}$ & $\begin{array}{l}\mathrm{T}-298 \\
\mathrm{~T}-303\end{array}$ & $\begin{array}{l}6.8 \\
7.6\end{array}$ & $\begin{array}{l}67 \\
63\end{array}$ & $\begin{array}{l}\text { Stacked } \\
\text { platelet } \\
\text { type } \\
\text { crystals } \\
\text { with a few, } \\
\text { huge } \\
\text { crystals. } \\
\text { Some rod } \\
\text { like } \\
\text { crystals. } \\
\end{array}$ & $\begin{array}{l}\text { No hemi. } \\
\text { Huge } \\
\text { gypsum } \\
\text { peak. } \\
\text { Normal } \\
\text { anhydrite } \\
\text { peak. }\end{array}$ \\
\hline Sat, 3/15 & $\begin{array}{l}\text { ANH-11: Using } \\
\text { mechanism B3 for } \\
\text { surface area } \\
\text { control. Avg. ART } \\
\text { conditions: } \\
\text { baseline } \\
\text { temperature and } \\
\mathrm{pH}, 23 \text { wt } \% \\
\text { solids, } 1.1 \mathrm{M} \mathrm{Na} \text {. }\end{array}$ & $\begin{array}{l}\text { Began adding } 23 \mathrm{~kg}(50 \mathrm{lb}) \text { soda ash } \\
\text { every } 2 \text { hours to maintain removal } \\
\text { efficiency. Using mechanism B3 for } \\
\text { surface area control. }\end{array}$ & & & & & \\
\hline Sun, 3/16 & $\mathrm{ANH}-11$ & $\begin{array}{l}\text { Removal efficiency had decreased so } \\
\text { the FGDRT pH was increased to } 5.6 \text {. } \\
\text { Returning to mechanism B2 for surface } \\
\text { area control. }\end{array}$ & & & & & \\
\hline Mon, 3/17 & $\begin{array}{l}\text { ANH-13: Same as } \\
\text { ANH-11 but no } \\
\text { surface area } \\
\text { control. Avg. ART } \\
\text { conditions: } \\
\text { baseline } \\
\text { temperature, } 20 \\
\text { wt } \% \text { solids, } 1.1 \mathrm{M} \\
\mathrm{Na} \text {, baseline } \mathrm{pH} \text {. }\end{array}$ & $\begin{array}{l}\text { Solids have returned to previous state of } \\
\text { being "reactive." Not sure if this is } \\
\text { related to change in surface area control } \\
\text { mechanism, change in FGD operation, } \\
\text { or unknown factor. No surface area } \\
\text { control mechanism used.. }\end{array}$ & $\begin{array}{l}\text { T-306 } \\
\text { T-309 }\end{array}$ & $\begin{array}{l}3.7 \\
3.1\end{array}$ & $\begin{array}{l}82 \\
85\end{array}$ & $\begin{array}{l}\text { No huge } \\
\text { crystals. } \\
\text { Stacked } \\
\text { platelet } \\
\text { crystals are } \\
\text { smaller. } \\
\text { Some rod } \\
\text { type. }\end{array}$ & $\begin{array}{l}\text { No hemi. } \\
\text { Small } \\
\text { gypsum } \\
\text { peak. } \\
\text { Bigger } \\
\text { anhydrite } \\
\text { peak. }\end{array}$ \\
\hline Tue, 3/18 & $\begin{array}{l}\text { ANH-13: Same as } \\
\text { ANH-11 but no } \\
\text { surface area } \\
\text { control. Avg. ART } \\
\text { conditions: } \\
\text { baseline } \\
\text { temperature, } 20 \\
\text { wt } \% \text { solids, } 1.1 \mathrm{M} \\
\mathrm{Na} \text {, baseline } \mathrm{pH} \text {. }\end{array}$ & $\begin{array}{l}\text { Operational difficulties prevent using } \\
\text { surface area control mechanism. }\end{array}$ & $\begin{array}{l}\mathrm{T}-310 \\
\mathrm{~T}-311\end{array}$ & $\begin{array}{l}3.7 \\
3.8\end{array}$ & $\begin{array}{l}82 \\
82\end{array}$ & $\begin{array}{l}\text { A few large } \\
\text { crystals. } \\
\text { Stacked } \\
\text { platelet } \\
\text { crystals are } \\
\text { small. } \\
\text { Some rod } \\
\text { type. }\end{array}$ & $\begin{array}{l}\text { No hemi. } \\
\text { Slightly } \\
\text { bigger } \\
\text { gypsum } \\
\text { peak. } \\
\text { Mainly } \\
\text { anhydrite. }\end{array}$ \\
\hline
\end{tabular}


Table B-1. Anhydrite Operations and Results Summary

\begin{tabular}{|c|c|c|c|c|c|c|c|}
\hline Date & $\begin{array}{c}\text { Test ID/ } \\
\text { Description }\end{array}$ & Operating/Results Summary & $\begin{array}{l}\text { Sample } \\
\text { ID }^{1}\end{array}$ & $\begin{array}{c}\text { Solid } \\
\text { Wt \% } \\
\text { Hydrate }\end{array}$ & $\begin{array}{c}\text { Est. } \\
\text { Wt \% } \\
\text { Anhydrite }\end{array}$ & $\begin{array}{c}\text { SEM } \\
\text { Description }\end{array}$ & $\begin{array}{c}\text { XRD } \\
\text { Description }\end{array}$ \\
\hline Wed, 3/19 & $\begin{array}{l}\text { ANH-13: Same as } \\
\text { ANH-11 but no } \\
\text { surface area } \\
\text { control. Avg. ART } \\
\text { conditions: } \\
\text { baseline } \\
\text { temperature, } 20 \\
\text { wt \% solids, } 1.1 \mathrm{M} \\
\mathrm{Na} \text {, baseline } \mathrm{pH} \text {. } \\
\end{array}$ & $\begin{array}{l}\text { Operational difficulties prevent using } \\
\text { surface area control mechanism. }\end{array}$ & $\begin{array}{l}\mathrm{T}-312 \\
\mathrm{~T}-315\end{array}$ & $\begin{array}{l}3.8 \\
4.2\end{array}$ & $\begin{array}{l}81 \\
80\end{array}$ & & \\
\hline Thu, 3/20 & $\begin{array}{l}\text { ANH-13: Same as } \\
\text { ANH-11 but no } \\
\text { surface area } \\
\text { control. Avg. ART } \\
\text { conditions: } \\
\text { baseline } \\
\text { temperature, } 20 \\
\text { wt \% solids, } 1.1 \mathrm{M} \\
\mathrm{Na} \text {, baseline } \mathrm{pH}\end{array}$ & $\begin{array}{l}\text { The centrifuge product appearance } \\
\text { changed from wet-looking, dripping } \\
\text { solids to drier, sandy solids. }\end{array}$ & $\begin{array}{l}\mathrm{T}-316 \\
\mathrm{~T}-318\end{array}$ & $\begin{array}{l}4.5 \\
4.9\end{array}$ & $\begin{array}{l}78 \\
76\end{array}$ & & \\
\hline Fri, 3/21 & $\begin{array}{l}\text { ANH-13: Same as } \\
\text { ANH-11 but no } \\
\text { surface area } \\
\text { control. Avg. ART } \\
\text { conditions: } \\
\text { baseline } \\
\text { temperature, } 20 \\
\text { wt \% solids, } 1.1 \mathrm{M} \\
\mathrm{Na} \text {, baseline } \mathrm{pH} \\
\end{array}$ & $\begin{array}{l}\text { Started the scrubber. Due to reagent } \\
\text { addition problems, pH increased to } 6.1 \text {. } \\
\text { Centrifuge product still looks dry. Added } \\
45 \mathrm{~kg}(100 \mathrm{lb}) \text { additive } 2 \text { to FGRT. } \\
\text { Shortly after this addition, lost the ART } \\
\text { oxidation reaction so additive } 1 \text { was } \\
\text { added. Began using mechanism B4 for } \\
\text { surface area control.. }\end{array}$ & $\begin{array}{l}\mathrm{T}-319 \\
\mathrm{~T}-324\end{array}$ & $\begin{array}{l}6.6 \\
5.6\end{array}$ & $\begin{array}{l}68 \\
73\end{array}$ & & \\
\hline Sat,3/22 & $\begin{array}{l}\text { ANH-14: Using } \\
\text { mechanism B4 for } \\
\text { surface area } \\
\text { control. Avg. ART } \\
\text { conditions: } \\
\text { baseline } \\
\text { temperature and } \\
\mathrm{pH}, 23 \text { wt } \% \\
\text { solids, } 1.1 \mathrm{M} \mathrm{Na} \text {. }\end{array}$ & $\begin{array}{l}\text { Continue to use mechanism } \mathrm{B} 4 \text { for } \\
\text { surface area control in the reactor. } \mathrm{pH} \text { in } \\
\text { FGDRT maintained at } 5.65 \text { to improve } \\
\text { removal. }\end{array}$ & & & & & \\
\hline Mon, 3/24 & $\begin{array}{l}\text { ANH-14: Using } \\
\text { mechanism B4 for } \\
\text { surface area } \\
\text { control. Avg. ART } \\
\text { conditions: } \\
\text { baseline } \\
\text { temperature and } \\
\mathrm{pH}, 23 \text { wt } \% \\
\text { solids, } 1.1 \mathrm{M} \mathrm{Na} \text {. }\end{array}$ & $\begin{array}{l}\text { Continue to use mechanism B4 for } \\
\text { surface area control in the reactor. }\end{array}$ & $\begin{array}{l}\mathrm{T}-325 \\
\mathrm{~T}-327\end{array}$ & $\begin{array}{l}8.4 \\
6.9\end{array}$ & $\begin{array}{l}59 \\
66\end{array}$ & & \\
\hline Tue, 3/25 & $\begin{array}{l}\text { ANH-14: Using } \\
\text { mechanism B4 for } \\
\text { surface area } \\
\text { control. Avg. ART } \\
\text { conditions: } \\
\text { baseline } \\
\text { temperature and } \\
\text { pH, } 23 \text { wt } \% \\
\text { solids, } 1.1 \mathrm{M} \mathrm{Na} \text {. }\end{array}$ & $\begin{array}{l}\text { Seeded with process solids containing } \\
\text { about } 6 \% \text { hydrate. Ordered USG's CA- } \\
20-4 \text { filler which is a finely ground } \\
\text { insoluble anhydrite. } \mathrm{O}_{2} \text { measured at ART } \\
\text { exhaust indicates an } \mathrm{O}: \mathrm{SO}_{2} \text { of } 1.3-1.8 \text {. }\end{array}$ & $\begin{array}{l}\mathrm{T}-328 \\
\mathrm{~T}-330\end{array}$ & $\begin{array}{l}8.5 \\
9.4\end{array}$ & $\begin{array}{l}58 \\
54\end{array}$ & & \\
\hline
\end{tabular}


Table B-1. Anhydrite Operations and Results Summary

\begin{tabular}{|c|c|c|c|c|c|c|c|}
\hline Date & $\begin{array}{c}\text { Test ID/ } \\
\text { Description }\end{array}$ & Operating/Results Summary & $\begin{array}{l}\text { Sample } \\
\text { ID }^{1}\end{array}$ & $\begin{array}{c}\text { Solid } \\
\text { Wt \% } \\
\text { Hydrate }\end{array}$ & $\begin{array}{c}\text { Est. } \\
\text { Wt \% } \\
\text { Anhydrite } \\
\end{array}$ & $\begin{array}{c}\text { SEM } \\
\text { Description }\end{array}$ & $\begin{array}{c}\text { XRD } \\
\text { Description }\end{array}$ \\
\hline Wed, $3 / 26$ & $\begin{array}{l}\text { ANH-14: Using } \\
\text { mechanism B5 for } \\
\text { surface area } \\
\text { control. Avg. ART } \\
\text { conditions: } \\
\text { baseline } \\
\text { temperature and } \\
\mathrm{pH}, 23 \mathrm{wt} \% \\
\text { solids, } 1.1 \mathrm{M} \mathrm{Na} \text {. }\end{array}$ & $\begin{array}{l}\text { Using mechanism B5 for surface area } \\
\text { control in the reactor. }\end{array}$ & $\begin{array}{l}\mathrm{T}-331 \\
\mathrm{~T}-333\end{array}$ & $\begin{array}{l}11.5 \\
11.8\end{array}$ & $\begin{array}{l}44 \\
42\end{array}$ & & \\
\hline Thu, 3/27 & $\begin{array}{l}\text { ANH-14: Using } \\
\text { mechanism B5 for } \\
\text { surface area } \\
\text { control. Avg. ART } \\
\text { conditions: } \\
\text { baseline } \\
\text { temperature and } \\
\mathrm{pH}, 23 \mathrm{wt} \% \\
\text { solids, } 1.1 \mathrm{M} \mathrm{Na} \text {. }\end{array}$ & $\begin{array}{l}\text { Ended test ANH-14 when surface area } \\
\text { control mechanism C1 was started at } \\
\text { 19:00. The centrifuge product still looks } \\
\text { very dry. It hardens some but can easily } \\
\text { be broken apart. }\end{array}$ & $\begin{array}{l}\mathrm{T}-334 \\
\mathrm{~T}-336\end{array}$ & $\begin{array}{l}12.1 \\
13.7\end{array}$ & $\begin{array}{l}41 \\
33\end{array}$ & & \\
\hline Fri, 3/28 & $\begin{array}{l}\text { ANH-15: Using } \\
\text { mechanism C1. } \\
\text { Avg. ART } \\
\text { conditions: } \\
\text { baseline } \\
\text { temperature and } \\
\text { pH, } 25 \text { wt \% } \\
\text { solids, } 1.1 \mathrm{M} \mathrm{Na} \text {. }\end{array}$ & $\begin{array}{l}\text { Continued to use mechanism } \mathrm{C} 1 \text { for } \\
\text { surface area control, but also used } \\
\text { mechanism } \mathrm{C} 2 \text { at 13:00 for one time } \\
\text { only. Some trouble maintaining } \mathrm{pH} \text { after } \\
\text { starting scrubber so additive } 1 \text { was } \\
\text { added as necessary. }\end{array}$ & $\begin{array}{l}\mathrm{T}-337 \\
\mathrm{~T}-342\end{array}$ & $\begin{array}{l}12.0 \\
10.7\end{array}$ & $\begin{array}{l}42 \\
48\end{array}$ & & \\
\hline Sat, 3/29 & $\begin{array}{l}\text { ANH-15: Using } \\
\text { mechanism } \mathrm{C} 1 . \\
\text { Avg. ART } \\
\text { conditions: } \\
\text { baseline } \\
\text { temperature and } \\
\mathrm{pH}, 25 \mathrm{wt} \% \\
\text { solids, } 1.1 \mathrm{M} \mathrm{Na} \text {. }\end{array}$ & $\begin{array}{l}\text { Using mechanism } \mathrm{C} 1 \text { for surface area } \\
\text { control. Continued to add additive } 1 \text { with } \\
\text { air below } 90 \mathrm{Nm} 3 / \mathrm{h}(60 \mathrm{scfm}) \text {. }\end{array}$ & & & & & \\
\hline Sun, 3/30 & $\begin{array}{l}\text { ANH-15: Using } \\
\text { mechanism C1. } \\
\text { Avg. ART } \\
\text { conditions: } \\
\text { baseline } \\
\text { temperature and } \\
\mathrm{pH}, 25 \text { wt } \% \\
\text { solids, } 1.1 \mathrm{M} \mathrm{Na} \text {. }\end{array}$ & $\begin{array}{l}\text { Using mechanism } \mathrm{C} 1 \text { for surface area } \\
\text { control. Lost a coil at } 7: 30 \text {. When } \\
\text { restarted at } 15: 00 \text {, the } \mathrm{ART} \text { temperature } \\
\text { was at } 175^{\circ} \mathrm{F} \text {. It increased to } 179^{\circ} \mathrm{F} \text { by } \\
\text { midnight. }\end{array}$ & & & & & \\
\hline Mon, 3/31 & $\begin{array}{l}\text { ANH-15: Using } \\
\text { mechanism } \mathrm{C} 1 . \\
\text { Avg. ART } \\
\text { conditions: } \\
\text { baseline } \\
\text { temperature and } \\
\mathrm{pH}, 25 \mathrm{wt} \% \\
\text { solids, } 1.1 \mathrm{M} \mathrm{Na} \text {. }\end{array}$ & $\begin{array}{l}\text { ART temperature was about } 178^{\circ} \mathrm{F} \\
\text { during the morning but dropped to } 176^{\circ} \mathrm{F} \\
\text { while repairing a fitting. Lowered } \\
\text { oxidation air to } 60 \mathrm{Nm}^{3} / \mathrm{h}(40 \mathrm{scfm}) \text { to } \\
\text { increase temperature. Using mechanism } \\
\mathrm{C} 1 \text { for surface area control. }\end{array}$ & $\begin{array}{l}\mathrm{T}-343 \\
\mathrm{~T}-345\end{array}$ & $\begin{array}{l}14.5 \\
15.4\end{array}$ & $\begin{array}{l}25 \\
28\end{array}$ & & \\
\hline
\end{tabular}


Table B-1. Anhydrite Operations and Results Summary

\begin{tabular}{|c|c|c|c|c|c|c|c|}
\hline Date & $\begin{array}{c}\text { Test ID/ } \\
\text { Description }\end{array}$ & Operating/Results Summary & $\begin{array}{l}\text { Sample } \\
\text { ID }^{1}\end{array}$ & $\begin{array}{c}\text { Solid } \\
\text { Wt \% } \\
\text { Hydrate }\end{array}$ & $\begin{array}{c}\text { Est. } \\
\text { Wt \% } \\
\text { Anhydrite }\end{array}$ & $\begin{array}{c}\text { SEM } \\
\text { Description }\end{array}$ & $\begin{array}{c}\text { XRD } \\
\text { Description }\end{array}$ \\
\hline Tue, 4/1 & $\begin{array}{l}\text { ANH-15: Using } \\
\text { mechanism C1. } \\
\text { Avg. ART } \\
\text { conditions: } \\
\text { baseline } \\
\text { temperature and } \\
\text { pH, } 25 \text { wt \% } \\
\text { solids, } 1.1 \mathrm{M} \mathrm{Na} \text {. }\end{array}$ & $\begin{array}{l}\text { No surface area control mechanism } \\
\text { used (operator error). Lowered oxidation } \\
\text { air to } 45 \mathrm{Nm}^{3} / \mathrm{h} \text { (30 scfm) at 16:00. } \\
\text { Shortly after, heated tank out of service } \\
\text { until 22:00 due to leaks. }\end{array}$ & $\begin{array}{l}\mathrm{T}- \\
\mathrm{T}-\end{array}$ & $\begin{array}{l}14.7 \\
15.6\end{array}$ & $\begin{array}{l}28 \\
24\end{array}$ & & \\
\hline Wed, 4/2 & $\begin{array}{l}\text { ANH-15: Using } \\
\text { mechanism C1. } \\
\text { Avg. ART } \\
\text { conditions: } \\
\text { baseline } \\
\text { temperature and } \\
\text { pH, } 25 \text { wt \% } \\
\text { solids, } 1.1 \mathrm{M} \mathrm{Na} \text {. }\end{array}$ & $\begin{array}{l}\text { The ART pH increased to } 2.5 \text { units } \\
\text { above baseline due to loss of additive } 1 . \\
\text { Fixed this problem and maintained air at } \\
\left.653 \mathrm{Nm}^{3} / \mathrm{h} \text { ( } 35 \mathrm{scfm}\right) \text {. Using mechanism } \\
\mathrm{C} 1 \text { for surface area control. }\end{array}$ & $\begin{array}{l}\mathrm{T}- \\
\mathrm{T}-\end{array}$ & $\begin{array}{l}15.8 \\
16.6\end{array}$ & $\begin{array}{l}23 \\
19\end{array}$ & & \\
\hline Thu, 4/3 & $\begin{array}{l}\text { ANH-16: Addition } \\
\text { of additive } 2\end{array}$ & $\begin{array}{l}\text { Increased oxidation air to } 60 \mathrm{Nm}^{3} / \mathrm{h}(40 \\
\mathrm{scfm}) \text { at } 9: 30 \text { and started adding } 11 \mathrm{~kg} \\
(25 \mathrm{lb}) \text { additive } 2 \text { to ART. Added } 2.2 \mathrm{~kg} \text { ( } 5 \\
\text { lb) every half hour. Shortly after first } \\
\text { addition, additive } 1 \text { was not required to } \\
\text { maintain } \mathrm{pH} \text {. }\end{array}$ & $\begin{array}{l}\mathrm{T}- \\
\mathrm{T}-\end{array}$ & $\begin{array}{l}14.1 \\
15.2\end{array}$ & $\begin{array}{l}31 \\
26\end{array}$ & & \\
\hline Fri, 4/4 & $\begin{array}{l}\text { ANH-18: } \\
\text { Mechanism C3. } \\
\text { Avg. ART } \\
\text { conditions: } \\
\text { Baseline } \\
\text { temperature and } \\
\text { pH,18 wt \% } \\
\text { solids, } 1.0 \mathrm{M} \mathrm{Na} \text {. }\end{array}$ & $\begin{array}{l}\text { Using mechanism C2 for surface area } \\
\text { control. First day of two additions. Added } \\
150 \text { ppm additive } 2 \text { to ART and } 1000 \\
\text { ppm to FGDRT. No additive } 1 \text { required } \\
\text { to control ART pH since adding additive } \\
2 \text { yesterday. pH remains below baseline } \\
\text { with air less than } 60 \mathrm{Nm}^{3} / \mathrm{h} \text { ( } 40 \text { scfm). } \\
\text { Seems that solids are changing. }\end{array}$ & $\begin{array}{l}\text { T-359 } \\
\text { T-363 }\end{array}$ & $\begin{array}{l}12.8 \\
13.2\end{array}$ & $\begin{array}{l}37 \\
36\end{array}$ & & \\
\hline Sun, 4/6 & $\begin{array}{l}\text { ANH-18: Avg. } \\
\text { ART conditions: } \\
\text { Baseline } \\
\text { temperature and } \\
\mathrm{pH}, 18 \text { wt } \% \\
\text { solids, } 1.0 \mathrm{M} \mathrm{Na} \text {. }\end{array}$ & $\begin{array}{l}\text { Using mechanism C2 for surface area } \\
\text { control. Ran out of soda ash--had been } \\
\text { adding } 11 \mathrm{~kg}(25 \mathrm{lb}) \text { per hour and started } \\
\text { adding sodium sulfite. }\end{array}$ & T-367 & 2.3 & 89 & & \\
\hline Mon, 4/7 & $\begin{array}{l}\text { ANH-18: Avg. } \\
\text { ART conditions: } \\
\text { Baseline } \\
\text { temperature and } \\
\mathrm{pH}, 18 \text { wt } \% \\
\text { solids, } 1.0 \mathrm{M} \mathrm{Na} \text {. }\end{array}$ & $\begin{array}{l}\text { Using mechanism } \mathrm{C} 2 \text { for surface area } \\
\text { control. }\end{array}$ & $\begin{array}{l}\text { T-365 } \\
\text { T-369 }\end{array}$ & $\begin{array}{l}3.7 \\
4.0\end{array}$ & $\begin{array}{l}82 \\
81\end{array}$ & & \\
\hline Tue, $4 / 8$ & $\begin{array}{l}\text { ANH-18: Avg. } \\
\text { ART conditions: } \\
\text { Baseline } \\
\text { temperature and } \\
\mathrm{pH}, 18 \mathrm{wt} \% \\
\text { solids, } 1.0 \mathrm{M} \mathrm{Na}\end{array}$ & $\begin{array}{l}\text { Using mechanism C2 for surface area } \\
\text { control. Under microscope, crystals } \\
\text { show small anhydrite crystals. The ART } \\
\text { feed slurry pH has been lower over the } \\
\text { past few days. }\end{array}$ & $\begin{array}{l}\text { T-371 } \\
\text { T-373 }\end{array}$ & $\begin{array}{l}2.1 \\
2.5\end{array}$ & $\begin{array}{l}90 \\
88\end{array}$ & & \\
\hline Wed, 4/9 & $\begin{array}{l}\text { ANH-19: Avg. } \\
\text {.ART conditions: } \\
\text { baseline } \\
\text { temperature and } \\
\mathrm{pH}, 18 \text { wt } \% \\
\text { solids, } 1.0 \mathrm{M} \mathrm{Na} \text {. }\end{array}$ & $\begin{array}{l}\text { Switched to mechanism C5 for surface } \\
\text { area control to start new test. }\end{array}$ & $\begin{array}{l}\text { T-375 } \\
\text { T-377 }\end{array}$ & $\begin{array}{l}1.2 \\
1.0\end{array}$ & $\begin{array}{l}94 \\
95\end{array}$ & & \\
\hline
\end{tabular}


Table B-1. Anhydrite Operations and Results Summary

\begin{tabular}{|c|c|c|c|c|c|c|c|}
\hline Date & $\begin{array}{c}\text { Test ID/ } \\
\text { Description }\end{array}$ & Operating/Results Summary & $\begin{array}{c}\text { Sample } \\
\text { ID }^{1}\end{array}$ & $\begin{array}{c}\text { Solid } \\
\text { Wt \% } \\
\text { Hydrate }\end{array}$ & $\begin{array}{c}\text { Est. } \\
\text { Wt \% } \\
\text { Anhydrite } \\
\end{array}$ & $\begin{array}{c}\text { SEM } \\
\text { Description }\end{array}$ & $\begin{array}{c}\text { XRD } \\
\text { Description }\end{array}$ \\
\hline Thu, 4/10 & $\begin{array}{l}\text { ANH-19: Avg. } \\
\text {.ART conditions: } \\
\text { baseline } \\
\text { temperature and } \\
\text { pH, } 18 \text { wt } \% \\
\text { solids, } 1.0 \mathrm{M} \mathrm{Na}\end{array}$ & $\begin{array}{l}\text { The heated tank was taken out of } \\
\text { service to repair a leak on the coil. } \\
\text { Continue to use mechanism C5 for } \\
\text { surface area control. }\end{array}$ & T-379 & 1.1 & 94 & & \\
\hline Fri, 4/11 & $\begin{array}{l}\text { ANH-19: Avg. } \\
\text { ART conditions: } \\
\text { baseline } \\
\text { temperature and } \\
\mathrm{pH}, 18 \text { wt } \% \\
\text { solids, } 1.0 \mathrm{M} \mathrm{Na}\end{array}$ & $\begin{array}{l}\text { FGD scrubber was brought on-line to } \\
\text { build solids in the FGDRT over the } \\
\text { weekend. Ended test with mechanism } \\
\text { C5 after second set of samples was } \\
\text { taken. Began returning centrate back to } \\
\text { the ART to lower the solids } \\
\text { concentration (residence time) over the } \\
\text { weekend. With this change, the surface } \\
\text { area control mechanism was also } \\
\text { changed to mechanism C6. }\end{array}$ & $\begin{array}{l}\mathrm{T}-382 \\
\mathrm{~T}-386\end{array}$ & $\begin{array}{l}1.2 \\
1.5\end{array}$ & $\begin{array}{l}94 \\
93\end{array}$ & & \\
\hline Sat,4/12 & $\begin{array}{l}\text { ANH-20: Low } \\
\text { solids } \\
\text { concentration, 30- } \\
\text { hr residence time. }\end{array}$ & $\begin{array}{l}\text { Continued to use mechanism C6. Solids } \\
\text { concentration was still a little high at } \\
16.7 \text { wt \%. Continued to feed centrate } \\
\text { back to the ART. }\end{array}$ & T-390 & 2.7 & 87 & & \\
\hline Mon, 4/14 & $\begin{array}{l}\text { ANH-20: } 30-\mathrm{hr} \\
\text { residence time. } \\
\text { Avg. .ART } \\
\text { conditions: } \\
\text { baseline } \\
\text { temperature and } \\
\text { pH, } 15 \text { wt } \% \\
\text { solids, } 1.1 \mathrm{M} \mathrm{Na} \text {. }\end{array}$ & $\begin{array}{l}\text { Solids concentration in the reaction tank } \\
\text { was down to } 13 \mathrm{wt} \% \text { and continued to } \\
\text { use mechanism } 66 \text {. }\end{array}$ & $\begin{array}{l}\text { T-388 } \\
\text { T-392 }\end{array}$ & $\begin{array}{c}9.5 \\
11.5\end{array}$ & $\begin{array}{l}53 \\
44\end{array}$ & & \\
\hline Tue, 4/15 & $\begin{array}{l}\text { ANH-20: } 30-\mathrm{hr} \\
\text { residence time. } \\
\text { Avg. .ART } \\
\text { conditions: } \\
\text { baseline } \\
\text { temperature and } \\
\mathrm{pH}, 15 \text { wt } \% \\
\text { solids, } 1.1 \mathrm{M} \mathrm{Na} \text {. }\end{array}$ & $\begin{array}{l}\text { Switched to mechanism C4 for surface } \\
\text { area control. By } 22: 00 \text {, the surface area } \\
\text { control mechanism was switched to } \\
\text { mechanism AC1. The solids } \\
\text { concentration in the ART averaged } \\
\text { about } 14 \text { wt } \% \text {. }\end{array}$ & $\begin{array}{l}\text { T-394 } \\
\text { T-396 }\end{array}$ & $\begin{array}{l}13.2 \\
14.8\end{array}$ & $\begin{array}{l}36 \\
28\end{array}$ & & \\
\hline Wed, 4/16 & $\begin{array}{l}\text { ANH-20: } 30-\mathrm{hr} \\
\text { residence time. } \\
\text { Avg. .ART } \\
\text { conditions: } \\
\text { baseline } \\
\text { temperature and } \\
\mathrm{pH}, 15 \text { wt } \% \\
\text { solids, } 1.1 \mathrm{M} \mathrm{Na} \text {. }\end{array}$ & $\begin{array}{l}\text { With no improvement in the anhydrite } \\
\text { concentration overnight, the centrate } \\
\text { return to the ART was stopped to see if } \\
\text { the fine gypsum being returned to the } \\
\text { tank was the cause. By afternoon, the } \\
\text { anhydrite was still low. The test was } \\
\text { ended by raising the solids concentration } \\
\text { in the ART. }\end{array}$ & $\begin{array}{l}\mathrm{T}-398 \\
\mathrm{~T}-401\end{array}$ & $\begin{array}{l}16.2 \\
16.6\end{array}$ & $\begin{array}{l}21 \\
19\end{array}$ & & \\
\hline Thu, $4 / 17$ & $\begin{array}{l}\text { ANH-21: Return } \\
\text { to high solids } \\
\text { conc. conditions. }\end{array}$ & $\begin{array}{l}\text { Continued to use mechanism AC1 for } \\
\text { surface area control while keeping the } \\
\text { solids concentration at } 20 \mathrm{wt} \% \text {. }\end{array}$ & $\begin{array}{l}\text { T-403 } \\
\text { T-405 }\end{array}$ & $\begin{array}{l}15.8 \\
14.0\end{array}$ & $\begin{array}{l}23 \\
32\end{array}$ & & \\
\hline Fri, 4/18 & $\begin{array}{l}\text { ANH-21: Avg. } \\
\text {.ART conditions: } \\
\text { baseline } \\
\text { temperature and } \\
\mathrm{pH}, 18 \text { wt } \% \\
\text { solids, } 1.1 \mathrm{M} \mathrm{Na} \text {. }\end{array}$ & $\begin{array}{l}\text { The FGD scrubber was started up early } \\
\text { in the morning to begin building solids in } \\
\text { the FGDRT. The solids appeared to be } \\
\text { improving throughout the day. }\end{array}$ & $\begin{array}{l}\mathrm{T}-407 \\
\mathrm{~T}-411\end{array}$ & $\begin{array}{l}13.7 \\
10.4\end{array}$ & $\begin{array}{l}33 \\
49\end{array}$ & & \\
\hline
\end{tabular}

B-16 
Table B-1. Anhydrite Operations and Results Summary

\begin{tabular}{|c|c|c|c|c|c|c|c|}
\hline Date & $\begin{array}{c}\text { Test ID/ } \\
\text { Description }\end{array}$ & Operating/Results Summary & $\begin{array}{l}\text { Sample } \\
\text { ID }^{1}\end{array}$ & $\begin{array}{l}\text { Solid } \\
\text { Wt \% } \\
\text { Hydrate }\end{array}$ & $\begin{array}{c}\text { Est. } \\
\text { Wt \% } \\
\text { Anhydrite }\end{array}$ & $\begin{array}{l}\text { SEM } \\
\text { Description }\end{array}$ & $\begin{array}{c}\text { XRD } \\
\text { Description }\end{array}$ \\
\hline Sat, 4/19 & $\begin{array}{l}\text { ANH-21: Avg. } \\
\text { ART conditions: } \\
\text { baseline } \\
\text { temperature and } \\
\mathrm{pH}, 18 \text { wt } \% \\
\text { solids, } 1.1 \mathrm{M} \mathrm{Na} \text {. }\end{array}$ & $\begin{array}{l}\text { Switched back to mechanism C4 for } \\
\text { surface area control anticipating an } \\
\text { improvement in the solids condition. }\end{array}$ & & & & & \\
\hline Sun, 4/20 & $\begin{array}{l}\text { ANH-21: Avg. } \\
\text {.ART conditions: } \\
\text { baseline } \\
\text { temperature and } \\
\mathrm{pH}, 18 \text { wt } \% \\
\text { solids, } 1.1 \mathrm{M} \mathrm{Na} \text {. }\end{array}$ & $\begin{array}{l}\text { The surface area control mechanism } \\
\text { was switched from C4 to C7 due to } \\
\text { operational problems in the morning. }\end{array}$ & & & & & \\
\hline Mon, 4/21 & $\begin{array}{l}\text { ANH-21: Avg. } \\
\text {.ART conditions: } \\
\text { baseline } \\
\text { temperature and } \\
\mathrm{pH}, 18 \mathrm{wt} \% \\
\text { solids, } 1.1 \mathrm{M} \mathrm{Na} \text {. }\end{array}$ & $\begin{array}{l}\text { The FGD scrubber was taken out of } \\
\text { service early in the morning after } \\
\text { building level to } 5 \mathrm{~m} \text { (17 ft). At 16:00, } \\
\text { the surface area control mechanism was } \\
\text { switched from C7 to A3 due to } \\
\text { operational problems. }\end{array}$ & $\begin{array}{l}\mathrm{T}-413 \\
\mathrm{~T}-415\end{array}$ & $\begin{array}{l}0.8 \\
0.5\end{array}$ & $\begin{array}{l}96 \\
98\end{array}$ & & \\
\hline Tue, 4/22 & $\begin{array}{l}\text { ANH-21: Avg. } \\
\text {.ART conditions: } \\
\text { baseline } \\
\text { temperature and } \\
\mathrm{pH}, 18 \text { wt } \% \\
\text { solids, } 1.1 \mathrm{M} \mathrm{Na} \text {. }\end{array}$ & $\begin{array}{l}\text { After the afternoon samples were taken, } \\
\text { the flow to the heated tank was stopped } \\
\text { to allow the temperature in the ART to } \\
\text { drop to } 1^{\circ} \mathrm{C}\left(3^{\circ} \mathrm{F}\right) \text { below baseline for the } \\
\text { next test. }\end{array}$ & $\begin{array}{l}\mathrm{T}-417 \\
\mathrm{~T}-419\end{array}$ & 0.9 & 96 & & \\
\hline Wed, 4/23 & $\begin{array}{l}\text { ANH-22: Low } \\
\text { temperature } \\
\text { operation. Avg. } \\
\text { ART conditions: } \\
1^{\circ} \mathrm{C}\left(3^{\circ} \mathrm{F}\right) \text { below } \\
\text { baseline, } 18 \text { wt \% } \\
\text { solids, } 1.0 \mathrm{M} \mathrm{Na} \text {, } \\
\text { baseline } \mathrm{pH} \text {. }\end{array}$ & $\begin{array}{l}\text { Continued to use mechanism } \mathrm{A} 3 \text { for } \\
\text { surface area control. The temperature in } \\
\text { the ART was maintained at } 1^{\circ} \mathrm{C}\left(3^{\circ} \mathrm{F}\right) \\
\text { below baseline. }\end{array}$ & $\begin{array}{l}\mathrm{T}-421 \\
\mathrm{~T}-423\end{array}$ & $\begin{array}{l}0.8 \\
0.4\end{array}$ & $\begin{array}{l}96 \\
98\end{array}$ & & \\
\hline Thu, 4/24 & $\begin{array}{l}\text { ANH-23: } \\
\text { Mechanism D2. } \\
\text { Avg. ART } \\
\text { conditions: } \\
\text { baseline } \\
\text { temperature and } \\
\text { pH, } 20 \text { wt \% } \\
\text { solids, } 0.9 \mathrm{M} \mathrm{Na} \text {. }\end{array}$ & $\begin{array}{l}\text { Used mechanism C7 during the morning } \\
\text { instead of mechanism A3 for surface } \\
\text { area control. At noon, used mechanism } \\
\text { D1 for one time only then switched to } \\
\text { mechanism D2 for remainder of day }\end{array}$ & $\begin{array}{l}\mathrm{T}-425 \\
\mathrm{~T}-427\end{array}$ & $\begin{array}{l}0.6 \\
0.9\end{array}$ & $\begin{array}{l}96 \\
96\end{array}$ & & \\
\hline Fri, 4/25 & $\begin{array}{l}\text { ANH-23: Avg. } \\
\text { ART conditions: } \\
\text { baseline } \\
\text { temperature and } \\
\mathrm{pH}, 20 \text { wt \% } \\
\text { solids, } 0.9 \mathrm{M} \mathrm{Na} \text {. }\end{array}$ & $\begin{array}{l}\text { At 16:00 the surface area control } \\
\text { mechanism was switched from D2 to D3. }\end{array}$ & $\begin{array}{l}\text { T-429 } \\
\text { T-432 }\end{array}$ & $\begin{array}{l}1.0 \\
1.1\end{array}$ & $\begin{array}{l}95 \\
95\end{array}$ & & \\
\hline $\begin{array}{l}\text { Sat-Sun, } \\
4 / 28,4 / 29\end{array}$ & $\begin{array}{l}\text { ANH-23: Avg. } \\
\text { ART conditions: } \\
\text { baseline } \\
\text { temperature and } \\
\mathrm{pH}, 20 \text { wt } \% \\
\text { solids, } 0.9 \mathrm{M} \mathrm{Na} \text {. }\end{array}$ & $\begin{array}{l}\text { The FGD scrubber was brought on-line } \\
\text { at 5:00. All soda ash was depleted at } \\
\text { this time and the sodium concentration } \\
\text { was expected to decrease over the next } \\
\text { few days. The scrubber was taken out } \\
\text { of service on Sunday at noon. }\end{array}$ & & & & & \\
\hline
\end{tabular}


Table B-1. Anhydrite Operations and Results Summary

\begin{tabular}{|c|c|c|c|c|c|c|c|}
\hline Date & $\begin{array}{c}\text { Test ID/ } \\
\text { Description }\end{array}$ & Operating/Results Summary & $\begin{array}{c}\text { Sample } \\
\text { ID }^{1}\end{array}$ & $\begin{array}{c}\text { Solid } \\
\text { Wt \% } \\
\text { Hydrate }\end{array}$ & $\begin{array}{c}\text { Est. } \\
\text { Wt \% } \\
\text { Anhydrite }\end{array}$ & $\begin{array}{c}\text { SEM } \\
\text { Description }\end{array}$ & $\begin{array}{c}\text { XRD } \\
\text { Description }\end{array}$ \\
\hline Mon, 4/28 & $\begin{array}{l}\text { ANH-23: Avg. } \\
\text { ART conditions: } \\
\text { baseline } \\
\text { temperature and } \\
\text { pH, } 20 \text { wt } \% \\
\text { solids, } 0.9 \mathrm{M} \mathrm{Na} \text {. }\end{array}$ & $\begin{array}{l}\text { Continue to use mechanism D3 for } \\
\text { surface area control. At } 23: 00 \text {, additive } \\
1 \text { addition was started to the ART to } \\
\text { lower pH to } 0.9 \mathrm{pH} \text { units below baseline } \\
\text { for ANH-24. }\end{array}$ & $\begin{array}{l}\mathrm{T}-434 \\
\mathrm{~T}-436\end{array}$ & $\begin{array}{l}0.4 \\
0.7\end{array}$ & $\begin{array}{l}98 \\
97\end{array}$ & & \\
\hline Tue, 4/29 & $\begin{array}{l}\text { ANH-24: } \\
\text { Mechanism D3, } \\
\text { low pH. Avg. ART } \\
\text { conditions: } \\
\text { baseline temp., } \\
23 \text { wt \% solids, } \\
0.8 \mathrm{M} \mathrm{Na}, 0.9 \mathrm{pH} \\
\text { units below } \\
\text { baseline. }\end{array}$ & $\begin{array}{l}\text { Continue to use mechanism D3 for } \\
\text { surface area control. }\end{array}$ & $\begin{array}{l}\mathrm{T}-438 \\
\mathrm{~T}-440\end{array}$ & $\begin{array}{l}0.9 \\
0.3\end{array}$ & $\begin{array}{l}96 \\
98\end{array}$ & & \\
\hline Wed, $4 / 30$ & $\begin{array}{l}\text { ANH-24: Avg. } \\
\text { ART conditions: } \\
\text { baseline temp., } \\
23 \text { wt \% solids, } \\
0.8 \mathrm{M} \mathrm{Na}, 0.9 \mathrm{pH} \\
\text { units below } \\
\text { baseline. }\end{array}$ & $\begin{array}{l}\text { The unit was taken of-line at } 13: 30 \text { to } \\
\text { end this portion of the test block. A } \\
\text { NYSEG outage was scheduled to begin } \\
\text { Friday, May } 2 \text { and run for approximately } \\
\text { two weeks. }\end{array}$ & $\begin{array}{l}\mathrm{T}-442 \\
\mathrm{~T}-444\end{array}$ & $\begin{array}{l}1.4 \\
2.7\end{array}$ & $\begin{array}{l}93 \\
87\end{array}$ & & \\
\hline
\end{tabular}

